\title{
уголовно-исполнительной системы
}

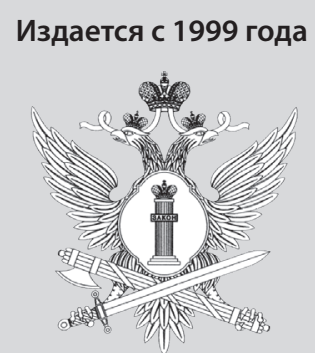

Издатель: ФКУ Объединенная редакция ФСИН России

Свидетельство о регистрации средства массовой информации № 019098 от 14 июля 1999 года

Журнал включен в Перечень рецензируемых научных изданий, в которых должны быть опубликованы основные научные результаты диссертаций на соискание ученой степени кандидата наук, на соискание ученой степени доктора наук, по научным специальностям и соответствующим им отраслям науки:

12.00.08 - Уголовное право и криминология; уголовноисполнительное право (юридические науки);

12.00.12 - Криминалистика; судебно-экспертная деятельность; оперативно-розыскная деятельность (юридические науки);

13.00.01 - Общая педагогика, история педагогики и образования (педагогические науки);

19.00.06 - Юридическая психология (психологические науки)

DOI 10.51522/2307-0382

Подписной индекс журнала 79288

(c) «Ведомости уголовно-

исполнительной системы». 2021

Начальник ФКУ Объединенная редакция ФСИН России - главный редактор

Шурлова Е. Е.

Редактор

Черешнева Л. А.

Ответственный секретарь

Сержантов Н. Ю.

Над журналом работали:

Анисифорова Т. А., Додонова Е. Ю., Пичугин И. А., Филимонова О.Н.

125130, г. Москва, ул. Нарвская, д. 15а Тел.: (495) 987-61-12

www.or.fsin.gov.ru

email: vedomosti.fsin@list.ru

Подписано в печать 31.05.2021. Бумага офсетная. Печать офсетная. Тираж 12444 экз. Заказ 866. Цена свободная.

Отпечатано ООО «Группа компаний МПФ» г. Москва

email: gkmpf@bk.ru

\section{Экспертный редакционный совет журнала «Ведомости уголовно-исполнительной системы»}

Шурлова Е. Е. начальник ФКУ Объединенная редакция ФСИН России Shurlova E. E. (председатель Экспертного редакционного совета) Head of the Joint Editorial Office of the FPS of Russia (Chairman of the Expert Editorial Board)

Агарков А. В. начальник кафедры оперативно-розыскной Agarkov A. V. деятельности юридического факультета ВЮИ ФСИН России, кандидат юридических наук, дочент

Chief of the Operative Investigative Activity Department of the VLI of the FPS of Russia, Candidate of Law, Associate Professor

Блинков О. Е. профессор кафедры гражданского права и прочесса Blinkov O. E. Академии ФСИН России, доктор юридических наук, npopeccop

Professor of the Department of Civil Law and Procedure of the Academy of the FPS of Russia, Doctor of Law, Professor

Вахнина В. В. профессор кафедры психологии, педагогики Vakhnina V. V. и организации работы с кадрами Академии управления МВД России, доктор психологических наук, дочент

Professor of the Department of Psychology, Pedagogy and Personnel Management of the Management Academy of the Ministry of the Interior of Russia, Doctor of Psychology, Associate Professor

Вилкова А. В. заместитель начальника ФКУ НИИ ФСИН России, Vilkova A. V. профессор Академии ФСИН России, доктор педагогических наук, дочент

Deputy Head of the Research Institute of the FPS of Russia, Professor of the Academy of the FPS of Russia, Doctor of Pedagogical Sciences, Associate Professor

Вотинов А. А. начальник ФКОУ ВО СЮИ ФСИН России, Votinov A. A. кандидат педагогических наук, дочент Head of SLI of the FPS of Russia, Candidate of Pedagogical Sciences, Associate Professor

Выхорь С. С. начальник ФКОУ ВО Воронежский институт Vykhor S. S. ФСИН России, кандидат исторических наук

Head of VRI of the FPS of Russia, Candidate of Historical Sciences

Гирько С. И. главный научный сотрудник НИЦ-1 ФКУНИИ Girko S. I ФСН России, доктор юридических наук, профессор, заслуженный деятель науки Российской Федерации

Chief Research Officer of the Research Center-1 of the Research Institute of the FPS of Russia, Doctor of Law, Professor, Honored Scholar of the Russian Federation 
Зауторова Э. В. профессор кафедры юридической психологии Zautorova E.V. и педагогики ВИПЭ ФСИН России, доктор педагогических наук, профессор Professor of the Department of Legal Psychology and Pedagogy of VILE of the FPS of Russia, Doctor of Pedagogical Sciences, Professor

Колотушкин С. М. главный научный сотрудник НИЦ-1 Kolotushkin S. М. ФКУНИИ ФСИН России, доктор юридических наук, профессор

Chief Research Officer of the Research Center-1 of the Research Institute of the FPS of Russia Honored Scholar of the Russian Federation, Doctor of Law, Professor

Кононец А. С. заведующий кафедрой пенитенциарной Kononets A.S. медицины ФГБОУВО МГМСУ

им. А. И. Евдокимова Минздрава России доктор медицинских наук, профеессор, заслуженный врач Российской Федерачии

Head of the Department of the Prison Medicine of FSBEI HE A. I. Yevdokimov MSMSU MOH Russia, Doctor of Medicine, Professor,

Honored Doctor of the Russian Federation

Кузнецова А.С. дочент кафедры пенитенциарной медицины Kuznetsova A. S. ФГБОУВО МГМСУ им. А.И. Евдокимова Минздрава России, кандидат медичинских наук, заслуженный врач Российской Федерачии

Assistant Professor of the Department of Prison Medicine FSBEI HE A. I. Yevdokimov MSMSU MOH Russia, Candidate of Medical Sciences, Honored Doctor of the Russian Federation

Кузьмин С. И. Kuzmin S.I. изучения отечественного и зарубежного опыта, истории уголовно-исполнительной системы, сравнительного анализа пенитенциарного законодательства ФКУНИИ ФСИН России, доктор юридических наук, профессор

Chief Research Officer of the Department for the Study of National and Foreign Experience, History of the Penal System, Comparative Analysis of the Penitentiary Legislation of the Research Institute of the FPS of Russia Doctor of Law, Professor

Лапшин В.Ф. начальник кафедры уголовного права

Lapshin V.F. Академии ФСИН России,

доктор юридических наук, дочент

Chief of the Criminal Law Department of the Academy of the FPS of Russia, Doctor of Law, Associate Professor

Лесников Г. Ю. главный научный сотрудник НИЦ-3

Lesnikov G.Yu. ФКУНИИ ФСИН России, доктор юридических наук, профессор

Chief Research Officer of the Research Center-3 of the Research Institute of the FPS of Russia, Doctor of Law, Professor

Марченко Н.Д. начальник ФКУНИИИТ ФСИН России

Marchenko N. D. Head of the Information Technologies Research Institute of the FPS of Russia

Нагорных Р. В. профессор кафедры административно-

Nagornykh R.v. правовых дисциплин ВИПЭ ФСИН России, доктор юридических наук, дочент

Professor of the Department of Administrative and Law Disciplines of VILE of the FPS of Russia, Doctor of Law, Associate Professor
Насреддинова К. А. начальник кафедры уголовного

Nasreddinova K. А. и уголовно-исполнительного права ФКОУ ВО СЮИ ФСИН России, кандидат юридических наук, доцент Chief of the Department of Criminal and Penal Law of SLI of the FPS of Russia, Candidate of Law, Associate Professor

Некрасов А. П. профессор кафедры профессиональных

Nekrasov A.P. дисциплин ФКОУ ВО СЮИ ФСИН России, доктор юридических наук, профессор

Professor of the Professional Disciplines Department of SLI of the FPS of Russia, Doctor of Law, Professor

Никитюк С. М. начальник Академии ФСИН России, Nikityuk S. M. кандидат юридических наук Head of the Academy of the FPS of Russia, Candidate of Law

Овчинников С. Н. заместитель начальника ФКУНИИ ФСИН

Ovchinnikov S. N. России, кандидат сочиологических наук

Deputy Head of the Research Institute of the FPS of Russia, Candidate of Sociological Sciences

Омелин В. Н. главный научный сотрудник НИЦ-3

Omelin V. N. ФКУНИИФСИН России, доктор юридических наук, профессор

Chief Research Officer of the Research Center-3 of the Research Institute of the FPS of Russia, Honored Scholar of the Russian Federation, Doctor of Law, Professor

Первозванский В. Б. кандидат юридических наук, Pervozvansky V. В. доцент

Candidate of Law, Associate Professor

Поздняков В. М. заместитель декана факультета

Pozdnyakov V. M. экстремальной психологии ФГБОУ ВО МГППУ,

доктор психологических наук, профессор, почетный сотрудник МВД России

Deputy Dean of the Faculty Extreme psychology of MSUPE, Doctor of Psychology, Professor, Honorary Officer of the Ministry of Internal Affairs of the Russian Federation

Полищук Н. И. профессор кафедры теории государства

Polishchuk N. I. и права, международного и европейского права Академии ФСИН России, доктор юридических наук, профессор

Professor of the Department of Theory of State and Law, International and European Law of the Academy of the FPS of Russia, Doctor of Law, Professor

Пономарев С. Б. главный научный сотрудник филиала

Ponomarev S. B. (2. Ижевск) ФКУНИИ ФСИН России, доктор медицинских наук, профессор, заслуженный врач Российской Федерачии

Chief Research Officer of the Izhevsk Branch of the Research Institute of the FPS of Russia Doctor of Medicine, Professor, Honored Doctor of the Russian Federation

Скиба А.П. начальник кафедры уголовно-

Skiba A. P. исполнительного права Академи ФСИН России, доктор юридических наук, дочент

Chief of the Penal Law Department of the Academy of the FPS of Russia, Doctor of Law, Associate Professor 
Smirnov A. M. отдела координации, организации и планирования научноисследовательской работь ФКУ НИИ ФСИН России доктор юридических наук, дочент

Chief Researcher of the Division of Research Coordination, Organization and Planning of the Research Institute of the FPS of Russia Doktor Habil in Law Associate Professor

Сорокин М. В. заместитель начальника кафедры Sorokin M.V. организации режима и надзора юридического факультета ВЮИ ФСИН России, кандидат юридических наук

Deputy Chief of the Regime and Supervision Department of the Law Faculty of VLI of the FPS of Russia Candidate of Law

Усеев P. 3. дочент кафедры режима и охраны Useev R.Z. в уголовно-исполнительной системе ФКОУ ВО СЮИ ФСИН России, кандидат юридических наук, дочент

Assistant Professor of the Department of the Regime and Guard in the Penal System of SLI of the FPS of Russia, Candidate of Law, Associate Professor

Уткин В. А. ведущий научный сотрудник Utkin V.A. отдела изучения отечественного и зарубежного опыта, истории уголовно-исполнительной системы, сравнительного анализа пенитенциарного законодательства ФКУНИИ ФСИН России, доктор юридических наук, профессор, заслуженный юрист Российской Федерации

Leading Research Officer of the Department for the Study of National and Foreign Experience, History of the Penal System, Comparative Analysis of the Penitentiary Legislation of the Research Institute of the FPS of Russia, Doctor of Law, Professor, Honored Lawyer of the Russian Federation

Харьковский Е. Л. начальник ВИПЭ ФСИН России, Kharkovsky E. L. кандидат юридических наук, дочент Head of VILE of the FPS of Russia, Candidate of Law, Associate Professor

Цветкова Н. А. ведущий научный сотрудник Tsvetkova N. A. отдела разработки методологий исполнения уголовных наказаний без лишения свободы НИЦ-2 ФКУ НИИ ФСИН России, доктор психологических наук, доцент Leading Research Officer of the Department for the Developmen of Non-custodial Sentences Methodologies of the Research Center-2 of the Research Institute of the FPS of Russia, Doctor of Psychology, Associate Professor

Яковлев К. Л.

профессор кафедры

государственного строительства и права Университета прокуратуры Российской Федерачии, доктор юридических наук, дочент старший советник юстиции Professor of the Department of State Construction and Law of the University of Prosecutor's office of the Russian Federation, Doctor of Law, Associate Professor, Senior Justice Adviser

\section{СОДЕРЖАНИЕ}

\section{ВЕДОМСТВЕННОЕ ОБРАЗОВАНИЕ И НАУКА}

Кузбасский институт ФСИН России 4

\section{В КУРСЕ СОБЫТИЙ}

Паршков А. В., Мадоян С. М., Чудакова С. Н. О работе

Х Международной недели творчества курсантов и студентов образовательных организаций ФСИН России «Виват, курсанты!», посвященной Дню работника уголовно-исполнительной системы Российской Федерации (Рязань, Академия ФСИН России,

22-26 марта 2021 г.).................................. 6

\section{НАУЧНЫЙ РАЗДЕЛ}

УГОЛОВНОЕ ПРАВО И КРИМИНОЛОГИЯ УГОЛОВНО-ИСПОЛНИТЕЛЬНОЕ ПРАВО

Трофимова Н. Н., Тимощук А. С. Хронодискретное моногеографическое сравнительное правоведение на примере уголовноисполнительной системы Российской Федерации . . . ....... 16

Федотова E. H. Современное состояние практики применения уголовного наказания в виде лишения свободы на определенный срок в отношении несовершеннолетних . . . . . . . . . . . 32

АДМИНИСТРАТИВНОЕ ПРАВО, АДМИНИСТРАТИВНЫЙ ПРОЦЕСС

Мошнякова Я. И, Корнилова Ю. А., Рябова Н. В., Козлов Ю.Д. Законодательное регулирование учета результатов научноисследовательских и опытно-конструкторских работ . . . . . . 45

ОБЩАЯ ПЕДАГОГИКА, ИСТОРИЯ ПЕДАГОГИКИ И ОБРАЗОВАНИЯ

Кириллова Т. В. Исправление осужденных путем переориентации их эмоционально-волевых качеств. 56

ЮРИДИЧЕСКАЯ ПСИХОЛОГИЯ

Силенков В. И., Первозванский В. Б. Социальнопсихологические факторы детерминации наркозависимого поведения несовершеннолетних осужденных и их учет в деятельности сотрудников воспитательной колонии...... 62

ЭКОНОМИКА И УПРАВЛЕНИЕ НАРОДНЫМ ХОЗЯЙСТВОМ

Черняев А. М. Участие исправительных учреждений в закупках, проводимых конкурентными способами, как инструмент поиска заказов для привлечения осужденных к труду . . . . . . . . . . . 72

На первой странице обложки: фото предоставлены пресс-службой Кузбасского института ФСИН России, коллаж Кривенко А. С. 


\section{Кузбасский институт ФСИН России}

И стория вуза берет свое начало 16 сентября 1999 года, когда Министром юстиции Российской Федерации был подписан приказ № 265 о создании в городе Новокузнецке Кузбасского филиала Владимирского юридического института Министерства юстиции Российской Федерации. Во многом это было связано с тем, что все вузы, занимавшиеся подготовкой кадров для уголовно-исполнительной системы, были расположены в европейской части страны, а территория от Урала до Дальнего Востока испытывала самый настоящий кадровый голод. Между тем управления пенитенциарной системы сибирских регионов - Красноярского, Забайкальского краев, Кемеровской, Новосибирской, Иркутской областей и других, давно были значительной частью уголовно-исполнительной системы страны, в Сибири располагалось большое количество исправительных учреждений.

Стратегически важное расположение филиала, а также активное и планомерное развитие послужили основанием для образования на его базе самостоятельного вуза. 25 декабря 2006 года распоряжением Правительства Российской Федерации № 1819-р был создан Кузбасский институт ФСИН России с филиалами в городах Томске и Уссурийске.

86 курсантов первого набора факультета очного обучения в 2008 году успешно окончили институт. Первый начальник института А. П. Полуэктов вспоминал об этом событии как об одном из главных в своей жизни.

В 2010 году институт возглавил кандидат педагогических наук, генерал-майор внутренней службы М. В. Киселев. С его приходом институт получил новый импульс в развитии. Был проведен большой объем работы по укреплению учебно-материальной базы института, улучшению социально-бытовых условий, организации ремонта зданий и сооружений.

15 мая 2014 года Кузбасскому институту было вручено знамя - официальный символ и реликвия подразделения, олицетворяющие его честь, доблесть, славу, традиции. Лучшие выпускники института с 2015 года участвуют в торжественном приеме Президента Российской Федерации в честь выпускников военных вузов в Кремле. В 2016 году делегацию выпускников образовательных организаций ФСИН России возглавил начальник института генерал-майор внутренней службы М. В. Киселев.

В августе 2019 года начальником Кузбасского института ФСИН России был назначен кандидат педагогических наук, доцент, полковник внутренней службы Анатолий Геннадьевич Чириков.

На сегодняшний день в вузе осуществляется подготовка по следующим специальностям и направлениям очной формы обучения:

специальность 40.05.02 «Правоохранительная деятельность» (программа специалитета) по специализации «Оперативно-розыскная деятельность», ведомственная специализация - «Оперативно-розыскная деятельность в УИС», по специализации «Воспитательно-правовая», ведомственная специализация - «Организация воспитательной работы с осужденными»;

направление подготовки 40.03.01 «Юриспруденция» (программа бакалавриата), направленность (профиль) уголовно-правовой, ведомственные специализации «Организация охраны и конвоирования в УИС», «Организация режима в УИС», «Организация деятельности уголовно-исполнительных инспекций»; 
по заочной форме обучения:

специальность 40.05.02 «Правоохранительная деятельность» (программа специалитета) по специализации «Обеспечение безопасности в уголовно-исполнительной системе», ведомственная специализация «Организация режима в УИС», по специализации «Воспитательно-правовая», ведомственная специализация - «Организация воспитательной работы с осужденными»;

специальность 44.05.01 «Педагогика и психология девиантного поведения» по специализации «Психолого-педагогическая коррекция и реабилитация лиц с девиантным поведением», ведомственная специализация - «Организация психолого-педагогической работы в УИС».

Юридическим факультетом реализуются направления подготовки (по договорам об оказании платных образовательных услуг):

- бакалавриат - направление подготовки 40.03.01 «Юриспруденция», профили подготовки - уголовно-правовой, гражданско-правовой;

- магистратура - направление подготовки 40.04.01 «Юриспруденция», магистерская программа - «Уголовное право, криминология, уголовно-исполнительное право».

В 2021 году на факультете правоохранительной деятельности обучаются 598 курсантов и 290 слушателей.

В целом по институту доля преподавателей, имеющих ученую степень и (или) звание, составляет 66 \% (52 человека); преподавателей, имеющих ученую степень доктора наук и (или) звание профессора, - 10 \% (8 человек).

Общая площадь зданий (помещений), принадлежащих институту, составляет 17 468,6 м², из них на учебно-лабораторную площадь приходится 11594 м². Спортивная площадка размещена на площади 10475 м², загородная учебная база - на 77271 м². $^{2}$

Со времени своего создания и по сегодняшний день Кузбасский институт
Федеральной службы исполнения наказаний является единственной за Уралом образовательной организацией высшего образования ФСИН России, которая за все время своего существования подготовила 6330 выпускников. Сегодня комплектующими для института являются 26 территориальных органов, занимающих две трети территории Российской Федерации.

Курсанты института являются получателями стипендии имени Г. Р. Державина и именной стипендии ФСИН России, занимают призовые места в научных мероприятиях различного уровня.

Институт ведет активную международную деятельность посредством двустороннего взаимодействия в области научных исследований. Заключены соглашения о сотрудничестве с ведущими российскими образовательными организациями высшего образования, в том числе МГУ имени М. В. Ломоносова.

В институте функционируют 6 творческих коллективов, которые регулярно становятся победителями и призерами мероприятий городского, областного и российского уровней.

Активно развивается спортивное направление: наиболее подготовленные курсанты осуществляют тренировочные занятия в группах спортивного совершенствования. Лучшие спортсмены по видам спорта (76 курсантов, 2 сотрудника) вошли в сборные команды института и приняли участие в соревнованиях, проводимых ФСИН России. Курсант 4 курса Абдулхалим Джаватханов входит в состав сборной ФСИН России по универсальному бою и неоднократно становился призером соревнований российского, европейского и мирового уровня.

Стоит отметить, что закрепляемость выпускников института составила $100 \%$, а удовлетворенность территориальных органов качеством подготовки выпускников $95 \% . \diamond$ 
DOI $10.51522 / 2307-0382-2021-229-6-6-15$

\section{А. В. ПАРШКОВ}

начальник научного центра Академии ФСИН России, кандидат юридических наук, полковник внутренней службы

Рязань

\section{ALEXANDER V. PARSHKOV}

Head of the Scientific Center of the Academy of the FPS of Russia, Candidate of Law Colonel of the Internal Service

Ryazan

\section{С. М. МАДОЯН}

заместитель начальника организационно-научного отдела научного центра

Академии ФСИН России, майор внутренней службы

Рязань

\section{SMBAT M. MADOYAN}

Deputy head of the Organizational and Scientific Department of the Scientific Center of the Academy of the FPS of Russia, Major of the Internal Service

Ryazan

\section{С. Н. ЧУДАКОВА}

начальник организационно-научного отдела научного центра Академии ФСИН России, кандидат юридических наук, майор внутренней службы

Рязань

\section{SVETLANA N. CHUDAKOVA}

Head of the Organizational and Scientific Department of the Scientific Center of the Academy of the FPS of Russia, Candidate of Law, Major of the Internal Service

Ryazan 


\section{О работе X Международной недели творчества курсантов и студентов образовательных организаций ФСИН России «Виват, курсанты!», посвященной Дню работника уголовно-исполнительной системы Российской Федерации}

\section{(Рязань, Академия ФСИН России, 22-26 марта 2021 г.)}

On the work of the X International week of creativity of cadets and students of educational organizations of the Federal Penitentiary Service of Russia «Vivat, cadets!», Dedicated to the Day of the employee of the penal system of the Russian Federation (Ryazan, Academy of the FPS of Russia, March 22-26, 2021)

Аннотация. В марте 2021 года в Академии ФСИН России состоялась юбилейная Х Международная неделя творчества курсантов и студентов образовательных организаций Федеральной службы исполнения наказаний «Виват, курсанты!». Это ярчайшее событие в жизни вуза было представлено многоуровневым комплексом интересных и насыщенных мероприятий научного, спортивного, творческого и культурного характера, в рамках которых открывались молодые таланты, развивались научные и творческие компетенции обучающихся, происходил обмен ценным опытом, в том числе на международном уровне.

Ключевые слова: неделя творчества, образовательные организации, Федеральная служба исполнения наказаний, курсанты, студенты, научные мероприятия, воспитательная работа, творчество.
Abstract. In March 2021, the Jubilee X International Week of Creativity of Cadets and Students of Educational Organizations of the Federal Penitentiary Service «Vivat, cadets!» was held at the Academy of the Federal Penitentiary Service of Russia. This brightest event in the life of the university was represented by a multi-level complex of interesting and rich events of scientific, sports, creative and cultural nature, within the framework of which young talents were discovered, scientific and creative competencies of students were developed, and valuable experience was exchanged, including at the international level.

Key words: week of creativity, educational organizations, the Federal Penitentiary Service, cadets, students, scientific events, educational work, creativity. 

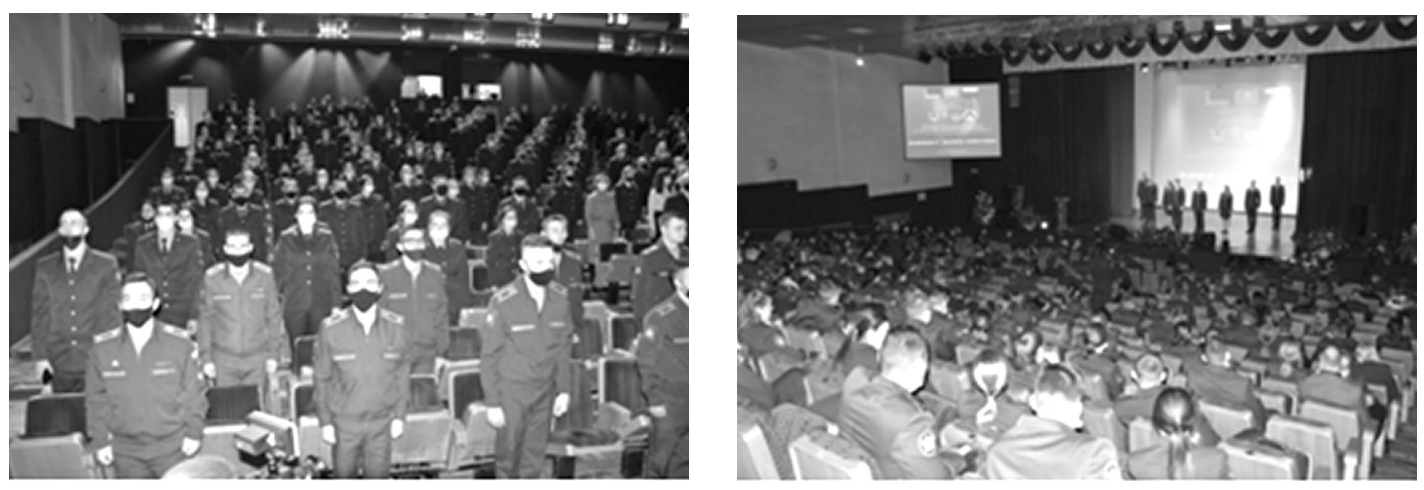

Участники Недели творчества

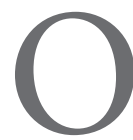

рганизация и проведение мероприятий научного, спортивного и творческого характера является одним из способов коммуникации среди обучающихся образовательных организаций Федеральной службы исполнения наказаний (ФСИН России) с ярко выраженной установкой на межличностное общение и разнообразные формы взаимодействия.

2021 год стал юбилейным для Международной недели творчества курсантов и студентов образовательных организаций ФСИН России «Виват, курсанты!» (далее Неделя творчества). В этом году уже в десятый раз она проводилась в стенах Академии ФСИН России с 22 по 26 марта и по традиции была приурочена к празднованию Дня работника уголовно-исполнительной системы Российской Федерации (далее также - УИС).

Без преувеличения Неделю творчества можно назвать фестивалем национальных культур и дружбы, который представлен ярким калейдоскопом разноплановых и насыщенных мероприятий. Сегодня Неделя творчества - это бренд Академии ФСИН России с четко выстроенной стратегией развития и позиционирования, а также просчитанными механизмами повышения осведомленности и формирования лояльности у целевой аудитории.
В этом году Неделя творчества объединила свыше 300 курсантов, студентов, адъюнктов, аспирантов и соискателей Академии ФСИН России, Владимирского юридического института ФСИН России, Пермского института ФСИН России, Самарского юридического института ФСИН России, Военного университета Министерства обороны Российской Федерации, Вологодского института права и экономики ФСИН России, Воронежского института ФСИН России, Кузбасского института ФСИН России, Псковского филиала Академии ФСИН России, Московского областного филиала Московского университета МВД России имени В. Я. Кикотя, Рязанского филиала Московского университета МВД России имени В. Я. Кикотя, Рязанского государственного агротехнологического университета имени П. А. Костычева, Рязанского государственного медицинского университета имени академика И. П. Павлова, Рязанского государственного университета имени С. А. Есенина и других образовательных организаций.

Данное мероприятие позволяет его участникам представлять свои идеи, демонстрировать достижения и успехи в той или иной сфере деятельности, знакомиться с идеями и взглядами других участников и, конечно же, получить профессиональную оценку проделанной работы. 
И самое главное, что Неделя творчества для ее участников - это прекрасный шанс с головой окунуться в праздничную и соревновательную атмосферу, узнать для себя много нового, познакомиться с интересными людьми.

Проведение мероприятий такого уровня - сложный и очень ответственный процесс, что обусловлено участием иностранных представителей, большим количеством гостей и участников, значительными затратами времени и иных ресурсов.

Организаторами Недели творчества в этом году по традиции выступили Федеральная служба исполнения наказаний, Академия ФСИН России, Уполномоченный по правам человека в Российской Федерации, Федеральное агентство по делам молодежи, Ассоциация юристов России, Молодежный Союз Экономистов и Финансистов, Совет молодых ученых и специалистов Рязанской области. В этом году в числе соорганизаторов Недели творчества впервые выступил Уполномоченный при Президенте Российской Федерации по правам ребенка.

Нельзя не отметить и тот факт, что мероприятия Недели творчества прошли при непосредственном участии Министерства образования и молодежной политики Рязанской области, Министерства физической культуры и спорта Рязанской области, Координационной службы Совета командующих Пограничными войсками государств - участников СНГ.

Международный статус Неделе творчества придало участие в дистанционном формате представителей Академии МВД Республики Беларусь, Могилевского института МВД Республики Беларусь, Костанайской академии МВД Республики Казахстан имени Шракбека Кабылбаева и Карагандинской академии МВД Республики Казахстан имени Баримбека Бейсенова, которые являются давними партнерами Академии ФСИН России.

С учетом ограничений, направленных на недопущение распространения в Российской Федерации новой короновирусной инфекции (COVID-19), в этом году мероприятия Недели творчества проходили как в очном, так и в дистанционном формате, однако это ни в коей мере не отразилось на их количестве и качестве. Круг участников и степень их подготовки позволили провести все запланированные в рамках Недели творчества мероприятия на высоком уровне.

Организаторы Недели творчества подготовили широкий комплекс интереснейших и неординарных мероприятий.

На открытии Недели творчества участников и гостей приветствовал начальник Академии ФСИН России, полковник внутренней службы Сергей Михайлович Никитюк, который отметил, что данное мероприятие является стартовой площадкой, где открываются молодые таланты и развиваются творческие и научные компетенции, выходящие за пределы образовательных программ. С приветственным словом к участникам Недели творчества обратился также председатель Рязанского регионального отделения Ассоциации юристов России Алексей Владимирович Тюменев. Ему как выпускнику академии было очень приятно и волнительно приветствовать юных талантов в стенах родного вуза.

В адрес участников и организаторов Недели творчества поступили приветственные адреса от Уполномоченного при Президенте Российской Федерации по правам ребенка, Губернатора Рязанской области, Федерального агентства по делам молодежи, Председателя Координационной службы Совета командующих Пограничными войсками государств - участников СНГ, Ассоциации юристов России. 


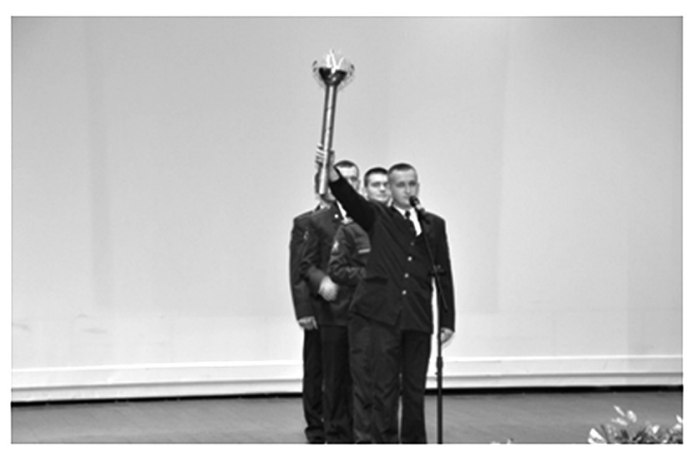

Зажжение символического огня

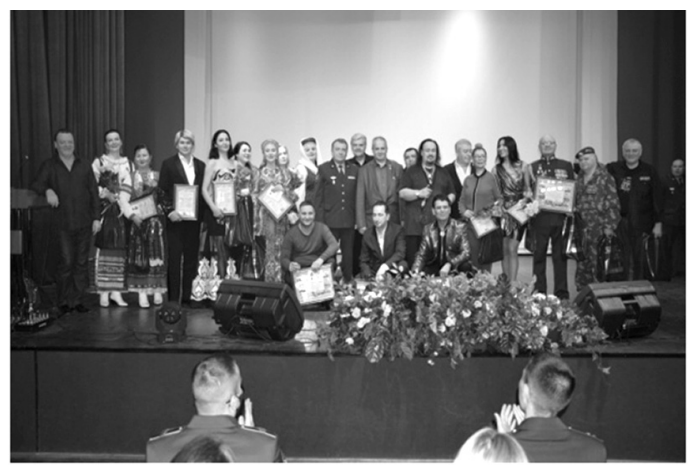

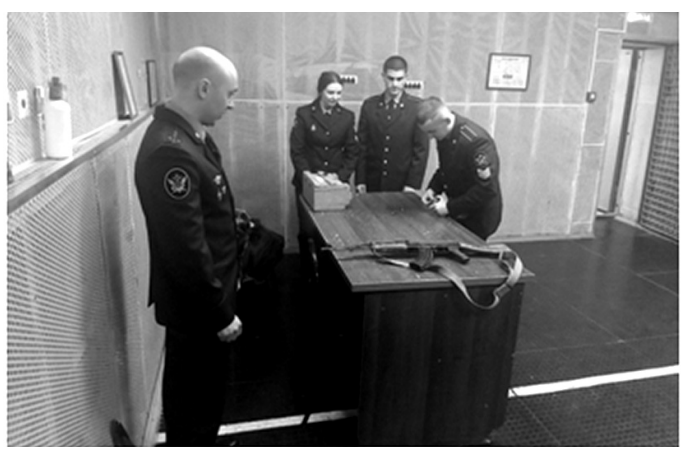

Сдача контрольных нормативов по огневой подготовке

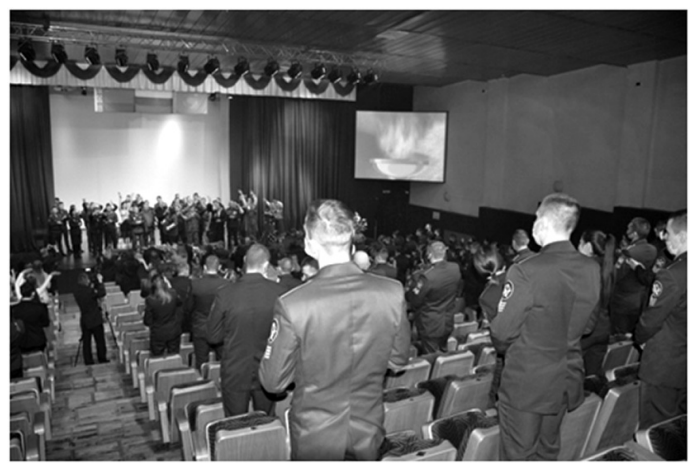

Концертная программа

Венцом церемонии открытия стало зажжение символического огня Недели творчества, которое было доверено капитанам команд-участников.

Настоящим украшением являлось двухчасовое выступление звезд российской эстрады, среди которых заслуженный артист России Александр Анатольевич Сaвин, звезда русского шансона Игорь Михайлович Герман и многие другие.

Помимо церемонии открытия в первый день Недели творчества стартовал конкурс на звание «Лучший курсант УИС». Конкурсанты представили свои портфолио, а также продемонстрировали навыки владения боевым оружием при сдаче контрольных нормативов по огневой подготовке.

Напряженным выдался второй день Недели творчества, в рамках которого было проведено сразу 19 мероприятий различной направленности. Неподдельный ин- терес у частников вызвали межвузовская интеллектуальная игра «Что? Где? Когда?», викторина «Знаток криминологии», круглый стол «Организация патриотической работы в вузах ФСИН России», дискуссионная сессия «Правомерность и эффективность применения физической силы, оружия и специальных средств сотрудниками УИС». Ожесточенная борьба разгорелась за шахматными досками среди мужской половины участников Недели творчества.

В программе третьего дня Недели творчества было запланировано проведение 16 мероприятий.

В рамках спортивного блока эмоционально насыщенными выдались соревнования по дартсу среди девушек. Кроме того, была определена лучшая группа спортивного совершенствования по служебно-прикладным видам спорта среди образовательных организаций ФСИН России. 


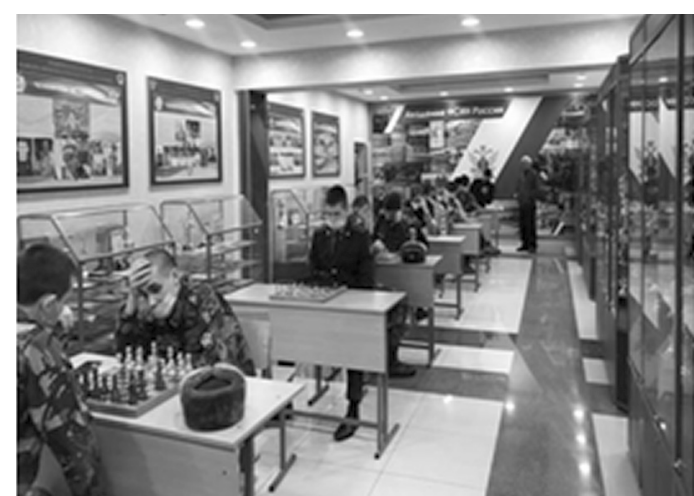

Соревнования по шахматам

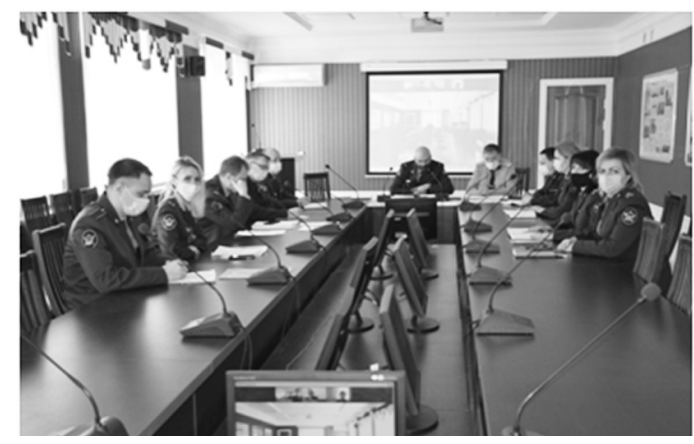

Жюри конкурса

Кроме того, были проведены викторина на знание основ традиционных религий России, научный поединок «Режимный день», конкурс рефератов «Уголовно-процессуальные аспекты деятельности УИС», межвузовская олимпиада по бухгалтерскому учету «Профессионал» и ряд других мероприятий.

Отдельной строкой в плане мероприятий третьего дня Недели творчества следует выделить конкурс проектов по актуальным проблемам обеспечения прав человека в сфере исполнения уголовных наказаний, который проходил под эгидой Уполномоченного по правам человека в Российской Федерации. Впервые данный конкурс прошел в 2018 году непосредственно под председательством Уполномоченного по правам человека в Российской Федерации Татьяны Николаевны Мос-

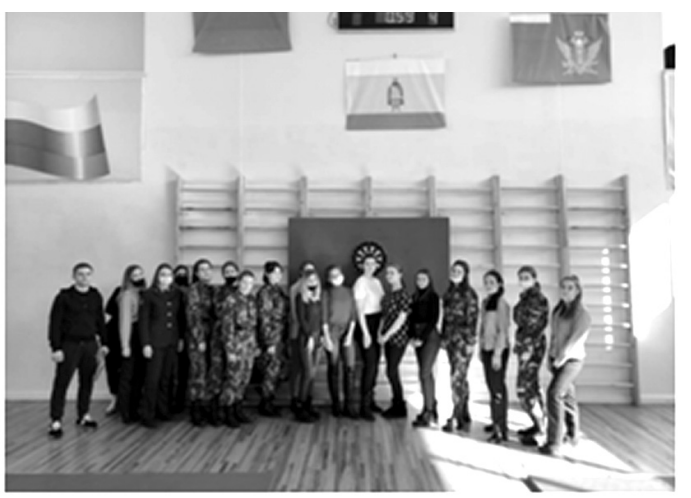

Участники соревнования по дартсу

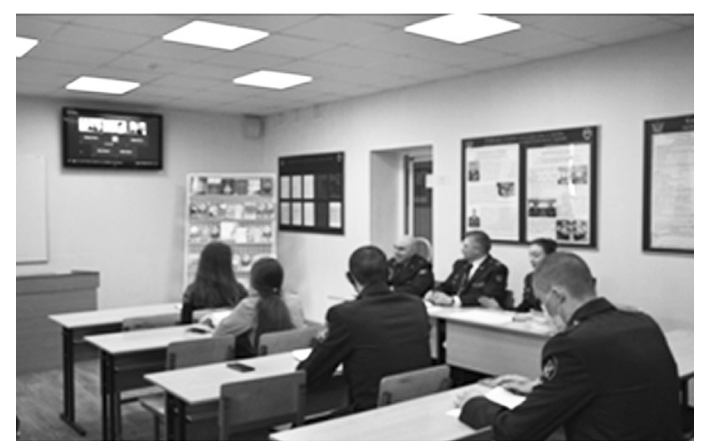

Участники и жюри конкурса

кальковой. В 2021 году он был проведен в онлайн-формате, председателем выступила начальник отдела аппарата Уполномоченного по правам человека в Российской Федерации Лариса Федоровна Пертли.

В этом году в качестве соорганизатора Недели творчества впервые выступил Аппарат Уполномоченного при Президенте Российской Федерации по правам ребенка. В связи с этим в рамках третьего дня Недели творчества под эгидой Уполномоченного при Президенте Российской Федерации по правам ребенка Анны Юрьевны Кузнецовой состоялся конкурс проектов по актуальным проблемам обеспечения прав ребенка «Дети имеют право». В качестве председателя жюри выступил советник Аппарата Уполномоченного при Президенте Российской Федерации по правам ребенка Михаил Михайлович Орлов. 


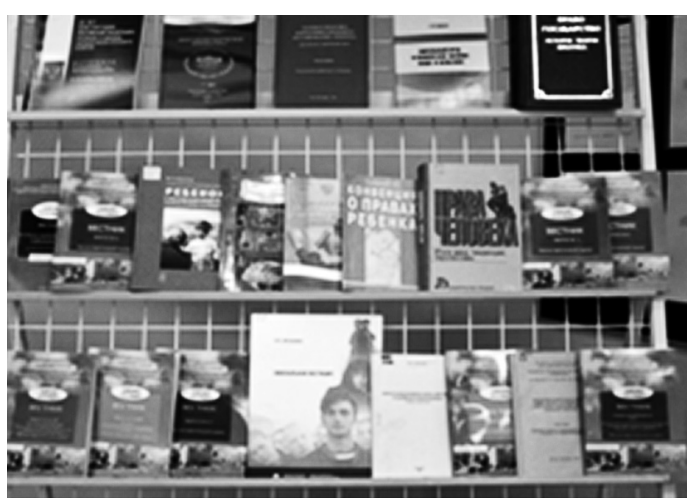

Выставка научных трудов, посвященная защите прав ребенка

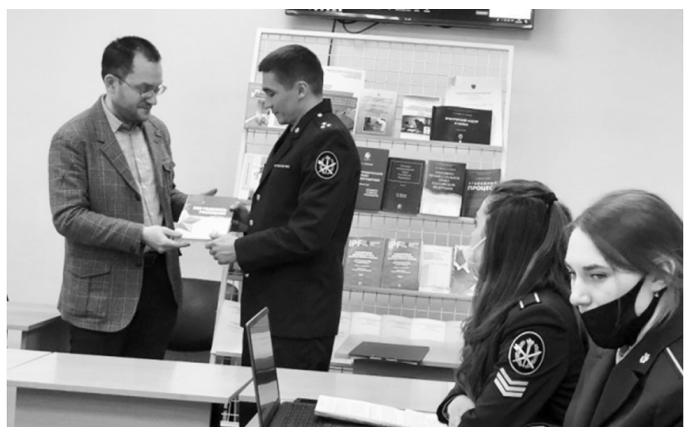

Конкурс «Моя малая Родина - земля Героя»

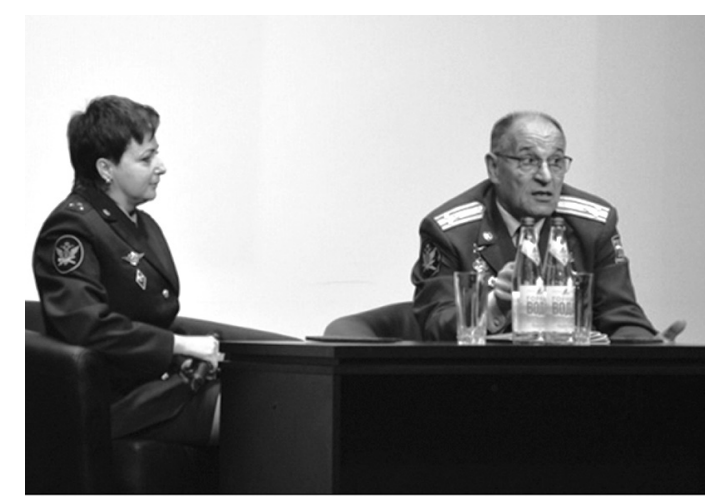

«Встреча с легендой» (П. П. Бодько )

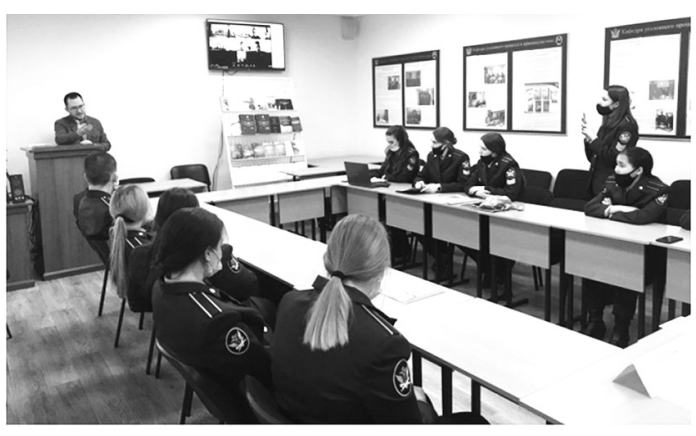

В рамках Недели творчества был также проведен ставший традиционным проект «Встреча с легендой», который направлен на развитие положительных профессиональных качеств и черт характера молодого поколения на примерах выдающихся людей и блестящих специалистов. В этом году участники Недели творчества встретились с легендой Академии ФСИН России, членом Президиума Совета Общероссийской общественной организации ветеранов уголовно-исполнительной системы Российской Федерации, председателем Комитета ветеранов академии Петром Петровичем Бодько. Он поделился яркими воспоминаниями о периодах учебы и службы, опытом преодоления возникающих трудностей, рассказал о своих многочисленных полезных увлечениях и ответил на вопросы ребят.
В предпоследний день Недели творчества состоялось 11 мероприятий научного, спортивного и творческого характера. Среди них особый интерес у участников вызвал конкурс мультимедийных презентаций «Моя малая Родина» и впервые проведенный в его рамках дополнительный конкурс в номинации «Моя малая Родина - земля Героя», приуроченный к 80-летию начала Великой Отечественной войны. Главной целью данного конкурса являлось формирование и развитие устойчивого патриотического мировоззрения, основанного на исторической памяти и уважении к подвигам наших предков, а также чувства нетерпимости к фальсификациям фактов истории Великой Отечественной войны.

Заключительный день Недели творчества также был насыщен разнообразными мероприятиями. 


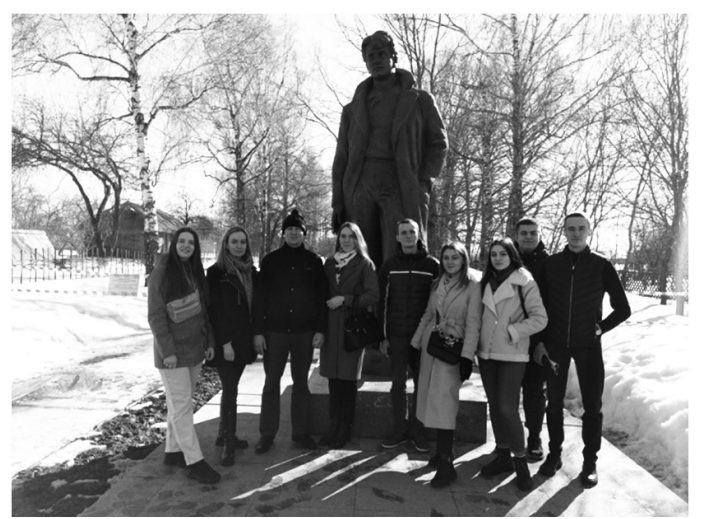

Участники Недели творчества в Государственном музее-заповеднике С. А. Есенина (село Константиново)

По традиции в этот день состоялась ежегодная Международная научно-теоретическая конференция адъюнктов, аспирантов, соискателей, курсантов и студентов «Человек: преступление и наказание». Это событие является одним из ключевых в научной жизни обучающихся академии, способствует повышению уровня профессиональной подготовки будущих специалистов УИС и посвящается обсуждению актуальных проблем совершенствования уголовного и уголовно-исполнительного законодательства, поиску эффективных форм и методов организации деятельности органов и учреждений УИС, рассмотрению правовых, криминологических, социально-экономических и психолого-педагогических аспектов исполнения и отбывания уголовных наказаний.

В рамках Конференции проходила работа пленарного заседания, а также 26 дискуссионных площадок, организованных кафедрами академии по различным научным направлениям.

В этот день также подводились итоги конкурса стенной печати, посвященного Дню работника уголовно-исполнительной системы Российской Федерации, и конкурса на звание «Лучший курсант УИС».

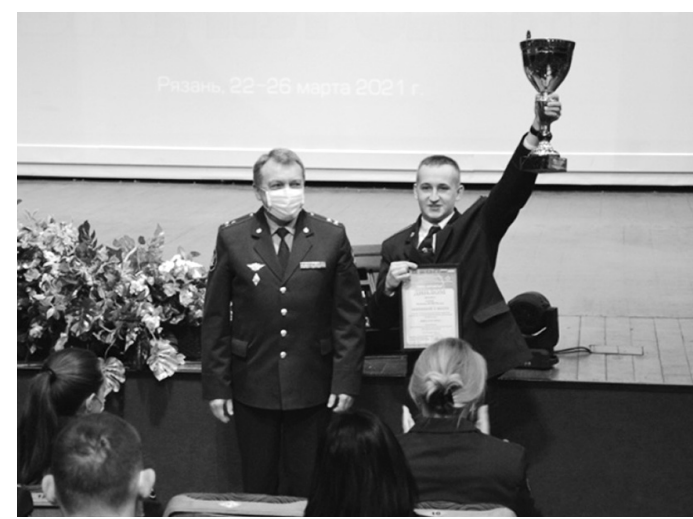

Награждение капитана команды академии кубком и дипломом

Однако не только проведением научных, спортивных и творческих мероприятий ограничились организаторы Недели творчества. По традиции для ее участников была разработана культурная программа, включающая в себя экскурсии с посещением Музея истории уголовно-исполнительной системы и Академии ФСИН России, Государственного музея-заповедника С. А. Есенина, Музея истории гвардейских воздушно-десантных войск, Музея военной автомобильной техники.

Кульминацией Недели творчества стала церемония торжественного закрытия с подведением итогов мероприятий и награждением победителей. В начале мероприятия участникам и организаторам Недели творчества было зачитано обращение директора ФСИН России Александра Петровича Калашникова, в котором он отметил, что интерес к проведению мероприятий подобного уровня возрастает год от года, а каждому участнику Недели творчества пожелал новых достижений и осуществления грандиозных планов.

За активное участие, глубину знаний, профессионализм, верность традициям и устоям УИС дипломами и грамотами были отмечены лучшие представители ко- 


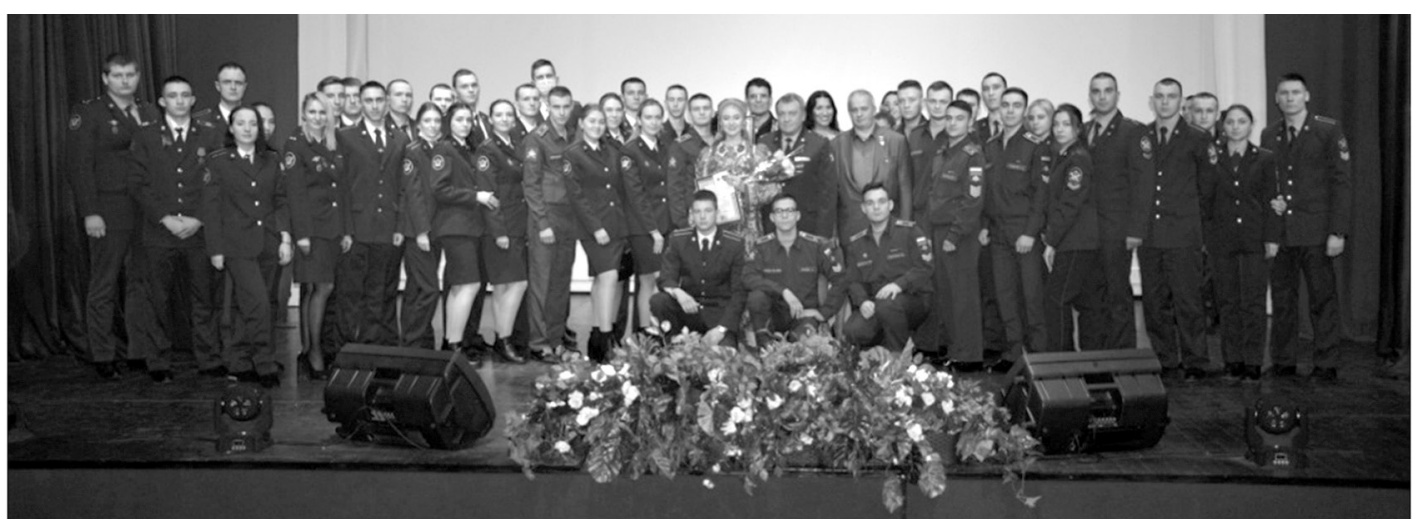

Участники Недели творчества

манд-участников от образовательных организаций ФСИН России.

С пожеланиями перед участниками Недели творчества выступили заместитель министра образования и молодежной политики Рязанской области Сергей Николаевич Хлыстов, заместитель министра физической культуры и спорта Рязанской области Юрий Юрьевич Колдин, которые также вручили почетные грамоты и благодарственные письма сотрудникам и курсантам академии от соответствующих министерств.

Выпускник академии, советник президента Молодежного Союза Экономистов и Финансистов Сергей Витальевич Лежнин вручил дипломы наиболее отличившимся курсантам академии за активную научную работу и успехи в учебе.

По итогам напряженной борьбы в рамках Недели творчества третье место в командном зачете завоевали команды Владимирского юридического института ФСИН России и Пермского института ФСИН России. Второе место в упорной борьбе разделили между собой команды Самарского юридического института ФСИН России и Военного университета Министерства обороны Российской Федерации. В очередной раз переходящий кубок «За I место» завоевала команда Акаде- мии ФСИН России. Победители и призеры были награждены кубками и дипломами, остальные команды-участники отмечены почетными грамотами.

Завершилась церемония закрытия погашением символического огня Недели творчества.

В своем заключительном слове начальник Академии ФСИН России полковник внутренней службы Сергей Михайлович Никитюк отметил, что за десять лет $\mathrm{He-}$ деля творчества стала широко известным мероприятием не только в России, но и за рубежом. Подобные мероприятия являются наиболее приемлемой практикой демонстрации своих достижений в науке, спорте и творчестве.

По окончании церемонии закрытия Недели творчества состоялся гала-концерт творческих коллективов команд-участников, создавших своими яркими выступлениями праздничную обстановку.

В целом Неделя творчества, насыщенная множеством событий научного, спортивного, творческого и культурного характера, прошла в дружеской и уютной атмосфере, надолго зарядив ее участников положительными эмоциями, вдохновением на новые идеи и свершения, а также радостью побед. Хочется верить, что за время Недели творчества они не только успели найти 
себе новых друзей, но и получили массу неповторимых впечатлений.

Без преувеличения можно сказать, что юбилейная Х Международная неделя творчества способствовала вовлечению молодых перспективных кадров уголовно-исполнительной системы Российской Федера- ции в углубленное изучение вопросов пенитенциарной науки, формированию новых исследовательских направлений и развитию научного сотрудничества, а также стимуляции личностного и профессионального роста как обучающихся, так и профессорско-преподавательского состава. $\diamond$ 
DOI 10.51522/2307-0382-2021-229-6-16-31

УДК $340.5+94(47)+1: 316$

\section{Н. Н. ТРОФИМОВА}

начальник научного центра ВЮИ ФСИН России, кандидат юридических наук, доцент, полковник внутренней службы

Владимир

\section{NATALIA N. TROFIMOVA}

Head of the Scientific Center of the VILE of the FPS of Russia, Candidate of Law, Associate Professor, Colonel of the Internal Service

Vladimir

\section{А. С. ТИМОщУК}

профессор кафедры гуманитарных и социально-экономических дисциплин ВЮИ ФСИН России, доктор философских наук, доцент, полковник внутренней службы Владимир

\section{ALEXEY S. TIMOSCHUK}

Professor of the Department of Humanities and Socio-Economic Disciplines of the VILE of the FPS of Russia, Doctor of Philosophy, Associate Professor, Colonel of the Internal Service Vladimir

\section{Хронодискретное моногеографическое сравнительное правоведение на примере уголовно-исполнительной системы Российской Федерации}

\section{Chrono-discrete monogeographic comparative jurisprudence on the example of the penal system of the Russian Federation}

Аннотация. В статье анализируются возможности методологии школы хронодискретного моногеографического сравнительного правоведения применительно к уголовно-исполнительной политике, которая рассматривается в контексте советского периода модерни-
Abstract. The article analyzes the possibilities of the methodology of the school of chrono-discrete monogeographic comparative jurisprudence in relation to the penal policy, which is considered in the context of the Soviet period of modernization of Russia. The subject of the article is the arrays 
зации России. Предметом статьи выступили массивы социально-правовой информации в области уголовного уложения, истории пенитенциарной системы, истории становления институтов общественного контроля, генезиса русского языка в политико-правовой сфере. Цель исследования - продемонстрировать, что пенитенциарная политика носит хронодискретный характер, что обусловлено особенностями цивилизационного отставания России в начале XX века и требованиями догоняющей модернизации ее технологического уклада. Методологическую основу исследования составил хронодискретный моногеографический сравнительно-правовой подход, который, помимо известных сравнительного, исторического, формально-правового видов анализа, исходит из следующих исследовательских установок и допущений: 1) объект берется в одной топологии, но в разных периодах; 2) ученый полагает, что имеет место хроноразрыв у социально-правовых и политических процессов. В результате проведенной работы изучены национальные особенности в эволюции пенитенциарной политики с конца XIX по конец XX века. Представлен ретроспективный анализ гуманизации уголовно-исполнительной политики и названы причины советской хронопаузы в соблюдении прав человека, обоснована историческая гетеродинамика УИС в системе государства и права. Косвенно затронуты проблемы взаимодействия пенитенциарной системы с институтами гражданского общества. Сделаны выводы о том, что актуальный гуманистический тренд развития УИС является естественным продолжением пенитенциарных реформ XIX века, произошедших после необходимой социотехнической модернизации России, выполненной партией большевиков.

Ключевые слова: уголовно-исполнительная система, наказание, временной разрыв, хронопауза, ХМСП, индустриализация, модернизация, нелинейная клиодинамика. of social and legal information in the field of the criminal law, the history of the penitentiary system, the history of the establishment of public control institutions, the genesis of the Russian language in the political and legal sphere. The purpose of the study is to demonstrate that the penitentiary policy is of a chrono-discrete nature, which is due to the peculiarities of Russia's civilizational backwardness at the early 20th century and the requirements of catching-up modernization of its technological structure. The methodological basis of the study was a chrono-discrete monogeographic comparative legal approach, which, in addition to the wellknown comparative, historical, formal legal types of analysis, proceeded from the following research attitudes and assumptions: 1) the object is taken in the same topology, but in different periods; 2) the scholar believes that there is a chronological gap in socio-legal and political processes. As a result of the work carried out, national characteristics in the evolution of penitentiary policy from the end of the 19 th to the end of the 20th centuries were studied. A retrospective analysis of the penal policy humanization is presented and the reasons for the Soviet chronopause in the observance of human rights are named, the historical heterodynamics of the penal system in the system of state and law is substantiated. Problems of interaction of the penitentiary system with civil society institutions are implicitly touched upon. It is concluded that the current humanistic trend in the development of the penal system is a natural continuation of the penitentiary reforms of the 19th century, continued after the necessary socio-technological modernization of Russia, carried out by the Bolshevik party.

Key words: penal system, punishment, time gap, chronopause, chrono-discrete monogeographic comparative legal approach (HMSP), industrialization, modernization, nonlinear cliodynamics.

12.00.08 Уголовное право и криминология; уголовно-исполнительное право (юридические науки) Criminal Law and Criminology; penal law (legal sciences)

12.00.01 Теория и история права и государства; история учений о праве и государстве (юридические науки) Theory and history of law and state; history of doctrines of law and state (legal sciences) 


\section{Введение}

Школа хронодискретного моногеографического сравнительного правоведения (ХМСП) зародилась в Нижнем Новгороде. Ее основатели, специалисты в сфеpe историко-правовой науки Демичев Алексей Андреевич и Демичев Кирилл Андреевич, задумали описать причины временных разрывов в развитии общественно-правовых систем. Научная школа провела десятки конференций, выработала научно-методологический аппарат и вполне может претендовать на успешную историко-правовую методологию анализа и прогноза развития российского общества. Основополагающая идея школы, которая заключается в том, что правовые явления имеют не только эволюционный, но и рекуррентный характер, весьма продуктивна и соответствует комплементарной логике неклассической науки, где объекты рассматриваются в своем историко-культурном контексте, эмерджентно и синергийно. Применение ХМСП-методологии доказало свою эффективность в отношении как гражданского права, так и уголовного, как материального, так и процессуального. Предметом ХМСП-анализа могут быть концепции и институты, принципы и кодексы. Цель исследования заключается в том, чтобы ответить на вопрос, почему явление имело место в истории, затем прервалось и возобновилось снова.

А. А. Демичев отмечает, что концептуальный каркас школы включает следующие категории: «ХМСП-методология», «сравнительное правоведение», «хронодискретная идея», «хронодискретное явление», «хронодискретный институт», «хроноразрыв», «хронопауза», при этом научное направление не ограничивается темпоральными и географическими рамками российского общества [1].
ХМСП интерпретирует советское общество как модернизационный проект, который был призван в ускоренном режиме сократить отставание от передовых капиталистических стран по экономическим, индустриальным и социокультурным параметрам. Форсированный характер модернизации не мог не испытать на прочность социальные связи, он также определил драматическую судьбу российской оппозиции.

ХМСП-методология актуализирует интерес к динамике исторического процесса России, который представляет собой диалектику преемственности и хроноразрывов и где советское прошлое рассматривается объективированно, без идеологических штампов. Экстремальное ускорение социально-экономических процессов и длительное прерывание деятельности нормальных гуманистических форм защиты прав личности и реализации индивидуальных свобод создавали негативный образ СССР, подрывали его ресурс «мягкой силы». Вместе с тем, как уже ранее это описал А. С. Тимощук, асимметрии и хроноразрывы, аномалии и антиномии государства были ответом на неравновесность самого развития [2].

Флуктуационные тенденции к возврату на нормальный курс развития были задолго до М. С. Горбачева, официально начавшего дискурс комфортного социализма с человеческим лицом. Самым первым могильщиком единственного возможного коммунизма как военной диктатуры стал Н. С. Хрущев, допустивший индивидуальное вместо коммунального, потребление вместо самоотдачи. Как объясняет А. А. Ивин, от этого размягчения социализма до перестройки оставалось уже рукой подать [3]. Кривая хроноразрыва устремилась к точке восстановления дореволюционных институтов и форм 
реализации прав человека. Процессуальные институты, апелляционное производство, свобода вероисповедания, частная собственность, суд присяжных, нотариат, общественные наблюдательные советы, ипотечное законодательство, духовное окормление заключенных, военное духовенство - восстановление этих социальных форм является шагами к человекомерному обществу.

\section{Пенитенциарная квалиметрия жизни}

Уголовно-исполнительная система в новой России занимает особое место как один из наиболее ярких индикаторов состояния развития общества и государства. Известное, приписываемое Ф. М. Достоевскому высказывание «Если общество хочет проверить уровень своей цивилизации, пусть заглянет в тюрьму» как нельзя точно отражает идею того, что квалиметрия человечности начинается не с супермаркета и не с индустрии пластической хирургии, а с инспекции тех мест, где homo sapiens находится в наиболее отчужденных лиминальных состояниях, - тюрьма, детский дом, дом престарелых. По сравнению с другими домами призрения тюрьма - это самый массовый институт, через который проходят сотни тысяч судеб. Она формирует и транслирует свою субкультуру, язык, нравы.

Коренные изменения после революционных событий октября 1917 года инициировали череду масштабных разрывов в общественных отношениях, институтах, праве. Время, именуемое в культурологии Серебряным веком, стало «золотым» для развития общественного сознания. За короткий период между реформами Александра II и революцией 1917 года были достигнуты очень важные сдвиги в общественном развитии, политической системе, уголовном законодательстве. Однако они были уже запоздалыми ответами на вызовы времени. Изучение правовых хроноразрывов в России имеет поэтому драматический оттенок «упущенных возможностей» - комментирует Н. Н. Трофимова [4].

Начало гуманизации уголовно-исполнительной системы было положено в конце XIX века стараниями государственных и общественных деятелей, таких как министры юстиции Н. В. Муравьев и К. И. Пален, заместитель министра внутренних дел А. Б. Лобанов-Ростовский, тюрьмоведы В. А. Соллогуб и М. Н. Галкин-Враской, член Государственного совета К. К. Грот.

Улучшение питания и проживания арестантов, оплачиваемый труд, организация артелей с обучением ремеслу - эксперименты, начатые в Московской, Царицынской и Самарской губерниях, впоследствии должны были быть распространены по всей Российской империи, но революционные события отсрочили их на 70 лет.

Цель реформ конца XIX века - это модернизация пенитенциарных учреждений в соответствии с социально-экономическими и политическими условиями развития российского общества и государства и с учетом европейских достижений и стандартов в уголовно-исполнительной сфере Н. Н. Трофимова сообщает, что реализация данной цели предполагала улучшение качественного состояния мест заключения и условий содержания в них [5].

Как и в прошлом, современные реформы вызывают недоумение в массе соотечественников: «такие условия не у всех граждан России есть». Ведь реформы XIX века начали создавать бытовые удобства для заключенных в виде водопровода, парового отопления, канализации, вентиляции, электрического освещения, которыми не 
обладала масса беднейшего населения дореволюционной России. Социально-бытовое неравенство было прервано хронопаузой советского распределительного эгалитаризма. Всеобщий достаток достигался в том числе ликвидацией различий в социально-бытовом развитии. Сегодня мы можем говорить не только о хронодискретности институтов гражданского общества, но и о возврате социального неравенства.

Существенной хронодискретной вехой является Уголовное уложение 1903 года, где реализовывались вопросы защиты частной собственности, упрощение системы наказаний, смягчение наказаний несовершеннолетних, закрепление принципа законности. Сотрудник ВШЭ Ф. Ф. Дудырев указывает, что последний уголовно-правовой акт Российской империи исправлял анахронизмы прошлого - слишком большое внимание на наказании, устарелость русского материального права, сословные привилегии [6]. Однако советское уголовное право возвратило классовый подход, репрессивность и применение кодекса в политической борьбе.

По мнению Н. Н. Трофимовой и К. М. Щепетова, международный обмен пенологическим опытом, тюремный патронат, постпенитенциарное попечение - все это уже было у нас на этапе нормального эволюционного развития системы [7]. Приход большевиков к власти в 1917 году - это граница между обществом поступательной эволюции и обществом революционного скачка. Разрыв карательной политики был неизбежен, поскольку достижение высоких показателей не было обусловлено самим ходом истории. Социальные изменения нужно было форсировать, а это означало неизбежность террора.

Возвращение российского государства к либеральной модели общественной жизни и наказания стало возможно только после ускоренной индустриализации, перераспределения собственности, выравнивания уровня жизни. Умеренный экономический либерализм, дополняемый нравственным консерватизмом, есть естественное развитие общества процветания, к которому приходят после ликвидации разрыва в имущественном состоянии. Запретить лозунг «Грабь награбленное!» можно только в условиях появления массового класса собственников. Советская власть, отрицавшая частную собственность, подготовила этот класс благодаря социально-экономическому рывку в производстве потребительских товаров, типовом жилищном строительстве, индустриализации и урбанизации.

Открытие постсоветской эпохи заключалось в том, что путь развития до октября 1917 года - это нормальная эволюционная парадигма, прервав которую, мы не можем предложить ничего лучшего, как встать снова на путь государственно-правовых институтов начала XX века. Частная собственность, парламент, прокуратура, адвокатура, мировой суд, суд присяжных, институты гражданского общества - все это незаменимые инструменты открытого общества, полагают Н. Н. Трофимова и Д. И. Рубцов [8]. Сотрудник рязанской Академии ФСИН России А. В. Илюхин делает прогноз, что некоторые пенитенциарные институты Российской империи вполне могут получить второе рождение в современной России, в частности это ссылка, способная разгрузить большие города и поддержать удаленные территории трудовыми ресурсами [9].

Юридически в советский период не было разрыва между гуманистической и репрессивной системами наказания, была только хронопауза 1918-1936 годов, когда и на уровне законов действовал классовый принцип наказания. Формально юридиче- 
ски он устраняется уже в сталинской конституции, предусматривавшей демократические права (Конституция 1936 года, глава X: всеобщие права граждан СССР на труд, отдых, материальное обеспечение в старости, образование и другие). В этом заключается существенное отличие между двумя тоталитарными режимами. В нацистской Германии был хроноразрыв между юриспруденцией гуманистической и репрессивной нацистской, когда на уровне закона были сформированы концепции «недочеловека» и «окончательного решения еврейского вопроса». О хронопаузе в большевистской России следует говорить, когда воинствующая риторика по отношению к «бывшим» постепенно на уровне законов угасла.

Конечно, это не означает, что на социально-экономическом уровне в СССР произошло восстановление в правах либеральных институтов. Здесь как раз наблюдается хроноразрыв, в отличие от Западной Германии, где в постнацистский период социально-экономической политики Аденауэра были восстановлены институты гражданского общества, была запущена программа реституции собственности евреев Wiedergutmachung.

Социально-экономический хроноразрыв института собственности оказался ощутимым, и возврат института собственности в 90-е годы происходил болезненно и травматично, а программа реституции была осуществлена только выборочно. Несмотря на 30-летнее восстановление института собственности, периодически слышны заявления о необходимости реприватизации, пересмотра результатов ваучеризации. Советская мораль, делавшая честность и справедливость несовместимыми с владением богатством, до сих пор имеет значительное количество сторонников в условиях нового социального расслоения. В этом контексте становится очевидной причина нарушения нормального развития права и государства - ему предшествует социально-экономический и классовый разрыв. ХМСП-методология в этом смысле имеет гуманистическую бесконфликтную направленность, в отличие от марксизма. Она допускает устойчивое поступательное развитие общественных и государственных институтов в такой политической системе, где имеет место снятие имущественных, образовательных, культурных антиномий. И напротив, растущее экономическое расслоение, люмпенизация, маргинализация - все это факторы увеличения преступлений не только против собственности, но и против государства, которое в ответ, стремясь защитить интересы верхов, становится все более репрессивным.

События 1917 года в нашей стране также получают переосмысление в свете ХМСП-методологии. Революция - это не только насильственная перестройка повседневности, это еще ускоренная социальная модернизация или быстрый насильственный способ передела собственности. Подобно тому, как повстанцы Пугачева жгли деловые бумаги, что символизировало свободу от права собственности на крепостную зависимость, Октябрьская революция означала конфискацию и национализацию [10]. Машина насилия не может остановиться только на классовых врагах. На следующем этапе врагами становятся вчерашние союзники: левые эсеры и анархисты. После этого врагов начинают искать среди своих партийцев и беспартийных. ГУЛАГ уже был встроен в саму логику ускоренного социального преобразования, и он стал символом сталинской модернизации. Как же менялась пенитенциарная политика с точки зрения ХМСП-методологии? 


\section{Истоки ГУЛАГа}

Уголовно-исполнительная система оказывает значительное влияние на все сферы общества, а в особенности на институциональную, правовую, медицинскую, международную. Тюрьма социализирует значительный класс людей во все времена, зачастую именно там создается образ будущего мира. В свое время она была университетом большевиков, а когда они пришли к власти, снова стала символом политического вольнодумства, диссидентского движения.

Сегодня, когда столько внимания уделяется недопущению нарушения прав подследственных, подсудимых и отбывающих наказание, принципиально важно разобраться, почему прервалась гуманизация пенитенциарной политики, начало которой было положено в конце XIX века. Наиболее существенные причины гуманистического хроноразрыва в уголовно-исполнительной политике крылись в социальных противоречиях того времени.

Советская власть действительно не питала никаких симпатий к представителям непролетарского происхождения. Буржуазия, духовенство, помещики, дворяне, зажиточные крестьяне были поражены в правах и испытали на себе гонения, высылки, расстрелы. Лишенцы не имели избирательных прав, не могли устроиться на работу, кредитоваться, получить карточки; они облагались дополнительными налогами, а их дети не могли получить среднее и высшее образование. По мере расширения программы раскулачивания у крестьян не только забирали дом, имущество и продовольствие, с 1932 года они депортировались на лесо- и торфозаготовки. Среди спецпереселенцев, направлявшихся преимущественно на Урал, в Сибирь и Северный Казахстан, была высокая смертность от холода, голода и болезней. Трудпоселки нередко представляли собой необжитую территорию, куда ссылались «неблагонадежные» элементы.

Нормативная база раскулачивания была обусловлена политикой социалистического наступления на капиталистические элементы деревни, сформулированной как обязательное членство в кооперативном плане В. И. Ленина. Реализация И. В. Сталиным кооперирования деревни как общеобязательного участия всех крестьян была дополнена изменением добровольности взносов на принудительное обобществление.

Кооперативное законодательство эволюционирует от разнообразия экономических регуляторов кооперации, включая аренду земли и использование наемного труда, до представления кооперации как классового инструмента государственной политики с практикой запрета выезда из колхоза, отказа в выдаче паспорта, лишения избирательного права, конфискации имущества, выселения на неосвоенные территории и вплоть до самого революционного метода - ликвидации «эксплуататоров крестьянства». Существенными детерминантами политики в отношении деревни становятся война, нужды Красной армии и пролетариата в городах, заставляющие СНК РСФСР выпускать акты об изъятии сельскохозяйственных продуктов у крестьян. Эту динамику можно проследить в ранних правовых актах до НЭПа (19181921 годы), во время НЭПа (1921-1929 годы) и после НЭПа: декрет ВЦИК «О социализации земли» от 19.02.1918; декрет СНК РСФСР «О разверстке между производящими губерниями зерновых хлебов и фуража, подлежащих отчуждению в распоряжение государства» от 11.01.1919; декрет ВЦИК «О замене продовольственной и сырьевой разверстки натуральным налогом» от 21.03.1921; декрет ВЦИК и 
СНК РСФСР «О сельскохозяйственной кооперации» от 16.08.1921; Земельный кодекс 1922 года; постановление ВКП(б) «О темпе коллективизации и мерах помощи государственному колхозному строительству» от 05.01.1930; Примерный устав сельскохозяйственной артели 1930 года; постановление ЦИК и СНК СССР «О мероприятиях по укреплению социалистического переустройства сельского хозяйства в районах сплошной коллективизации и по борьбе с кулачеством» от 01.02.1930; постановление ЦИК и СНК СССР «О недопущении кулаков и лишенцев в кооперацию» от 13.11.1930; постановление ЦИК и СНК СССР «О порядке отходничества из колхозов» от 17.03.1933; постановление СНК СССР «О прописке паспортов колхозников-отходников, поступающих на работу в предприятия без договоров с хозорганами» от 19.09.1934 - узнаем мы из работ Е. А. Пановой [11] и Е. В. Королевой [12].

Беспрецедентная кампания по искоренению «классово-чуждых элементов» дополнилась шпиономанией, борьбой с контрреволюцией и просто террором как практикой устрашения общества. Поддерживалась атмосфера взаимного недоверия: детей врагов народа не брали в школы, а их родственников - на работу.

Ужесточение условий содержания заключенных происходило по многим причинам, среди них и второстепенные, которые сопровождали борьбу с классовыми врагами. Известно, что региональные партийные руководители, желая отличиться перед высшим руководством, просили увеличить пришедшие из Кремля планы по ликвидации неблагонадежных. И. В. Сталину приходилось порой останавливать наиболее рьяных сторонников репрессий. Поэтому сегодня объяснять феномен ГУЛАГа культом вождя было бы упрощением реальности. Масса руководи- телей на местах была готова к террору, и в этом смысле прерывание гуманистической традиции - это массовый панпсихический феномен, актуализация воли толпы, жаждущей крови.

Мы можем увидеть сходное помешательство насилием во Французской революции, когда одержимые террором Робеспьер, Марат, Кутон, Сен-Жюст осознают себя проводниками счастливого будущего нации, для которого нужны горы трупов, и считают, что ради торжества идей народовластия, демократии, прав и свобод нации, истины и справедливости необходимо уничтожить всех без исключения врагов родины.

Третий интернационал и борьба за мировое господство пролетариата есть, как известно, продолжение революционного радикализма Парижской коммуны. Вечное братство эгалитарной справедливости оказалось утопическим проектом, целостность которого необходимо было поддерживать, зачищая политический конвент от оппозиции.

Красная Россия ориентировалась на Парижскую коммуну и сама затем стала образцом для других диктатур - Китая и Вьетнама, Северной Кореи и Камбоджи, где были уничтожены миллионы граждан. Ким Ир Сен, Мао Цзэдун, Пол Пот вдохновлялись примером Маркса, Ленина и Сталина. Прерывание гуманистической традиции во всех этих государствах связано с дестабилизацией социальных отношений.

Представлять Сталина кровожадным монстром было бы ошибочным. Сама партийная и общественная среда давала одобрение на жесткий курс. Лозунг № 1 того времени - «Смерть изменникам Родины». Обратим внимание на рупор партии - массмедиа, которые со страниц газет призывали «клеймить наймитов», «жечь подлых 
шпионов и убийц», «разоблачить всех двурушников», «крепче ударить», «идти в наступление на разгильдяйство», «ударить социалистическим штурмом по оппортунизму», «призвать к суровому суду правых отщепенцев - предателей и изменников родины». Каждодневный труд воспринимался как передовая, фронт, борьба. «Нужно драться за урожай, идти в атаку на засуху, мобилизовать комсомольцев, встретить новый учебный год во всеоружии» - фиксируют в своем исследовании исторические изменения русского языка О. А. Мусорина и С. Г. Сорокина [13].

Трудно ожидать образцов гуманного поведения от обездоленной бедноты. Пролетариат и безземельное крестьянство ратовали за насилие, так как оно представлялось наиболее естественным в рамках классовой борьбы. Раскулачивание порой превращалось в дележ имущества тех, кто мог позволить себе купить городскую обувь и железные кровати.

Говоря о причинах хроноразрыва карательной политики в истории России, мы не должны забывать, что существенная причина, как бы это ни было очевидно, заключалась в том, что советский режим постоянно испытывал на себе давление не только извне, но и изнутри. Им были недовольны не только «антисоветские элементы», то есть белогвардейцы, консервативное духовенство, представители оппозиционных партий. Постепенно сформировались внутрипартийные группы, которые боролись за «дело Ильича». Демократические процессы действовали неумолимо. Открытый парламентаризм, яркая характеристика политической истории России начала XX века, которым воспользовалась партия большевиков и который она так презирала, преследуя несогласных, вернулся вновь в виде внутренней борьбы за лидерство идей. Троцкизм, о котором мы сейчас уже стали забывать, означал яростную конкуренцию элит внутри партии большевиков. Лев Троцкий был самым сильным оппозиционером, имея революционные заслуги и авторитет в армии. Помимо него несогласными были как старые кадры, имевшие особенное мнение (Г. Е Зиновьев, Л. Б. Каменев, Н. И. Бухарин, А. И. Рыков, М. П. Томский, А. С. Енукидзе), так и новые (Г. Г. Ягода, М. Н. Тухачевский).

Бескомпромиссность большевиков в создании советской (то есть демократической, представительской!) власти диалектически дополняется разгоном Учредительного собрания, преследованием инакомыслящих. Леворадикальный марксизм не мог быть иным. Большевизм означал дисциплинированный авангард, использующий методы жесткой диктатуры, государственного террора, экспроприации имущества. Его историческим архетипом, как мы уже говорили, можно считать Парижскую коммуну.

Лаг в поступательном эволюционном развитии России возник вследствие военно-политического и экономического отставания, и большевизм решительно предлагал его преодолеть. Сталинизм - это последовательная часть большевизма, методическая работа по организации диктатуры партийной элиты. Номенклатурное воплощение рабочего правительства было более реалистическим проектом, нежели коммунитарный идеал Французской революции.

Хроноразрыв в карательной политике наступил не из-за личности Сталина. Террор - это общее место для революционеров, это ответ на вопрос, как достичь идеалов равенства, братства, свободы при наличии несогласных. Риторика борьбы с врагами народа была неизбежна после нарушения нормальной поступательной эволюции государства и общества. 
Если и обвинять Сталина в репрессиях, то под этим надо подразумевать, что он являлся лучшим бюрократом из всех большевиков, методически и системно наладившим дело террора. При всем жандармском характере царской России такой масштаб репрессий там даже не снился. Тюремная политика с конца XIX века шла уверенно по пути гуманистических реформ. В чем же экономическая причина прерывания этой тенденции?

Отправная точка образования ГУЛАГа это наложение классовой борьбы на потребность в подневольном труде, дешевом источнике индустриалиазации, когда решение сверхзадач молодого технологического государства достигалось доиндустриальными методами. Субъекты красного терроpa - заключенные ГУЛАГа были брошены на стройки века, на освоение удаленных от центра, но богатых природно-сырьевыми ресурсами территорий СССР, об этом повествуют в своих исследованиях Н. Ю. Белых, Л. И. Бородкин, С. Эртц, П. Грегори, О. В. Хлевнюк $[14,15,16]$.

Заведующий кафедрой истории и культуры Ухтинского государственного технического университета А. Н. Кустышев так объясняет сущность государственной лагерной политики: «Анализ имеющихся по теме исследования источников показывает, что в предвоенный период в ведении НКВД находились крупные строительные объекты, запуск которых имел важное значение для экономики страны. Наличие огромных людских ресурсов, находившихся в распоряжении Наркомата внутренних дел, породило иллюзию быстрого решения задач, связанных с экономическим развитием страны, способствовало принятию планов форсированного возведения крупнейших производственных объектов» [17].

Лагерная система заменила царскую тюрьму, так как соответствовала задачам промышленного рывка, масштабному плану открытия сотен предприятий металлургического, химического, лесообрабатывающего профиля.

Данная статья не ставит перед собой цель изучить механизмы принуждения, способы управления и правовые акты исправительно-трудовых лагерей, этапы становления ГУЛАГа. Исследование нацелено на изучение пенитенциарной социодинамики с учетом ХМСП-процессов. Юридические основы труда заключенных, управление лагерями, экономические функции ГУЛАГа, деятельность самих исправительных учреждений исследованы в работах Н. А. Беловой, Л. И. Бородкина, Г. М. Ивановой, В. А. Козлова, О. В. Хлевнюка, И. П. Упорова и других. Огромный пласт исторической информации в отношении иных «неблагонадежных» категорий населения, видов наказаний и оснований их назначений, статистических данных и нормирования использования труда осужденных содержится в исследованиях С. И. Кузьмина [18].

Несомненно, гуманизм не означает попустительства, а репрессии нельзя представлять как невроз Сталина. Авторы стремились продемонстрировать, как логика революционного террора соответствовала социальной инженерии молодого государства и уровню развития правосознания населения. В деле удушения контрреволюции не могло быть сомнений и отступлений, а под категорию антисоветских граждан, действительно, попадали очень многие из разнородной массы народов и социальных групп.

В статье также не обсуждается деятельность правозащитных некоммерческих организаций, таких как Международное историко-просветительское, благотворительное и правозащитное общество «Мемориал», фонд «В защиту прав заключенных», 
Московская Хельсинская Группа и другие организации, ведущих исследовательские программы, посвященные жертвам политического террора. Деятельность правозащитников освещена в трудах Л. М. Алексеевой, А. В. Гавриловой, В. Н. Казьмина, М. В. Шавруковой. Институты гражданского общества, процессы реабилитации узников ГУЛАГа - это часть становления нормального общества, приходящего на смену форсированному социализму.

Репрессии в условиях разрухи стали инструментом мобилизационного хозяйствования. Миллионы трудоспособных осуществляли грандиозный план индустриализации, будучи занятыми на тяжелых работах - земляных, дорожных, лесозаготовительных, рудодобывающих и подобных. Ручной труд миллионов заключенных и спецпереселенцев в условиях слабой технической вооруженности - это одна из основ индустриального рывка. Стройки века велись главным образом с использованием самых простых инструментов - пил, топоров, лопат, кирк, тачек.

Трудовые колонии осуществляли капитальное строительство. ГУЛАГ - это огромный экономический комплекс: лесное управление, горно-металлургическая, топливная и дорожно-транспортная система. Актюбинский комбинат, Белбалткомбинат, Бирлаг, Владивостоклаг, Волгострой, Воркутпечлаг, Вятлаг, Джезказганский комбинат, Дальстрой, Ивдельлаг, Каргопольлаг, Карлаг, Краслаг, Куйбышевстрой, Кулойлаг, Локчимлаг, Новотамбовлаг, Онеголаг, Провлаг, Райчихлаг, Североникель, Севурлаг, Свирлаг, Соликамстрой, Темлаг, Томасинлаг, Унжлаг, Усольлаг, Устьвымлаг, Ухтижемлаг, Южпечстрой все это свидетельства трудового подвига заключенных, которые добывали для страны лес и уголь, золото и олово, медь и никель, цемент и целлюлозу, электроэнергию, строили дорожные сети, заготавливали рыбу и овощи. Капитальное строительство, гидротехнические сооружения, аэродромы, радиостанции, шоссейные линии, судостроение - вклад осужденных в экономику СССР поистине огромен. НКВД представляло собой большой хозяйствующий субъект с крупными промышленными мощностями.

Механизм ГУЛАГа использовался для ускоренной модернизации производства. Не справляешься с заданиями партии в лагеря на трудовое перевоспитание. Эта причина, на наш взгляд, является одной из центральных. Возможно, она даже перевешивает идеологические разногласия. Ведь, несмотря на свои репрессивные практики, партия большевиков исходила из демократических принципов и защиты прав человека. Исправительно-трудовой кодекс 1924 года, сталинская конституция 1936 года, советская прокуратура - это примеры общенародных демократических текстов и институтов, которые не всегда находили воплощение в реальности. Первая половина XX века, в принципе, вошла в историю как эпоха жестокого обращения с массами людей (лагеря, депортации, геноцид).

Память о репрессиях постепенно покрывается все новыми и новыми слоями медиатизации. Музей истории ГУЛАГа в Москве - это только один «часовой» памяти страшного прошлого нашей страны, и его не хватает для меморизации травмы прошлого, которая постепенно вытесняется из общественного сознания.

\section{Выводы}

Представления о поступательном развитии общества и его институтов следует дополнить нелинейными факторами временного разрыва или хронопаузы, когда общество догоняющего типа реализует 
угнетенные доселе тренды. Нормальное классическое развитие России было прервано из-за социально-экономического отставания, когда нужно было перестраивать общественные отношения, осуществлять индустриализацию, урбанизацию, механизацию сельского хозяйства. Огромная аграрная страна не могла принять европейские стандарты содержания заключенных в условиях обострения социальных противоречий. Большевики - это партия мобилизационного рывка, ускоренного социально-экономического развития, на алтарь которого были принесены миллионные жертвы ГУЛАГа.

При этом хроноразрыв в России реализовался по неклассическому сценарию, когда некоторое подобие демократизма и гуманизма по отношению к осужденным можно было усмотреть в выступлениях и действиях первых лиц государства в самые первые годы советской власти, а также после хрущевской оттепели.

Если говорить о декларативной части советской юстиции, то она имела гуманистический фасад на протяжении всего периода своего существования. В советской прессе регулярно публиковали статьи о социальной защите семей заключенных, об улучшении их быта, об освобождении женщин и детей от трудовой повинности, о чем сообщают М. М. Горбунова, Д. И. Рубцов и Н. Н. Трофимова [19].

Исправительно-трудовой кодекс РСФСР 1924 года также можно рассматривать как гуманитарную завесу над репрессивной системой. В тексте идет отсылка к прогрессивной системе социальной защиты, комиссионному рассмотрению надзора за осужденными, участию народных судей и представителей профсоюза в наблюдательной комиссии, к значительному применению принудительных работ без лишения свободы, к учету склонности заключенно- го к тому или иному виду труда, к защите прав беременных заключенных женщин, к организации постпенитенциарных институтов, оказанию юридической и медицинской помощи, профессиональному и общеобразовательному развитию заключенных.

Уголовно-исполнительная система является неклассическим хронодискретным институтом, ее гуманистические стандарты были сформированы в конце XIX - начале XX века, специфическим образом трансформировались в репрессивно-исправительную советскую систему и возродились только в конце XX века, когда был воссоздан и сам гуманистический контекст новой России, а именно гражданское общество.

Хроноразрыв в развитии уголовно-исполнительной системы 1917-1989 годов вызван реализацией догоняющего плана модернизации государства, вызвавшей обострение классовых противоречий и необходимость имплементации мобилизационной экономики, одним из условий которой стал принудительный труд заключенных.

Хронодискретная пауза в развитии уголовной политики имеет, таким образом, не просто формально-юридический характер, когда в 1924 году принимается Исправительно-трудовой кодекс. Фактическая пауза наступила вследствие классовой концепции общества.

ХМСП-анализ позволяет прийти к системным выводам о необходимости профилактики гуманитарных разрывов в пенитенциарной политике, что невозможно без снятия социальных конфликтов труда и капитала. Безработица, коррупция, разрыв между бедными и богатыми это социальная почва для дестабилизации устойчивого развития государства. И здесь поправки в Конституцию о со- 
циальных гарантиях - это только первый шаг. Чтобы Россия устойчиво развивалась без разрывов и социальных потрясений, необходимо комплексное, систематическое и последовательное выравнивание социально-экономического уровня жизни населения, развитие среднего класса.

При раскрытии социально-экономических проблем постсоветской России авторами статьи были рассмотрены не все феномены. Своих исследователей в ХМСП-методологии ждут такие явления, как рэкет, новые русские, демонстративное потребление, меценатство, рекомендательная контора (сейчас это называется «специализированное агентство по подбору персонала»). Например, до революции в барских домах было много видов занятости (управляющий имением, экономка, лакей, гувернантка, кормилица, танцмейстер, кухарка, половой, садовник, конюх, егерь, каретник, кучер, прачка), но после раскрепощения прислуги они были упразднены. Революция трансформировала рынок труда, и эти профессии практически исчезли; только советская номенклатура могла себе позволить стыдливо нанимать прислугу. В новом буржуазном российском обществе стыдиться прислуги не принято и многие из этих занятостей возвращаются. Пока только армия сопротивляется и не приемлет денщиков и адъютантов. Домработница, няня, батлер, охранник, горничная - востребованные кадры в имениях олигархов. В связи с появлением новой буржуазии и дифференциацией стилей потребления спрос на домоводство очень высок. Рынок российской прислуги насчитывает несколько миллионов самозанятых.

Продолжая идею хронодискретности и учитывая, что многие процессы в истории развиваются по спирали, не хотелось бы думать, что отдельные явления ждут своего нового часа (профсоюз, революция, комиссар, ЧК, реввоенсовет, экспроприация).

Завершим мы статью праздничным настроем. Главное торжество СССР - 7 ноября, годовщину Великой Октябрьской социалистической революции, сменил сегодня восстановленный праздник 4 ноября, который был учрежден династией Романовых как празднование Казанской иконы Божией Матери в память избавления Москвы и России от поляков в 1612 году. В постсоветское время произошла реституция дореволюционного праздника сначала как День согласия и примирения, а затем как День народного единства. В условиях глобализации жизненно необходима национальная идентификация. Методология ХМСП дает теоретическую основу социальному конструированию и смысловому наполнению общенародных скреп. $\diamond$

1. Демичев А. А. О понятийном аппарате хронодискретного моногеографического сравнительного правоведения // Актуальные проблемы и перспективы развития научной школы Хронодискретного моногеографического сравнительного правоведения : сборник научных трудов по материалам Второй всероссийской научной конференции. Нижний Новгород : НИУ РАНХиГС, 2019. С. 9-19.

2. Тимошук А. С. ХМСП: метафизика, философия, системогенетика // Актуальные проблемы и перспективы развития научной школы Хронодискретного моногеографического сравнительного правоведения : сборник научных трудов по материалам Второй всероссийской научной конференции. Н. Новгород : НИУ РАНХиГС, 2019. С. 19-25.

3. Ивин А. А. Три русских революции в ХХ веке // Революция и эволюция: модели развития в науке, культуре, социуме : сборник научных статей. Н. Новгород : Изд-во Нижегородского госуниверситета им. Н. И. Лобачевского, 2017. С. 284. 
4. Трофимова Н. Н. Пенитенциарная система Российской Империи в эпоху общественно-политического кризиса революционного периода (1905 - февраль 1917 гг.) // Право и власть: основные модели вазаимодействия в многополярном мире : сборник трудов Международной научной конференции. Воронеж : Наука-Юнипресс, 2017. С. 450-454.

5. Тробимова Н. Н. 12 марта - день работника уголовно-исполнительной системы: история праздника // Пенитенциарное право: юридическая теория и правоприменительная практика. 2017. № 1. С. 33.

6. Дудырев Ф. Ф. Разработка и принятие уголовного уложения 1903 г. // Актуальные проблемы экономики и права. 2009. № 4. С. 193-198.

7. Тробимова Н. Н., Щепетов К. М. Исторические традиции формирования общественного контроля за постпенитенциарной адаптацией осужденных в Российской Империи (конец XIX - начало XX в.) // Пенитенциарное право: юридическая теория и правоприменительная практика. 2016. № 1. С. 101-106.

8. Тробимова Н. Н., Рубцов Д. И. Международные тюремные конгрессы как форма сотрудничества в сфере исполнения уголовных наказаний (историко-правовой аспект) // Ведомости уголовно-исполнительной системы. 2017. № 5. С. 24-27.

9. Илюхин А. В. Перспективные направления исследований по истории уголовно-исполнительной системы России через призму научной школы хронодискретного моногеографического сравнительного правоведения // Актуальные проблемы и перспективы развития научной школы Хронодискретного моногеографического сравнительного правоведения : сборник научных трудов по материалам Второй всероссийской научной конференции. Н. Новгород : НИУ РАНХиГС, 2019. С. 253-263.

10. Тимощук А. С. Революция и гражданская война в России как инструменты модернизации общества // Революция 1917 года и Гражданская война: региональное измерение общероссийских процессов : материалы Всероссийского круглого стола, посвященного 100-летию Великой Российской Революции и 95-летию окончания Гражданской войны (7 декабря 2017 г.). Курган : Изд-во Курганского государственного университета, 2017. С. 3-11.

11. Панова Е. А. Политика «ликвидации кулачества как класса» и ее проведение в Центрально-Черноземной области в 1929-1932 годах : автореф. дис. ... канд. ист. наук : 07.00.02. Липецк : Липецкий государственный педагогический университет, 2007. 21 с.

12. Королёва Е. В. Организационно-правовые основы коллективизации сельского хозяйства в Советской России в 20-30-е годы XX века : автореф. дис. ... канд. юрид. наук : 12.00.01. Курск : Юго-Западный государственный университет, 2013.21 с.

13. Мусорина О. А., Сорокина С. Г. Русский язык в советский и постсоветский период : монография. Пенза : ПГУАС, 2014. С. 35-36.

14. Бельх Н. Ю. Экономика ГУЛАГА как система подневольного труда (на материалах Вятлага, 1938-1953 гг.). М. : Фонд «Президентский центр Б. Н. Ельцина» : РОССПЭН, 2011. 293 с.

15. ГУЛАГ: экономика принудительного труда / отв. ред.: Л. И. Бородкин, П. Грегори, О. В. Хлевнюк. М. : РОССПЭН : Фонд Первого Президента России Б. Н. Ельцина, 2008. 315 с.

16. Бородкин Л. И., Эрти С. Структура и стимулирование принудительного труда в ГУЛАГе: Норильлаг, конец 1930-х - начало 1950-х гг. // Экономическая история. Ежегодник. 2003. М. : РОССПЭН, 2004. С. 177-233.

17. Кустышев А. Н. Промышленное строительство в системе ГУЛАГа на Европейском Севере России в 1930 - начале 1940-х годов: масштабы, тенденции, проблемы // Историческая и социально-образовательная мысль. Т. 7, № 6. Ч. 2. 2015. С. 1-5.

18. Кузьмин С. И. Роль ГУЛАГа в карательной системе советского государства // Преступление, наказание, исправление (к 140-летию уголовно-исполнительной системы России и 85-летию Академии ФСИН России) : сборник тезисов выступлений и докладов участников IV Международного пенитенциарного форума. В 10 т. Рязань : Академия ФСИН России, 2019. C. 71-76. 
19. Горбунова М. М., Руби,ов Д. И., Трофимова Н. Н. Формирование общественного мнения о деятельности отечественной системы исполнения уголовных наказаний в советский период // Вестник Владимирского юридического института. 2018. № 2. С. 171-177.

1. Demichev, A. A. (2019) On the conceptual apparatus of chrono-discrete monogeographical comparative jurisprudence // Actual problems and prospects for the development of the scientific school of Chrono-discrete monogeographic comparative jurisprudence : a collection of scientific papers based on the materials of the Second All-Russian Scientific Conference. Nizhny Novgorod : Institute of Management of the Russian Presidential Academy of National Economy and Public Administration, pp. 9-19.

2. Timoschuk, A. S. (2019) HMSP: metaphysics, philosophy, systemogenetics // Actual problems and prospects for the development of the scientific school of Chronodiscrete monogeographic comparative jurisprudence : a collection of scientific papers based on the materials of the Second All-Russian Scientific Conference. Nizhny Novgorod : Institute of Management of the Russian Presidential Academy of National Economy and Public Administration, pp. 19-25.

3. Ivin, A. A. (2017) Three Russian revolutions in XX century// Revolution and evolution: models of development in science, culture, society : collection of scientific articles. Nizhny Novgorod : Publishing house of the Nizhny Novgorod State University named after N. I. Lobachevsky, p. 284.

4. Trofimova, N. N. (2017) Russian penitentiary system in the era of socio-political crisis of the revolutionary period (1905-February 1917) // Law and Power: Basic Models of Interaction in a Multipolar World : Proceedings of the International Scientific Conference. Voronezh : Nauka-Unipress, pp. $450-454$.

5. Trofimova, N. N. (2017) On March 12 - day of the worker penal system: holiday history // Penal law: legal theory and law enforcement practices. 1, 33.

6. Dudyrev, F. F. (2009) Development and adoption of the criminal code of 1903 // Actual Problems of Economics and Law. 4, 193-198.

7. Trofimova, N. N., Shchepetov, K. M. (2016) The historical traditions of public control formation over post-penitentiary adaptation of convicts in the Russian empire (late XIX - early XX century) // Penal law: legal theory and law enforcement practices. 1, 101-106.

8. Trofimova, N. N., Rubtsov, D. I. (2017) International penitentiary congresses as the form of cooperation in the sentence execution sphere (legal and historical aspects) // Bulletin of the penal system. $5,24-27$.

9. Ilyukhin, A. V. (2019) Promising areas of research on the history of the penal system of Russia through the prism of the scientific school of chrono-discrete monogeographical comparative jurisprudence // Actual problems and prospects for the development of the scientific school of Chronodiscrete monogeographic comparative jurisprudence : a collection of scientific works based on the materials of the Second All-Russian Scientific Conference. Nizhny Novgorod : Institute of Management of the Russian Presidential Academy of National Economy and Public Administration, pp. 253-263.

10. Timoschuk, A. S. (2017) Revolution and civil war in Russia as tools for modernizing the society // Revolution of 1917 and Civil War: regional dimension of all-Russian processes : materials of the AllRussian round table dedicated to the 100th anniversary of the Great Russian Revolution and the 95th anniversary of the end of the Civil War (December 7, 2017). Kurgan : Publishing house of Kurgan State University, pp. 3-11.

11. Panova, E. A. (2007) The policy of «liquidation of the kulaks as a class» and its implementation in the Central Black Earth region in 1929-1932 : abstract of thesis ... of Candidate of History : 07.00.02. Lipetsk : Lipetsk State Pedagogical University, p. 21.

12. Koroleva, E. V. (2013) Organizational and legal foundations of agricultural collectivization in Soviet Russia in the 20-30s of the XX century : abstract of thesis ... of Candidate of Law : 12.00.01. Kursk : South-Western State University, p. 21.

13. Musorina, O. A., Sorokina S. G. (2014) Russian language in the Soviet and post-Soviet period: monograph. Penza : Penza State University of Architecture and Construction, pp. 35-36. 
14. Belykh, N. Yu. (2011) The economy of the GULAG as a system of forced labor (based on materials from Vyatlag, 1938-1953). Moscow : Boris Yeltsin Presidential Center Foundation : ROSSPEN, p. 293.

15. Executive Editors Borodkin, L. I., Gregory, P., Khlevnyuk, O. V. (2008) GULAG: economics of forced labor. Moscow : ROSSPEN : Boris Yeltsin Presidential Center Foundation, $315 \mathrm{p}$.

16. Borodkin, L. I., Ertz, S. (2004) The structure and stimulation of gulag forced labour: norillag, late 1930s - early 1950s // Economic history. Yearbook. 2003. Moscow : ROSSPEN, pp. 177-233.

17. Kustyshev, A. N. (2015) Industrial building in the system of gulag in the European north of Russia in the 1930 - early 1940s: scope, trends and challenges // Historical and Social-Educational Idea. Vol. 7, 6. Part 2, 1-5.

18. Kuzmin, S. I. (2019) The role of the GULAG in the punitive system of the Soviet state // Crime, punishment, correction (to the 140th anniversary of the penal system of Russia and the 85th anniversary of the Academy of the Federal Penitentiary Service of Russia) : a collection of abstracts and reports participants of the IV International Penitentiary Forum. In 10 volumes. Ryazan : Academy of the FPS of Russia, pp. 71-76.

19. Gorbunova, M. M., Rubczov, D. I., Trofimova N. N. (2018) Formation of public opinion on the activity of domestic system of execution of criminal penalties in the soviet period // Bulletin of Vladimir Law Institute. 2, 171-177. 
DOI 10.51522/2307-0382-2021-229-6-32-44

УДК 343.241

\section{Е. Н. ФЕДОТОВА}

старший научный сотрудник научно-исследовательского отдела научного центра Академии ФСИН России, кандидат юридических наук, майор внутренней службы

Рязань

\section{EVGENIYA N. FEDOTOVA}

Senior Researcher of the Scientific Research Division of the Scientific Center of the Academy of the FPS of Russia, Candidate of Law, Major of the Internal Service

Ryazan

\section{Современное состояние практики применения уголовного наказания в виде лишения свободы на определенный срок В отношении несовершеннолетних}

\section{Current state of practical applying criminal punishment in the form of imprisonment for a certain period in relation to juveniles}

Аннотация. В статье проводится анализ уголовного наказания в виде лишения свободы на определенный срок в части его применения к несовершеннолетним. Рассматриваются уголовный, уголовно-исполнительный и криминологический аспекты, а также соотношение порядка применения указанного уголовного наказания с положениями международных стандартов в области отправления правосудия в отношении несовершеннолетних. Предметом статьи является статистическая отчетность Судебного департамента при Верховном Суде Российской Федерации, ФСИН России, МВД России, российское законодательство, положения международных нормативных правовых актов, научная литература по заявленной тематике. Цель исследования заключается во всестороннем анализе наказания в виде лишения свободы на определенный срок как вида наказания, при-
Abstract. The article analyzes the criminal punishment in the form of imprisonment for a certain period in terms of its application to juveniles. The article considers the criminal, penal and criminological aspects, as well as the correlation of the procedure for applying the specified criminal punishment with the provisions of international standards in the administration of juvenile justice. The subject of the article is the statistical reporting of the Judicial Department at the Supreme Court of the Russian Federation, the Federal Penitentiary Service of Russia, the Ministry of Internal Affairs of Russia, Russian legislation, provisions of international regulatory legal acts, scientific literature on the stated topic. The purpose of the study is to comprehensively analyze punishment in the form of imprisonment for a certain period of time as a type of punishment applied to juveniles, to identify problems in the practice of its appointment and 
меняемого в отношении несовершеннолетних, в выявлении проблем в практике его назначения и исполнения в отношении обозначенной категории лиц, а также в поиске возможных путей их устранения. Методологическую основу исследования составили статистический, сравнительно-правовой, системно-структурный методы, анализ, синтез, индукция и другие общенаучные методы.

Автором исследованы сущность и содержание лишения свободы, порядок его назначения несовершеннолетним, проанализировань данные судебной статистики. На основании статистических данных ФСИН России изучена практика организации исполнения наказания в виде лишения свободы в отношении лиц, не достигших совершеннолетия. Проведено криминологическое исследование личности несовершеннолетнего, осужденного к данному виду уголовного наказания, содержащегося в воспитательной колонии. Выявлены основные тенденции и особенности назначения лишения свободы несовершеннолетним и практики его исполнения, дана оценка эффективности данного вида наказания несовершеннолетних, сформулированы имеющиеся проблемы, предложены авторские пути их устранения.

В заключение автор приходит к выводу о том, что в целом практика применения лишения свободы в отношении несовершеннолетних не имеет критических проблем и соответствует требованиям международных нормативных правовых актов. Основной проблемой является слабая организация постпенитенциарного сопровождения несовершеннолетних, отбывших лишение свободы.

Ключевые слова: несовершеннолетний, лишение свободы, воспитательная колония, несовершеннолетний преступник, преступность несовершеннолетних, ресоциализация. execution in relation to the designated category of persons, as well as to find possible ways of eliminating such problems. The methodological basis of the research was made up of statistical, comparative legal, systemic and structural methods, analysis, synthesis, induction and other general scientific methods.

The author has investigated the essence and content of imprisonment, the procedure for its appointment to juveniles, analyzed the data of judicial statistics. On the basis of statistical data of the Federal Penitentiary Service of Russia, the practice of organizing the execution of sentences in the form of imprisonment in relation to underage persons has been studied. A criminological personality study of a juvenile convicted to this type of criminal punishment, held in an educational colony, has been carried out. The main tendencies and peculiarities of appointing imprisonment for juveniles and the practice of its implementation are revealed, the effectiveness of this type of punishment for juveniles is assessed, the existing problems are formulated, and the author's ways of eliminating them are proposed.

In conclusion, the author states that, in general, the practice of applying imprisonment to juveniles does not have critical problems and complies with the requirements of international normative legal acts. The main problem is the weak organization of post-penitentiary monitoring of minors who have served their imprisonment sentence.

Key words: juvenile, imprisonment, educational colony, juvenile delinquent, juvenile delinquency, re-socialization.

12.00.08 Уголовное право и криминология; уголовно-исполнительное право (юридические науки) Criminal law and criminology; penal law (legal sciences)

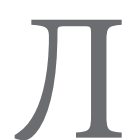

ишение свободы на определенный срок в соответствии со статьей 88 Уголовного кодекса Российской Федерации является одним из видов уголовных наказаний, назначаемых несовершеннолетним [1]. Исходя из логики конструкции части 1 указанной статьи, обозначенный вид уголовной репрессии является самой строгой мерой, которую можно применить в отношении лиц, не достигших совершеннолетия.

В соответствии с разъяснениями Верховного Суда Российской Федерации наказание несовершеннолетнему в виде лише- 
ния свободы назначается только в случае мотивированного признания судом невозможности его исправления без изоляции от общества [2].

Установленные уголовным законом нормы, регулирующие порядок применения к несовершеннолетним наказания в виде лишения свободы на определенный срок, изменялись законодателем трижды. Все изменения были направлены на ограничение применения рассматриваемого наказания в отношении несовершеннолетних, то есть на гуманизацию уголовной ответственности данной категории лиц и согласование национального законодательства с положениями международных нормативных правовых актов, регулирующих особенности отправления правосудия в отношении лиц, не достигших совершеннолетия.

В результате указанных изменений рассмотренные нормы уголовного закона, регулирующие порядок назначения несовершеннолетним наказания в виде лишения свободы на определенный срок, в целом соответствуют нормам международных нормативных правовых актов. Так, согласно статье 37 Конвенции ООН о правах ребенка, уголовное наказание в виде лишения свободы необходимо использовать как самую крайнюю меру [3]. Аналогичная норма закреплена и в статьях 1, 2 Правил $\mathrm{OOH}$, касающихся защиты несовершеннолетних, лишенных свободы [4], и в статье 19 Минимальных стандартных правил $\mathrm{OOH}$, касающихся отправления правосудия в отношении несовершеннолетних (Пекинские правила) [5].

С логичностью и целесообразностью приведенных норм невозможно не согласиться. Наказание в виде лишения свободы на определенный срок не должно являться основной формой реализации уголовной ответственности несовершеннолетних.
Как верно указывает Л. М. Алтынбаева, сущность анализируемого уголовного наказания заключается в изъятии несовершеннолетнего преступника из общества с применением обозначенных в законодательстве средств и методов исправления в специализированных учреждениях. Применение лишения свободы существенно ограничивает права осужденного, основным карательным элементом рассматриваемого наказания является изоляция осужденного от общества, в результате чего несовершеннолетний лишается свободы передвижения, возможности общения с людьми по своему выбору, что влечет за собой совокупность фоновых негативных последствий. Так, несовершеннолетний прерывает, помимо негативных, и позитивные социальные связи. В местах лишения свободы кроме положительного воздействия подросток испытывает и отрицательное влияние со стороны лиц, имеющих устойчивые криминальные и социально опасные установки [6].

Представляется интересным рассмотреть, как же складывается современная практика использования лишения свободы в отношении несовершеннолетних. Для этого необходимо проанализировать статистическую информацию.

По данным Судебного департамента при Верховном Суде Российской Федерации, в 2019 году к уголовной ответственности было привлечено 16858 несовершеннолетних, из них осуждено к лишению свободы 16,3 \% (2 755 человек), в 2020 году этот показатель составил 15,2 \% [7].

Проведя ретроспективный анализ статистических данных, увидим, что судебная практика в изучаемой области развивается крайне неоднородно. В 2008 году лишение свободы назначалось 23 \% лиц, не достигших совершеннолетия, в 2012-м - 16,1 \%, в $2015-$ м - 19,4 \%, в 2018-м - 19,7 \% [8]. 
В 2019, 2020 годах в зависимости от тяжести совершенного преступного деяния лишение свободы назначалось несовершеннолетним следующим образом:

- за преступления небольшой и средней тяжести - 27,7 \%;

- за тяжкие - 37,3\%;

- за особо тяжкие - 34,9\%.

Из представленных данных можно заключить, что уровень применения рассматриваемого наказания за преступления небольшой и средней тяжести является довольно высоким, что не в полной мере согласовывается с положением национального и международного законодательства. Однако следует отметить, что 45,6 \% несовершеннолетних осужденных к лишению свободы имели неснятую и непогашенную судимость, что вполне оправдывает выявленную судебную практику [7].

Социально-демографическая характеристика несовершеннолетних, осужденных к лишению свободы в 2019, 2020 годах, выглядит следующим образом: на лиц в возрасте от 14 до 15 лет приходится $21 \%$ от общего количества несовершеннолетних осужденных к лишению свободы; соответственно, на лиц в возрасте от 16 до 17 лет - $79 \%$. Среди осужденных к рассматриваемому виду наказания $5 \%$ - лица женского пола; 49 \% воспитывались в семье с одним родителем; вне семьи (детском доме, интернате) воспитывались около $10 \%$ несовершеннолетних. 56 \% несовершеннолетних осужденных к лишению свободы на момент совершения преступлений обучались; 2,4 \% работали; остальные осужденные не имели определенного рода занятий. $18 \%$ несовершеннолетних совершили преступления в состояния алкогольного либо наркотического опьянения. Более половины несовершеннолетних (56 \%) совершили преступные деяния в составе группы, причем 50 \% из них - с участием взрослых [7].
Далее уместно обратиться к ведомственной статистике ФСИН России, характеризующей лиц, содержащихся в воспитательных колониях. Прежде всего отметим уменьшение общего количества исправительных учреждений для несовершеннолетних. В 2010 году количество воспитательных колоний в России составляло 62 (с лимитом наполнения 19964 человека), в 2014-м - 41 (с лимитом 10916 человек), в 2019-м - 23 (с лимитом 5817 человек), в 2020-м - 18 (с лимитом 4676 человек), из них 2 воспитательные колонии для лиц женского пола. Среднесписочная численность осужденных, содержащихся в воспитательных колониях, в 2020 году составила 1017 человек (из них 68 лиц женского пола). То есть в настоящее время воспитательные колонии заполнены на $21,7 \%$ от допустимого лимита [9].

Однако сокращение воспитательных колоний и их отсутствие в некоторых субъектах России приводит к невозможности отбывания наказания несовершеннолетними вблизи места проживания их родственников, что усложняет поддержку социально полезных связей подростков и их последующую социальную адаптацию. Особенно остро этот вопрос стоит в отношении несовершеннолетних лиц женского пола - в связи с тем, что в настоящее время в России функционируют всего два учреждения для отбывания наказания данной категорией лиц.

В целом рассмотренные выше данные показывают, что в современной России формируются новые тенденции уголовной политики в отношении несовершеннолетних, базирующиеся на гуманизации ответственности и применении наказания в виде лишения свободы только в исключительных случаях.

Подавляющее большинство несовершеннолетних лиц отбывают лишение свободы 
сроком от двух до пяти лет. По видам совершенных ими преступных деяний показатели распределились следующим образом:

- в исправительных учреждениях содержатся за квалифицированные виды краж, грабежей, разбоев 27,5 \% несовершеннолетних осужденных;

- за убийства, причинение тяжких телесных повреждений различных степеней тяжести - 17,3\%;

- за изнасилование - 15 \% [9].

Также уместно отметить, что к рассматриваемой категории лиц активно применяется условно-досрочное освобождение: практически половина (49,5\%) освобождаются из воспитательных колоний условно-досрочно [9]. Такая тенденция заслуживает положительной оценки. Возможность условно-досрочного освобождения служит для подростка стимулом к исправлению и оказывает на него благоприятное воспитательное воздействие, способствует укреплению дисциплины и правопорядка.

Резюмируя, можно признать, что судебная практика в целом соответствует положениям международных стандартов.

Далее разберем пенитенциарную статистику более детально. В среднем в воспитательной колонии в настоящее время содержатся около 100 человек, что позволяет качественно организовывать воспитательную работу с осужденными и контролировать соблюдение режима отбывания наказания, осуществлять качественный надзор за осужденными и их охрану (к примеру, в Свердловской области среднесписочная численность контингента воспитательной колонии за 2019 год составила 122 человека, в Пермском крае - 101, в Новосибирской области - 83; при этом в Республике Дагестан - 11, в Воронежской области - 16, в Тульской области - 17) [10].

Также в воспитательных колониях отмечаются стабильно низкие показатели пе- нитенциарной преступности. Статистикой зафиксированы единичные факты совершения преступлений в воспитательных колониях: в 2017 году - 3, в 2018-м - 1, в 2019-м - 5, в 2020-м - 0. Уровень нарушения порядка отбывания наказаний на 1000 человек за 2019 год равнялся 868 случаям, что составляет менее одного нарушения на несовершеннолетнего осужденного за год. В 2020 году этот показатель опустился до нуля [9].

Следует отметить отсутствие фактов злостного нарушения порядка отбывания лишения свободы в воспитательных колониях, в том числе фактов употребления алкогольных напитков либо наркотических средств и психотропных веществ за последние девять лет [9].

На основании приведенных данных можно констатировать, что в воспитательных колониях удалось достичь некоего порядка, организовать процесс отбывания данного вида наказания так, что в них фактически отсутствует преступность, сведены к минимуму нарушения порядка отбывания наказания и нарушения прав данной категории осужденных сотрудниками колоний.

Несмотря на выявленные положительные изменения в практике применения лишения свободы к несовершеннолетним, в настоящее время не теряет актуальности вопрос постпенитенциарной адаптации подростков, отбывших анализируемое уголовное наказание.

М. Н. Садовникова и И. Р. Мокеев отмечают, что даже примерные данные о повторной преступности несовершеннолетних, отбывших лишение свободы, позволяют предположить достаточно высокий уровень повторной преступности [11], что является вполне закономерным явлением: ведь сформировать в заключении здоровую, социально ориентированную личность невозможно. 
Как уже отмечалось выше, полноценная статистика по данному вопросу отсутствует. Приведем статистические данные, которыми оперирует Судебный департамент при Верховном Суде Российской Федерации. В 2018 году доля осужденных несовершеннолетних, ранее приговоренных к реальному лишению свободы, составила 3,5 \% от общего числа осужденных несовершеннолетних; в 2019-м - 3,8 \%; в 2020-м - 3,7 \%. Среди несовершеннолетних, осужденных к лишению свободы, доля лиц, ранее осуждавшихся к лишению свободы, в 2018-2020 годах составила 19 \% [7]. Иными словами, каждый пятый подросток, освободившийся из воспитательной колонии, возвращается туда вновь до достижения совершеннолетия. Подчеркнем, что приведенные статистические данные демонстрируют только постпенитенциарную преступность не достигших совершеннолетия лиц, ранее отбывавших лишение свободы, то есть подростков строго в возрасте от 14 до 18 лет. Каков процент лиц, совершивших повторное преступление в совершеннолетнем возрасте после отбытия наказания в воспитательной колонии, статистикой не отмечается, однако на основании приведенных данных можно предположить, что достаточно большой.

В настоящее время фактически отсутствуют государственные учреждения, выполняющие функции социального контроля и оказывающие освободившимся лицам помощь в реабилитации, не создана необходимая правовая база, регламентирующая порядок оказания помощи несовершеннолетним, освободившимся из воспитательных колоний, и членам их семей. Имеющиеся нормы, прописанные в Уголовно-исполнительном кодексе Российской Федерации (УИК РФ), во многом носят декларативный характер.
Кроме того, согласно части 1 статьи 3 Федерального закона от 06.04.2011 № 64-Ф3 «Об административном надзоре за лицами, освобожденными из мест лишения свободы», административный надзор устанавливается только в отношении совершеннолетнего лица [12]. К несовершеннолетним, отбывшим наказания в виде лишения свободы, не применяется административный надзор, который по своей сути является одним из методов профилактики рецидивной и постпенитенциарной преступности.

Частью 2 статьи 1 УИК РФ установлено, что одной из задач уголовно-исполнительного законодательства является «оказание осужденным помощи в социальной адаптации». При этом обращает на себя внимание то, что порядок и условия исполнения и отбывания наказаний детально регулируются нормами УИК РФ, тогда как порядок оказания помощи освободившимся осужденным практически в кодексе не прописан, а небольшое количество имеющихся статей, регулирующих общественные отношения в данной сфере, носят в основном бланкетный и отсылочный характер.

Конечно, логика в этом есть, так как работа с несовершеннолетними лицами, освобожденными из мест лишения свободы, выходит за пределы компетенции уголовно-исполнительной системы и уголовно-исполнительного законодательства. Однако и на государственном уровне отсутствует единый слаженный механизм оказания помощи таким лицам иными органами власти, государственными и общественными организациями.

Проведенный нами мониторинг центров социальной адаптации граждан в субъектах Российской Федерации показал их явную количественную недостаточность. Так, на сегодняшний день в Рос- 
сии функционируют 175 таких центров, финансирующихся либо из бюджетных средств субъектов, либо за счет пожертвований [13]. Такие центры имеются не в каждом регионе, а их лимиты наполнения не позволяют предоставить помощь всем нуждающимся.

Криминологические и психологические исследования пребывания осужденных подростков в местах заключения констатируют, что продолжительная изоляция от общества и семьи, режим отбывания наказания, криминальная субкультура, еще присутствующая в воспитательных колониях, усугубляют имеющиеся девиации несовершеннолетних преступников, усиливают процесс их личностной деформации, что в итоге провоцирует последующее преступное поведение.

Р. В. Чиркина, А. А. Галушкин отмечают, что ситуацию осложняет тот факт, что большое количество осужденных подростков освобождаются из мест лишения свободы, достигнув совершеннолетия, в связи с чем государственные учреждения не оказывают им специализированной поддержки [14].

В нашей стране организация профилактики рецидива преступлений возложена в основном на органы внутренних дел, сотрудники которых из-за специфики службы не имеют необходимых профессиональных, кадровых и материальных возможностей для решения этой проблемы.

Далее, соглашаясь с мнением Р. В. Чиркиной, А. А. Галушкина, отметим, что для уменьшения рецидивной преступности необходим комплексный подход с разработкой социальных, правовых, политических узкопрофильных программ и созданием специализированного государственного института постпенитенциарного сопровождения, как это сделано многими развитыми странами [14].
В заключение будет справедливым отметить, что в России происходит спад преступной деятельности лиц, не достигших совершеннолетнего возраста: по данным МВД России, в течение последних пяти лет имеется стабильная положительная динамика в состоянии преступности несовершеннолетних, как в абсолютных показателях, так и в относительных, а удельный вес данного вида преступности в общем числе выявляемых преступлений не превышает 4,5 \% [15]. Приведенные статистические данные свидетельствуют о том, что проводимая государством уголовная и уголовно-исполнительная политика, направленная на гуманизацию уголовной ответственности лиц, совершивших преступления в несовершеннолетнем возрасте, в целом имеет позитивные результаты.

Однако, несмотря на положительные изменения в анализируемой сфере, обществу, государству и юридической науке особое внимание необходимо уделять не вопросам дальнейшей гуманизации уголовной ответственности несовершеннолетних, не порядку исполнения уголовных наказаний в отношении обозначенной категории лиц, а социальной профилактике подростковой преступности и постпенитенциарному сопровождению несовершеннолетних, отбывших наказание.

Системный подход к выявленным проблемам, возникающим в процессе исполнения лишения свободы в отношении несовершеннолетних, продуманная организация поддержки несовершеннолетних преступников после освобождения от отбывания наказания будут способствовать дальнейшему сокращению преступности несовершеннолетних лиц, а также улучшению ситуации с рецидивной и профессиональной преступностью в нашем государстве в целом. $\diamond$ 
В прошлом номере журнала была опубликована статья о том, как перевести военную пенсию в Почта Банк - один из крупнейших банков с госучастием. Многие из пенсионеров и сотрудников ФСИН уже сделали это или собираются. В адрес редакции пришло много вопросов, за ответами мы обратились к специалистам Почта Банка.

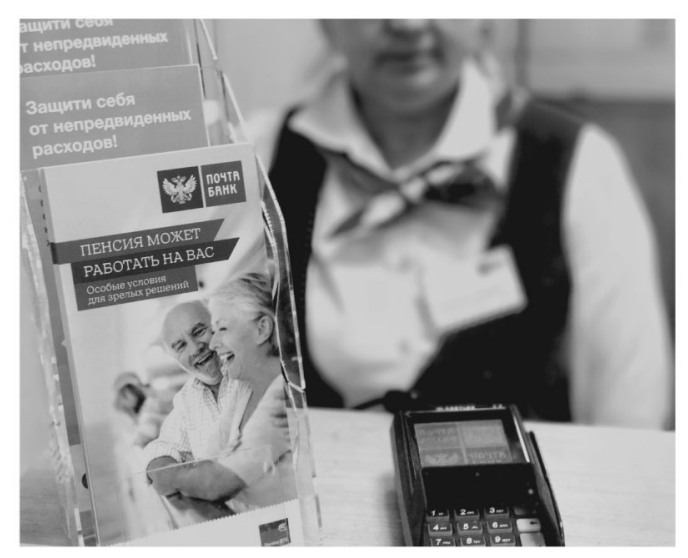

\section{СОХРАНИТЬ И ПРЕУМНОЖИТЬ}

ОТВЕЧАЕМ НА ГЛАВНЫЕ ВОПРОСЫ ПРО ВОЕННУЮ ПЕНСИЮ

\section{Если я сейчас получаю военную пенсию в другом банке, могу ли я по своему желанию перевести ее? Нужно ли для этого согласие руководства?}

По действующему законодательству каждый из нас может выбрать банк для получения пенсии. Для перевода вашей пенсии нужно всего один раз прийти в Почта Банк, открыть счет и получить к нему карту. Потом передать заявление о переводе пенсии в пенсионный отдел вашего ведомства. Кстати, заявление можно вырезать из этого журнала и заполнить.

\section{Сколько стоит перевести пенсию в Почта Банк?}

Счет в Почта Банке откроют совершенно бесплатно, как и выпустят карту к нему.

По долгу службы я нахожусь в небольшом городке, где нет отделений банков. Какие у меня возможности открыть счет для получения военной пенсии?

Вы можете открыть такой счет в любой из 19 тысяч точек обслуживания банка по всей стране. Большинство из них расположены на базе почтовых отделений. Наверняка почта найдется и рядом с вами. 


\section{Сколько у Почта Банка банкоматов, где можно снять пенсию с карты?}

Снять деньги с карты без всякой комиссии можно в одном из 19500 банкоматов Почта Банка и ВТБ по всей стране или в ближайшем почтовом отделении. Те, кто получают в банке пенсию, могут снимать до 10 тысяч рублей в месяц без комиссии в любом банкомате страны. А еще снять наличные с карты можно с помощью специальных POS-терминалов во всех почтовых отделениях страны.

\section{Я сейчас оплачиваю «коммуналку» с комиссией. А как в Почта Банке с этим?}

Все клиенты банка оплачивают ЖКУ без комиссии. Также можно оплатить мобильную связь, городской телефон и интернет, государственные услуги и штрафы, образование, сделать перевод.

\section{Какие еще преимущества я получу, переведя пенсию в Почта Банк?}

Мы стараемся использовать все надежные и эффективные финансовые инструменты для увеличения пенсионных накоплений сотрудников и ветеранов ФСИН. Банк начисляет до 5\% годовых на минимальный остаток средств на пенсионном счете, что выше средних рыночных ставок по депозитам. Пенсия, поступив на счет, сразу начинает работать и приносить доход. Важно, что деньги можно тратить, они не «замораживаются», как на вкладе. Для военных пенсионеров предусмотрены повышенные ставки по вкладам и льготные по кредитам.

\section{Дает ли карта банка льготы при покупках и какие?}

За все покупки по карте в аптеках, на автозаправках, оплату железнодорожных билетов банк возвращает $3 \%$ на счет бонусами (1 бонус = 1 рубль). Если подключить программу «Мультибонус», то бонусы будут начисляться за все покупки по карте. По программе «Мое здоровье» скидка на лекарства доходит до 70\%. Разве плохо?

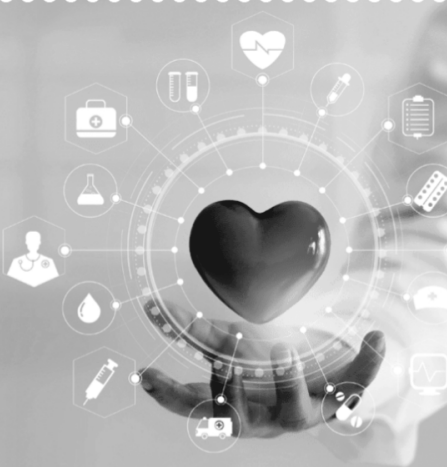

\section{Какие еще есть сервисы у банка?}

Мы бесплатно подключаем «своим» пенсионерам сервис «Линия заботы», где специалисты консультируют по юридическим, социальным вопросам, проблемам со здоровьем. У банка удобное и современное мобильное приложение, где абсолютно все услуги можно получить удаленно. 
От

(Ф. И. О.)

(почтовый индекс, район, телефон)

\section{ЗАЯВЛЕНИЕ О ПОРЯДКЕ ВЫПЛАТЫ}

\section{ПЕНСИИ (ПОСОБИЯ)}

Прошу причитающуюся мне пенсию (пособие) переводить на счет №

Наименование банка $\mathrm{AO}$ «Почта Банк»

БИК 044525214 номер корреспондентского счета 30101810245250000214 КПП 997950001 ИНН 3232005484

расположенный по адресу 107061, г. Москва, Преображенская пл., д. 8

Личная подпись получателя

(фамилия, инициалы)

"—”_ 20_ г.




\title{
ПЕРЕВЕДИТЕ ВОЕННУЮ ПЕНСИЮ В ПОЧТА БАНК
}

\begin{abstract}
Это ваше право и ваш выбор, где получать военную пенсию, но получение военной пенсии в Почта Банке - это не только удобно, но и выгодно!
\end{abstract}

\section{Специальные преимущества}

Военным пенсионерам, получающим военную пенсию на счёт в Почта Банке, автоматически доступны специальные условия и преимущества, например:

$\%$ Получение до $5 \%$ на остаток по «Сберегательному счёту».

Оплата без комиссии коммунальных услуг, мобильной связи, телефонии, интернета, ТВ,

транспорта, штрафов, налогов и др. в любом отделении Почта Банка с помощью сотрудника, через банкомат или в Почта Банк Онлайн.

Снятие наличных без комиссии - до 10000 руб. ежемесячно более чем в 19500 банкоматах Почта Банка и банков группы ВТБ и более чем в 54000 терминалов Почта Банка в отделениях почтовой связи, а также во всех других банкоматах страны.

\section{Путь военного пенсионера для перевода военной пенсии в Почта Банк}

Готовы? Приходите в Почта Банк или вызовите сотрудника банка на дом!

1. Посетите ближайший офис Почта Банка.

2. Мы откроем Вам «Сберегательный счёт» и выдадим карту «Мир» к нему.

3. Мы поможем Вам заполнить заявление о переводе военной пенсии.

4. Вам необходимо будет направить заявление для получения военной пенсии в Почта Банке в пенсионный отдел ведомства, где Вы проходили службу. Вы можете это сделать лично, придя в ведомство, или отправить заявление в конверте по почте.

5. Военное ведомство (пенсионный отдел) передаст новые реквизиты в банк, через который осуществляется выплата пенсии. 
1. Уголовный кодекс Российской Федерации от 13.06.1996 № 63-ФЗ. Доступ из СПС «КонсультантПлюс».

2. О судебной практике применения законодательства, регламентирующего особенности уголовной ответственности и наказания несовершеннолетних : пост. Пленума Верховного Суда Рос. Федерации от 01.02.2011 № 1 (ред. от 29.11.2016) // Бюллетень Верховного Суда Рос. Федерации. 2011. № 4.

3. Конвенция ООН о правах ребенка : принята резолюцией 44/25 Генеральной ассамблеи OОН от 20.11.1989 // Организация Объединенных Наций : [сайт]. URL: https://www.un.org/ru/ documents/decl_conv/conventions/childcon.shtml (дата обращения: 28.04.2021).

4. Правила ООН, касающиеся защиты несовершеннолетних, лишенных свободы : приняты резолюцией 45/113 Генеральной ассамблеи ООН от 14.12.1990 // Организация Объединенных Наций : [сайт]. URL: https://www.un.org/ru/documents/decl_conv/conventions/juveniles_liberty. shtml (дата обращения: 28.04.2021).

5. Минимальные стандартные правила $\mathrm{OOH}$, касающиеся отправления правосудия в отношении несовершеннолетних (Пекинские правила) : приняты резолюцией 40/33 Генеральной ассамблеи ООН от 29.11.1985 // Организация Объединенных Наций : [сайт]. URL: https://www. un.org/ru/documents/decl_conv/conventions/beijing_rules.shtml (дата обращения: 28.04.2021).

6. Алтынбаева Л. М. Лишение свободы в отношении несовершеннолетних: проблемы применения и пути их совершенствования // Вестник Омского университета. Серия «Право». 2009. № 1. С. 91-96.

7. Сводные статистические сведения о состоянии судимости в России за 2018, 2019, 2020 годы. Форма № 12 : Отчет об осужденных, совершивших преступления в несовершеннолетнем возрасте // Судебный департамент при Верховном Суде Российской Федерации : [сайт]. URL: http://www.cdep.ru/index.php?id=79 (дата обращения: 05.05.2021).

8. Основные статистические показатели состояния судимости в России за 2008-2019 годы // Судебный департамент при Верховном Суде Российской Федерации : [сайт]. URL: http: //www.cdep.ru/index.php?id=79\&item=2074 (дата обращения: 21.12.2020).

9. Характеристика лиц, содержащихся в воспитательных колониях для несовершеннолетних // ФСИН России : [сайт]. URL: https://fsin.gov.ru/structure/inspector/iao/statistika/Xar-ka\%20 v\%20VK/ (дата обращения: 10.03.2021).

10. Воспитательные колонии. Сведения о состоянии преступности среди лиц, содержащихся в учреждениях УИС за декабрь 2019 года // Форма 2 УИС. Доступ из АИС «Статистика УИС» (дата обращения: 11.01.2021).

11. Садовникова М. Н., Мокеев И. Р. Лишение свободы несовершеннолетних: некоторые вопросы эффективности // Сибирский юридический вестник. 2016. № 4. С. 46-52.

12. Об административном надзоре за лицами, освобожденными из мест лишения свободы : федер. закон от 06.04.2011 № 64-Ф3. Доступ из СПС «КонсультантПлюс».

13. Реестр центров социальной адаптации граждан в субъектах Российской Федерации // ГУФСИН России по Новосибирской области : [сайт]. URL: http://54.fsin.gov.ru/reestr-tsentrovsotsialnoy-adaptatsii-grazhdan/ (дата обращения: 22.12.2020).

14. Чиркина Р. В., Галушкин А. А. Удержание несовершеннолетних от повторных преступлений // Вестник РУДН. Серия «Юридические науки». 2012. № 4. С. 123-133.

15. Состояние преступности // МВД России : [сайт]. URL: https://xn--blaew.xn--plai/ folder/101762 (дата обращения: 22.12.2020).

1. The Criminal Code of the Russian Federation of 13.06.1996 No. 63-FZ. Access from Legal Reference System «Consultant Plus».

2. On judicial practice of applying the legislation regulating the peculiarities of criminal liability and punishment of juveniles : Resolution of the Plenum of the Supreme Court of the Russian Federa- 
tion of 01.02.2011 No. 1 (as amended on 29.11.2016) // Bulletin of the Supreme Court of the Russian Federation. 2011. No. 4.

3. Convention on the Rights of the Child : adopted by General Assembly resolution 44/25 of 20.11.1989 // United Nations : [site]. URL: https://www.un.org/ru/documents/decl_conv/conventions/ childcon.shtml [Accessed 28 ${ }^{\text {th }}$ April 2021].

4. UN Rules for the Protection of Juveniles Deprived of their Liberty : adopted by General Assembly resolution 45/113 of 14.12.1990 // United Nations : [site]. URL: https://www.un.org/ru/documents/ decl_conv/conventions/juveniles_liberty.shtml [Accessed 28 ${ }^{\text {th }}$ April 2021].

5. UN Standard Minimum Rules for the Administration of Juvenile Justice (Beijing Rules) : adopted by General Assembly resolution 40/33 of 29.11.1985 // United Nations : [site]. URL: https://www. un.org/ru/documents/decl_conv/conventions/beijing_rules.shtml [Accessed 28 $8^{\text {th }}$ April 2021].

6. Altynbaeva, L. M. (2009) Imprisonment in relation to juveniles: problems of application and ways to improve them // Herald of Omsk University. Series «Law». 1, 91-96.

7. Summary statistical information on the state of convictions in Russia for 2018, 2019, 2020. Form No. 12 : Report on convicts who committed crimes as minors // Judicial Department at the Supreme Court of the Russian Federation : [site]. URL: http://www.cdep.ru/index.php?id=79 [Accessed $5^{\text {th }}$ May 2021].

8. The main statistical indicators of the state of convictions in Russia for 2008-2019 // Judicial Department at the Supreme Court of the Russian Federation : [site]. URL: http://www.cdep.ru/index. php?id=79\&item $=2074$. [Accessed $21^{\text {st }}$ December 2020].

9. Characteristics of persons held in juvenile educational colonies // FPS of Russia : [site]. URL: https://fsin.gov.ru/structure/inspector/iao/statistika/Xar-ka\%20v\%20VK/ [Accessed $10^{\text {th }}$ March 2021].

10. Educational colonies. Information on the state of crime among persons held in penal institutions for December 2019 // Form 2 of the Penal System. Access from Automatic Information System «Penal system Statistics» [Accessed $11^{\text {th }}$ January 2021].

11. Sadovnikova, M. N., Mokeyev, I. R. (2016) Deprivation of liberty of the minors: some issues of effectivness // Siberian law herald. 4, 46-52.

12. On the administrative supervision of persons released from prisons : Federal Law of 06.04.2011 No. 64-FZ. Access from Legal Reference System «Consultant Plus».

13. Register of centers for social adaptation of citizens in the constituent entities of the Russian Federation // FPS of Russia Main Department in the Novosibirsk Region : [site]. URL: http://54.fsin.gov. ru/reestr-tsentrov-sotsialnoy-adaptatsii-grazhdan/ [Accessed $22^{\text {nd }}$ December 2020].

14. Chirkina, R. V., Galushkin, A. A. (2012) Detention of minors from repeated crimes // RUDN Journal of Law. 4, 123-133.

15. The state of crime // Ministry of Internal Affairs of Russia : [site]. URL: https://xn--blaew.xn-plai/folder/101762 [Accessed 22 ${ }^{\text {nd }}$ December 2020]. 
DOI 10.51522/2307-0382-2021-229-6-45-55

УДК 657

\section{Я. И. МОШНЯКОВА}

главный специалист отделения планирования и контроля научно-исследовательских и опытно-конструкторских работ отдела планирования и контроля научноисследовательских и опытно-конструкторских работ, финансово-экономической работы и государственных закупок административно-управленческого персонала ФКУ НИИИТ ФСИН России

Тверь

\section{YANA I. MOSHNYAKOVA}

Chief Specialist of the Division of Planning and Control of Research and Development Work of the Department of Planning and Control of Research and Development Work, Financial and Economic Work and Public Procurement of Administrative and Managerial Personnel of the Federal Governmental Institution «Scientific Research Institute of Information Technologies of the FPS of Russia»

Tver

\section{Ю. А. КОРНИЛОВА}

научный сотрудник отделения планирования и контроля научно-исследовательских и опытно-конструкторских работ отдела планирования и контроля научноисследовательских и опытно-конструкторских работ, финансово-экономической работы и государственных закупок административно-управленческого персонала ФКУ НИИИТ ФСИН России, старший лейтенант внутренней службы

Тверь

\section{YULIA A. KORNILOVA}

Researcher of the Division of Planning and Control of Research and Development Work of the Department of Planning and Control of Research and Development Work, Financial and Economic Work and Public Procurement of Administrative and Managerial Personnel of the Federal Governmental Institution «Scientific Research Institute of Information Technologies of the FPS of Russia», Senior Lieutenant of the Internal Service

Tver

\section{Н. В. РЯБОВА}

ведущий научный сотрудник отделения планирования и контроля научноисследовательских и опытно-конструкторских работ отдела планирования и контроля научно-исследовательских и опытно-конструкторских работ, финансово-экономической работы и государственных закупок административно-управленческого персонала ФКУ НИИИТ ФСИН России

Тверь 


\section{NATALIA V. RYABOVA}

Leading Researcher of the Division of Planning and Control of Research and Development Work of the Department of Planning and Control of Research and Development Work, Financial and Economic Work and Public Procurement of Administrative and Managerial Personnel of the Federal Governmental Institution «Scientific Research Institute of Information Technologies of the FPS of Russia»

Tver

\section{Ю. Д. КОЗЛОВ}

старший научный сотрудник отделения планирования и контроля научно-

исследовательских и опытно-конструкторских работ отдела планирования и контроля научно-исследовательских и опытно-конструкторских работ, финансово-экономической работы и государственных закупок административно-управленческого персонала ФКУ НИИИТ ФСИН России

Тверь

\section{YURI D. KOZLOV}

Senior Researcher of the Division of Planning and Control of Research and Development Work of the Department of Planning and Control of Research and Development Work, Financial and Economic Work and Public Procurement of Administrative and Managerial Personnel of the Federal Governmental Institution «Scientific Research Institute of Information Technologies of the FPS of Russia»

Tver

\section{Законодательное регулирование учета результатов научно-исследовательских и опытно-конструкторских работ}

\section{Legislative regulation of the results of research and experimental design works}

Аннотация. Представленная статья посвящена исследованию вопросов учета результатов научно-исследовательских и опытно-конструкторских работ в учреждениях уголовно-исполнительной системы. Цель исследования заключается в обращении к служебной научно-технической информации уголовно-исполнительной системы как к объекту правового регулирования. Научная и практическая значимость работы заключается в ее последующей применимости при правовом регулировании деятельности в организациях. Проведение исследования основано на эмпири-
Abstract. The presented article studies the issues of accounting the results of research and development work in the institutions of the penal system. The purpose of the study is to refer to the official scientific and technical information of the penal system as an object of legal regulation. The scientific and practical significance of the work lies in its subsequent applicability in the legal regulation of activities in organizations. The research is based on the empirical method of cognition. The descriptive method of normative legal documents regulating the scientific activity in the penal system is used. The authors of the article 
ческом методе познания. Использован описательный метод нормативных правовых документов, регулирующих научную деятельность в уголовно-исполнительной системе. Авторы статьи резюмируют необходимость создания единой базы данных научно-исследовательских и опытно-конструкторских работ в ведомстве. Практическая ценность материалов, представленных в данной статье, заключается в возможности создания на их основе единой базы данных для учета результатов интеллектуальной деятельности. Внутренний учет научно-технической документации оптимизирует планирование и контроль научно-исследовательских и опытно-конструкторских работ, увеличит объем внедрения разработок, расширит возможности обмена опытом. Создание ведомственной автоматизированной системы, действующей на основе количественных показателей, в результате будет способствовать повышению качества научного обеспечения и эффективности работы всей пенитенциарной системы.

Ключевые слова: научная деятельность, научно-техническая деятельность, научно-техническая информация, научно-технический результат, государственное регулирование, результаты научно-технической деятельности, результат интеллектуальной деятельности. summarize the need to create a unified database of research and development activities in the Service. The practical value of the materials presented in this article lies in the possibility of creating on their basis a single database for accounting the results of intellectual activity. Internal accounting of scientific and technical documentation will optimize the planning and control of research and development work, increase the volume of implemented developments, and expand the opportunities for exchange of experience. The creation of a departmental automated system operating on the basis of quantitative indicators, as a result, will help to improve the quality of scientific support and the efficiency of the entire penitentiary system.

Key words: scientific activity, scientific and technical activity, scientific and technical information, scientific and technical result, state regulation, results of scientific and technical activity, the result of intellectual activity.

12.00.14 Административное право, административный процесс (юридические науки) Administrative Law; administrative process (legal sciences)

Одной из целей современной политики государства является развитие, эффективное внедрение и рациональное использование научно-технического потенциала. Рост экономики государства зависит как от разработок науки и техники, так и от планирования, учета и внедрения полученных научных результатов, имеющих общегосударственное значение. Совокупность перечисленных мероприятий необходима для централизованной обработки и учета информации и децентрализованного ее использования. Исключительно организационный подход к учету и передаче научных результатов влияет на качественное выполнение исследований и передачу полученных результатов заказчикам для дальнейшего внедрения и использования.

Создание единой системы государственного учета информации, включающей со- вокупность научно-технических библиотек, способствует эффективному использованию государственных ресурсов. Автоматизированный учет результатов научных исследований служит основным механизмом в развитии образовательных и научных организаций.

Научные и образовательные организации высшего образования, Федеральная служба исполнения наказаний (ФСИН России) в ходе своей деятельности формируют значительный объем научных знаний. Знания продуцируются в процессе проведения индивидуальных исследований как научными и научно-педагогическими работниками ведомства, так и научными коллективами данных организаций в результате проведения плановых и внеплановых научно-исследовательских и опытно-конструкторских работ (далее - НИОКР). 
Как правило, НИОКР проводятся в уголовно-исполнительной системе (УИС) на основании заявок заказчиков научной и научно-технической продукции при постоянном взаимодействии с учреждениями и органами УИС, а также с научными, образовательными и иными организациями других министерств и ведомств на основе совместной разработки комплексных проблем, координации тематики исследований, заключения договоров, обмена полученными результатами согласно приказу ФСИН России от 02.09.2020 № 606 «О научном обеспечении деятельности уголовно-исполнительной системы» (далее Приказ № 606) [1]. Научная и научно-техническая деятельность может осуществляться и по инициативе научно-исследовательских и образовательных организаций ФСИН России.

Итоги научных и научно-технических работ являются результатами интеллектуальной деятельности (далее - РИД) работников организации УИС и становятся служебными РИД. Служебные РИД формируют интеллектуальную собственность организации, являются объектом управления, а также выступают важнейшим компонентом при выполнении ведомством своих функций. Таким образом, охрана интеллектуальной собственности - важный вопрос для стабильного развития научной организации и ведомства в целом.

В связи с увеличением объема научных работ и практических результатов возникает необходимость создания и регулирования учета РИД, полученных в ходе выполнения НИОКР. Учет результатов интеллектуальной деятельности выступает основой для дальнейшего создания и внедрения инновационных идей, что помогает организациям найти верные решения для выполнения обширного перечня специальных задач [2].

В настоящее время учет РИД, созданных в учреждениях ФСИН России, осуществляют федеральное казенное учреждение «Научно-исследовательский институт Федеральной службы исполнения наказаний» (ФКУ НИИ ФСИН России) и федеральное казенное учреждение «Научно-исследовательский институт информационных технологий Федеральной службы исполнения наказаний» (далее -
ФКУ НИИИТ ФСИН России, Институт). Учет ведется только по тематикам исследований.

По этой причине доступ к знаниям, полученным в ходе выполнения НИОКР для потенциальных потребителей внутри ведомства, не является открытым. Эта недоступность связана с тем, что научные и научно-технические результаты после окончания работ находятся у организации-исполнителя и непосредственно у заказчика работы, которыми могут выступать структурные подразделения ФСИН России, учреждения, непосредственно подчиненные ФСИН России, территориальные органы ФСИН России, научные и образовательные организации ведомства. Также ограниченный доступ к РИД обусловлен и закрытостью тем исследований, выполненных исключительно в интересах определенного заказчика или в связи с исполнением Закона Российской Федерации от 21.07.1993 № 5485-1 «О государственной тайне» [3].

Общую информацию о темах и вопросах проводимых исследований, осуществляемых во ФСИН России, можно узнать из аннотированных информационных бюллетеней по основным результатам научной и научно-технической деятельности (далее также - аннотированный бюллетень) [4]. Аннотированные бюллетени формируются ежегодно на базе материалов исследований, предоставляемых организациями-исполнителями в ФКУ НИИ ФСИН России и в ФКУ НИИИТ ФСИН России. Информационные бюллетени, выпускаемые ведомственными научными организациями, содержат краткую информацию о проведенных в отчетном периоде исследованиях.

ФКУ НИИИТ ФСИН России в 2021 году подготовил аннотированный информационный бюллетень «Основные результаты научно-технической деятельности ФСИН России за 2020 год», в котором отдельно выделены следующие характеристики работы: круг заказчиков и исполнителей, описание, область применения, полученные результаты, а также информация о внедрении.

Большую часть информации, но уже об индивидуальных исследованиях, проводимых работниками, можно получить из ежегодного бюллетеня зарегистрированных тем диссертационных исследований и защищенных 
диссертаций, подготавливаемого ФКУ НИИ ФСИН России. В нем отражен перечень тем зарегистрированных диссертационных исследований и защищенных диссертаций, а также более детальные данные: Ф. И. О., должность, тема работы, объект и предмет исследования, цель работы, теоретическая и практическая значимость, научная новизна исследования, положения, выносимые на защиту.

В современных условиях во ФСИН России основной источник информации об индивидуальных и коллективных исследованиях бюллетени, но, к сожалению, это малая часть информации, которая не дает возможности сформировать целостное представление о научной работе всего ведомства.

Для развития научной организации необходима систематизация всех научных исследований. Данный вопрос рассматривался и ранее авторами в научных изданиях ФКУ НИИИТ ФСИН России, например, в работе А. Н. Дробота, Н. В. Рябовой проанализированы системы хранилищ документации федеральных органов исполнительной власти [5].

В настоящее время в ФКУ НИИИТ ФСИН России совместно с ФКУ НИИ ФСИН России проводится исследование по разработке информационной системы учета результатов деятельности научных и образовательных организаций ФСИН России.

На основании Приказа 606 [1] в целях сохранения и передачи научных знаний результаты исследований подлежат внедрению в практическую деятельность ФСИН России, а также в научную и образовательную деятельность научных и образовательных организаций ФСИН России.

Согласно статье 44 Конституции Российской Федерации интеллектуальная собственность охраняется законом [6]. Таким образом, все служебные РИД подлежат обязательному учету в первую очередь для того, чтобы официально закрепить права на них (авторское право), а затем для разработки системы хранения, управления и эффективного использования интеллектуальных ресурсов. Регистрация РИД устанавливает гражданско-правовые отношения между ее участниками, государственный учет служит решению государственно-управленческих задач.
Регулирование учета результатов НИОКР в Российской Федерации осуществляется на основании нормативных правовых актов Российской Федерации. Все научные работы, учитывая специфику учреждения, делятся на два вида: гражданского и военного назначения. В соответствии с Федеральным законом от 29.12.1994 № 77-Ф3 «Об обязательном экземпляре документов» (далее - Федеральный закон № 77-Ф3) [7] Правительством Российской Федерации принято постановление от 12.04.2013 № 327 «О единой государственной информационной системе учета научно-исследовательских, опытно-конструкторских и технологических работ гражданского назначения» (далее также - ЕГИСУ НИОКТР) [8]. Данная система призвана исключать дублирование тематик исследований.

Организацией, которая аккумулирует всю информацию в разрезе НИОКР военного, специального и двойного назначения, выступает федеральное государственное бюджетное учреждение «Федеральное агентство по правовой защите результатов интеллектуальной деятельности военного, специального и двойного назначения» (далее - ФАПРИД). Данная организация входит в структуру Федеральной службы по интеллектуальной собственности Российской Федерации. Перечень документов для учета НИОКР регламентируется требованиями приказа Минюста России № 173, Минпромнауки России № 178 от 17.07.2003 «Об утверждении форм документов, необходимых для ведения Единого реестра результатов научно-исследовательских, опытно-конструкторских и технологических работ военного, специального и двойного назначения, права на которые принадлежат Российской Федерации» [9].

Для ФАПРИД закрытое научно-производственное акционерное общество «Отделение проблем военной экономики и финансов» (город Тверь) разработало программный комплекс учета интеллектуальной собственности «Мелисса-ОИС», через который происходит заполнение сведений по НИОКР военного назначения, где предусматривается (в дополнение к другим задачам) поиск аналогов результатов интеллектуальной деятельности по различным критериям, а также поиск дублирования НИОКР. 
Bсе научные работы, имеющие характер закрытого исследования, отправляются для учета в ФАПРИД, исследования гражданского назначения - в ЕГИСУ НИОКТР.

В ФКУ НИИИТ ФСИН России большая часть работ идентифицируются как исследования гражданского назначения.

Направление документации по исследованиям является обязательным этапом, который включает в себя тот же объем работы и в первую очередь связан с осуществлением нормоконтроля отчетной научно-технической документации по НИОКР и научным (научно-техническим) результатам, проводимым в рамках этих НИОКР, а также с осуществлением соответствующих патентных исследований.

В результате проведения научно-исследовательских и опытно-конструкторских работ (далее - НИР, ОКР) создаются документы, содержащие РИД, - заключительные отчеты о НИР или ОКР, а также промежуточные отчеты.

Учитывая важность сохранения научно-технической информации о всех разрабатываемых РИД, необходимо соблюдать следующий алгоритм действий.

В соответствии с Федеральным законом № 77-ФЗ и Приказом Министерства культуры Российской Федерации от 26.12.2017 № 2227 «Об утверждении Порядка доставки, хранения, учета обязательного экземпляра печатного издания в электронной форме, мер защиты при доставке обязательного экземпляра печатного издания в электронной форме, порядка компьютерной обработки данных обязательного экземпляра печатного издания в электронной форме в целях их классификации и систематизации, а также требований к формату доставляемого файла обязательного экземпляра печатного издания в электронной форме» производители документов обязаны передавать на хранение на безвозмездной основе экземпляры печатных изданий получателям обязательных документов [10]. Институт в ходе своей прикладной научно-технической деятельности создает ряд документов, подпадающих под действие настоящих нормативных правовых актов. Обязательному учету подлежат следующие документы учреждения:

1) печатные издания (например, сборники научных работ, научные журналы);
2) печатные издания в электронной форме;

3) электронные издания (например, аудиовизуальные пособия, включающие видеоинформацию, интерактивную и иную, представленную в электронно-цифровой форме);

4) неопубликованные документы (например, отчеты о научно-исследовательских и опытно-конструкторских работах, алгоритмы и программы);

5) программы для электронных вычислительных машин и базы данных на материальных носителях.

Направление обязательных экземпляров перечисленных изданий, продукции и документов осуществляется в различные организации с учетом своей специфики.

1. Доставка обязательного экземпляра печатного издания осуществляется:

- в федеральный орган исполнительной власти в сфере печати, средств массовой информации и массовых коммуникаций в одном экземпляре в день выхода в свет первой партии тиража издания;

- в Национальное фондохранилище отечественных печатных изданий на базе Российской книжной палаты в количестве 16 обязательных экземпляров книг и брошюр, журналов и продолжающихся изданий на русском языке пляров авторефератов диссертаций и диссертаций в виде научных докладов; 10 обязательных экземпляров стандартов в день выхода в свет первой партии тиража издания**.

После проведенных процедур по отправке и регистрации в Российской книжной палате обязательного экземпляра печатного издания осуществляется статистический учет издательской продукции. Завершающим звеном является предоставление производителями документов, сведений об использовании номеров ISBN, ISSN (форма № 1-И) в Российскую книжную палату ${ }^{\star * *}$.

2. Доставка обязательного печатного экземпляра в электронной форме осуществляется:

* С указанием номера ISBN.

** Дата направления обязательных экземпляров должна соответствовать дате, отраженной в выходных данных печатного издания.

*** Российское национальное агентство ISBN функционирует в составе Российской книжной палаты. 
- в Российскую книжную палату в одном экземпляре в течение семи дней с даты выхода первого тиража издания по электронному адресу online.bookchamber.ru, на котором учреждение должно быть зарегистрировано.

- в Российскую государственную библиотеку в одном экземпляре (заверенном квалифицированной электронной подписью ФКУ НИИИТ ФСИН России) в течение семи дней с даты выхода первого тиража издания, через информационную систему приема обязательных экземпляров печатных изданий в электронной форме на сайте oek.rsl.ru, где учреждению также необходима регистрация.

В настоящее время в соответствии с распоряжением Правительства Российской Федерации от 26.01.2021 № 150-р утвержден План мероприятий («дорожная карта»), направленных на передачу функций филиала федерального государственного унитарного предприятия «Информационное телеграфное агентство России (ИТАР-ТАСС)» Российская книжная палата федеральному государственному бюджетному учреждению «Российская государственная библиотека», в котором одним из мероприятий является разработка проекта федерального закона о внесении изменений в Федеральный закон «Об обязательном экземпляре документов» в части передачи функций, возложенных в соответствии с указанным законом на федеральное унитарное предприятие «Информационное телеграфное агентство России (ИТАР-ТАСС)», федеральному государственному бюджетному учреждению «Российская государственная библиотека» [11].

3. Доставка электронных изданий осуществляется:

- в Межотраслевой научно-исследовательский институт «Интеграл» одного обязательного экземпляра программ для электронных вычислительных машин и баз данных;

- в Научно-технический центр «Информрегистр» пяти экземпляров через систему государственной регистрации информационных ресурсов «Информрегистр» посредством почтовой связи (бандеролью);

- в Президентскую библиотеку имени Б. Н. Ельцина одного обязательного экземпляра электронных изданий посредством почтовой связи (бандеролью или курьером).
4. Доставка обязательного экземпляра неопубликованных документов

Направление обязательного экземпляра неопубликованных документов в виде отчетов о научно-исследовательских и опытно-конструкторских работах, алгоритмов и программ осуществляется посредством их отправки в федеральное государственное автономное научное учреждение «Центр информационных технологий и систем органов исполнительной власти» для учета в единой государственной системе учета научно-исследовательских, опытно-конструкторских и технологических работ гражданского назначения.

В целях информационного обеспечения научной, научно-технической и инновационной деятельности Министерство науки и высшего образования Российской Федерации приказом Минобрнауки России от 25.09.2020 № 1234 «Об утверждении форм направления сведений, указанных в пункте 3 Положения о единой государственной информационной системе учета научно-исследовательских, опытно-конструкторских и технологических работ гражданского назначения, утвержденного постановлением Правительства Российской Федерации от 12 апреля 2013 г. № 327, требований к заполнению и направлению указанных форм, порядка подтверждения главными распорядителями бюджетных средств, осуществляющими финансовое обеспечение научно-исследовательских, опытно-конструкторских и технологических работ гражданского назначения и выполняющими функции заказчика таких работ, соответствия сведений об указанных работах, внесенных в единую государственную информационную систему учета научно-исследовательских, опытно-конструкторских и технологических работ гражданского назначения, условиям государственных контрактов на выполнение научно-исследовательских, опытно-конструкторских и технологических работ гражданского назначения» (далее - Приказ № 1234) [12].

В данной информационной системе отчитываются за проводимые работы те организации, которые используют средства федерального бюджета.

Объектами учета в системе ЕГИСУ НИОКТР являются: 
- сведения о начинаемых работах;

- сведения о результатах работ, предоставленных в соответствии с Федеральным законом № 77-Ф3 в форме обязательных экземпляров неоформленных документов;

- сведения о правообладателях, правах на созданные РИД, а также дальнейшее практическое применение результатов в научной деятельности.

Функции по формированию и ведению учета единой государственной информационной системы учета научно-исследовательских, опытно-конструкторских и технологических работ гражданского назначения возложено на Министерство науки и высшего образования Российской Федерации.

В данное учреждение направляются помимо самих обязательных документов (отчетов о НИОКР, описаний результатов интеллектуальной деятельности - алгоритмов и программ) и сопутствующие (вторичные) документы формы. Формы и требования по их заполнению утверждены Приказом № 1234 [12].

К вторичным документам относятся следующие:

- форма направления сведений о начинаемой научно-исследовательской, опытно-конструкторской и технологической работе (далее - НИОКТР) гражданского назначения;

- форма направления реферативно-библиографических сведений о результатах НИОКТР гражданского назначения;

- форма направления сведений о созданном результате интеллектуальной деятельности;

- форма направления сведений о состоянии правовой охраны результатов интеллектуальной деятельности;

- форма направления сведений об использовании результата интеллектуальной деятельности;

Передача обязательных экземпляров вышеуказанных документов производится в электронном виде посредством заполнения форм в онлайн-режиме через личный кабинет организации ЕГИСУ НИОКТР на сайте www.rosrid.ru.

5. Доставка обязательных экземпляров программ для электронных вычислительных машин и баз данных на материальных носителях
Направление обязательного экземпляра программ для электронных вычислительных машин и баз данных, являющихся как самостоятельным изданием, так и в составе электронного издания, осуществляется в Межотраслевой научно-исследовательский институт «Интеграл» в одном экземпляре посредством почтовой связи.

В соответствии с постановлением Правительства Российской Федерации от 30.01.2013 № 62 «О национальном фонде алгоритмов и программ для электронных вычислительных машин» [13] с 2013 года функционирует федеральная государственная информационная система по сбору, обработке и хранению алгоритмов и программ для электронных вычислительных машин, подготовительной (проектной), технической, сопроводительной и (или) методической документации к программам для электронных вычислительных машин, созданных или приобретенных с привлечением средств федерального бюджета и бюджетов государственных внебюджетных фондов, с целью их предоставления государственным органам, государственным внебюджетным фондам и органам местного самоуправления для повторного использования при внедрении информационных технологий в их деятельность - национальный фонд алгоритмов и программ для электронных вычислительных машин (далее - фонд).

Фонд содержит разделы, в которых размещаются:

- программы для электронных вычислительных машин (исходный текст, а также сама программа для электронных вычислительных машин, представленная в форме объектного кода и содержащая в том числе алгоритмы) вместе с подготовительной (проектной), технической, сопроводительной и (или) методической документацией к таким программам (далее - объект фонда), исключительные права на которые и (или) права на использование которых, включая воспроизведение, распространениеи модификацию, принадлежат Российской Федерации;

- объект фонда, исключительные права на которые и (или) права на использование которых, включая воспроизведение, распространение и модификацию, принадлежат субъекту Российской Федерации. 
В данном фонде размещаются лишь те объекты, которые являются результатами интеллектуальной деятельности, подлежащими правовой охране, то есть имеют государственную регистрацию и исключительные права, закрепленные за Российской Федерацией. Размещению в фонде не подлежат программы для ЭВМ, подготовительная (проектная), техническая, сопроводительная и (или) методическая документация к программам для электронных вычислительных машин, содержащие сведения, доступ к которым ограничен федеральными законами.

С целью сохранения научно-технической информации, результатов научных исследований, обеспечения преемственности знаний и передачи их в практическую деятельность ведомства необходимо вести учет результатов научных исследований. Единая база данных НИОКР во ФСИН России с возможностью автоматизированного учета знаний научных организаций поможет исключить негативные факторы:

- дублирование научных исследований;
- ограниченность в доступе к РИД в связи с территориально-распределенным и децентрализованным хранением научных исследований;

- отсутствие системного подхода по учету полученных научных и научно-технических результатов.

Подводя итог, авторы приходят к главному выводу: законодательное регулирование учета результатов научно-исследовательских и опытно-конструкторских работ - неотъемлемое условие развития для всего пенитенциарного ведомства. Создание собственной ведомственной автоматизированной системы учета научных и научно-технических результатов, объединение всех НИОКР в едином центре ФСИН России позволит оптимизировать планирование, учет, контроль, обеспечит больший объем внедрения научных исследований и возможность обмена опытом и знаниями в деятельности УИС. На наш взгляд, реализация данного подхода будет способствовать повышению качества научного обеспечения всей пенитенциарной системы. $\diamond$

1. О научном обеспечении деятельности уголовно-исполнительной системы : приказ ФСИН России от 02.09.2020 № 606. Доступ из СПС «КонсультантПлюс».

2. Рябова Н. В., Дробот А. Н., Корнилова Ю. А. Сохранение знаний научной организации // Вестник ФКУ НИИИТ ФСИН России (научно-практическое издание). Тверь : ФКУ НИИИТ ФСИН России, 2019. Выпуск 2. С. 195-201.

3. О государственной тайне : закон Российской Федерации от 21.07.1993 № 5485-1 (последняя редакция). Доступ из СПС «КонсультантПлюс».

4. Аннотированный информационный бюллетень // ФКУ НИИ ФСИН России : [сайт]. 31.03.2021 URL: https://nii.fsin.gov.ru/trudy-nii/sborniki/index.php (дата обращения: 17.05.2021).

5. Дробот А. Н., Рябова Н. В. Перспективы автоматизации учета научной и научно-технической продукции, созданной в пенитенциарной службе страны // Актуальные вопросы информатизации Федеральной службы исполнения наказаний на современном этапе развития уголовно-исполнительной системы : сборник материалов круглого стола (24 июня 2019 г.). Тверь : ФКУ НИИИТ ФСИН России, 2019. С. 60-66.

6. Конституция Российской Федерации : принята всенародным голосованием 12.12.1993 (с изм., одобренными в ходе общероссийского голосования 01.07.2020). Доступ из СПС «КонсультантПлюс».

7. Об обязательном экземпляре документов : федер. закон Российской Федерации от 29.12.1994 № 77-Ф3 (ред. от 08.06.2020). Доступ из СПС «КонсультантПлюс».

8. О единой государственной информационной системе учета научно-исследовательских, опытно-конструкторских и технологических работ гражданского назначения (вместе с «Положением о единой государственной информационной системе учета научно-исследовательских, опытно-конструкторских и технологических работ гражданского назначения») : пост. Правительства Российской Федерации от 12.04.2013 № 327 (ред. от 01.10.2018). Доступ из СПС «КонсультантПлюс».

9. Об утверждении форм документов, необходимых для ведения Единого реестра результатов научно-исследовательских, опытно-конструкторских и технологических работ военного, специального и двойного назначения, права на которые принадлежат Российской Федерации : приказ Минюста России № 173, Минпромнауки России № 178 от 17.07.2003. Доступ из СПС «КонсультантПлюс». 
10. Об утверждении Порядка доставки, хранения, учета обязательного экземпляра печатного издания в электронной форме, мер защиты при доставке обязательного экземпляра печатного издания в электронной форме, порядка компьютерной обработки данных обязательного экземпляра печатного издания в электронной форме в целях их классификации и систематизации, а также требований к формату доставляемого файла обязательного экземпляра печатного издания в электронной форме (не вступил в силу) : приказ Министерства культуры Российской Федерации от 26.12.2017 № 2227. Доступ из СПС «Гарант».

11. План мероприятий «дорожная карта», направленных на передачу функций филиала федерального государственного унитарного предприятия «Информационное телеграфное агентство России (ИТАР-ТАСС)» Российская книжная палата федеральному государственному бюджетному учреждению «Российская государственная библиотека», в котором одним из мероприятий является разработка проекта федерального закона о внесении изменений в Федеральный закон «Об обязательном экземпляре документов» в части передачи функций, возложенных в соответствии с указанным законом на федеральное унитарное предприятие «Информационное телеграфное агентство России (ИТАР-ТАСС)», федеральному государственному бюджетному учреждению «Российская государственная библиотека» : утв. распор. Правительства Российской Федерации от 26.01.2021 № 150-р. Доступ из СПС «КонсультантПлюс».

12. Об утверждении форм направления сведений, указанных в пункте 3 Положения о единой государственной информационной системе учета научно-исследовательских, опытно-конструкторских и технологических работ гражданского назначения, утвержденного постановлением Правительства Российской Федерации от 12 апреля 2013 г. № 327, требований к заполнению и направлению указанных форм, порядка подтверждения главными распорядителями бюджетных средств, осуществляющими финансовое обеспечение научно-исследовательских, опытно-конструкторских и технологических работ гражданского назначения и выполняющими функции заказчика таких работ, соответствия сведений об указанных работах, внесенных в единую государственную информационную систему учета научно-исследовательских, опытно-конструкторских и технологических работ гражданского назначения, условиям государственных контрактов на выполнение научно-исследовательских, опытно-конструкторских и технологических работ гражданского назначения : приказ Минобрнауки России от 25.09.2020 № 1234. Доступ из СПС «КонсультантПлюс».

13. О национальном фонде алгоритмов и программ для электронных вычислительных машин» (вместе с «Положением о национальном фонде алгоритмов и программ для электронных вычислительных машин») : пост. Правительства Российской Федерации от 30.01.2013 № 62 (с изм. и доп.) Доступ из СПС «КонсультантПлюс».

1. On the organization of educational work with personnel of the penal system : Order of the Federal Penitentiary Service of the Russian Federation of 02.09.2020 No. 606. Access from Legal Reference System «Consultant Plus».

2. Ryabova, N.V., Drobot, A.N., Kornilova, Yu. A. (2019) Preservation of the knowledge of a scientific organization // Bulletin of the Federal Governmental Institution «Scientific Research Institute of Information Technologies of the FPS of Russia» (scientific and practical publication). Tver : Federal Governmental Institution «Scientific Research Institute of Information Technologies of the FPS of Russia», 2, 195-201.

3. On state secrets : the law of the Russian Federation dated 21.07.1993 No. 5485-1 (last version). Access from Legal Reference System «Consultant Plus».

4. Annotated newsletter // Federal Governmental Institution «Research Institute of the Federal Penitentiary Service of Russia»: [site]. 31.03.2021 URL: https://nii.fsin.gov.ru/trudy-nii/sborniki/index. php [Accessed $17^{\text {th }}$ May 2021].

5. Drobot, A. N., Ryabova, N. V. (2019) Prospects for the automation of accounting of research and scientific and technical products created in the country's penitentiary service // Topical issues of informatization of the Federal Penitentiary Service at the current stage of development of the penal system : collection of materials of the round table (June 24, 2019). Tver : Federal Governmental Institution «Scientific Research Institute of Information Technologies of the FPS of Russia», pp. 60-66. 
6. Constitution of the Russian Federation : adopted by popular vote on 12.12.1993 (with amendments approved during the all-Russian vote on 01.07.2020). Access from Legal Reference System «Consultant Plus».

7. On the mandatory copy of documents: Federal Law of the Russian Federation of 29.12.1994 No. 77-FZ (as revised on 08.06.2020). Access from Legal Reference System «Consultant Plus».

8. On the unified state information system for recording research, development and technological work for civilian purposes (together with the «Regulations on the unified state information system for recording research, development and technological work for civilian purposes») : Resolution of the Government of the Russian Federation No. 327 dated 12.04.2013 (as revised on 01.10.2018). Access from Legal Reference System «Consultant Plus».

9. On the approval of the forms of documents required for maintaining the Unified Register of the results of research, development and technological work of military, special and dual-use, the rights to which belong to the Russian Federation : Order of the Ministry of Justice of Russia No. 173, Ministry of Education and Science of the Russian Federation No. 178 dated 17.07.2003. Access from Legal Reference System «Consultant Plus».

10. On approval of the Procedure for the delivery, storage, accounting of a legal copy of a printed publication in electronic form, protection measures for the delivery of a legal copy of a printed publication in electronic form, the procedure for computer processing of data in a legal copy of a printed publication in electronic form in order to classify and systematize them, as well as requirements for the format of the file to be delivered in an obligatory copy of the printed publication in electronic form (has not entered into force) : Order of the Ministry of Culture of the Russian Federation dated 26.12.2017 No. 2227. Access from Legal Reference System «Garant».

11. Action plan «road map» aimed at transferring the functions of a branch of the federal state unitary enterprise «Information Telegraph Agency of Russia (ITAR-TASS)» Russian Book Chamber to the federal state budgetary institution «Russian State Library», in which one of the activities is the development of a draft federal law on amendments to the Federal Law «On the legal copy of documents» in terms of the transfer of functions assigned in accordance with this law from the federal unitary enterprise «Information Telegraph Agency of Russia (ITAR-TASS)» to the federal state budgetary institution «Russian State Library : approved by Ordinance of the Government of the Russian Federation dated 26.01.2021 No. 150-r. Access from Legal Reference System «Consultant Plus».

12. On the approval of the forms for sending information specified in paragraph 3 of the Regulations on the unified state information system for recording scientific research, experimental design and technological work for civil purposes, approved by the Government of the Russian Federation dated April 12, 2013 No. 327, the requirements for filling out and sending the specified forms, the procedure for confirmation by the main administrators of budget funds who provide financial support for scientific research, experimental design and technological work for civil purposes and perform the functions of a customer of such work, the compliance of information on these works entered into the unified state information system for recording research, experimental design and technological work for civil purposes, the terms of state contracts for the performance of research, development and technological work for civil purposes : Order of the Ministry of Education and Science of Russia dated 25.09.2020 No. 1234. Access from Legal Reference System «Consultant Plus».

13. On the National Fund of Algorithms and Programs for Electronic Computing Machines (together with the «Regulations on the National Fund for Algorithms and Programs for Electronic Computing Machines») : Resolution of the Government of the Russian Federation No. 62 dated 30.01.2013 (as amended and supplemented) Access from Legal Reference System «Consultant Plus». 
DOI $10.51522 / 2307-0382-2021-229-6-56-61$

УДК 343.8

\section{Т. В. КИРИЛЛОВА}

главный научный сотрудник отдела психологического обеспечения профессиональной деятельности сотрудников уголовно-исполнительной системы НИЦ-2 ФКУ НИИ ФСИН России, профессор кафедры юридической психологии и педагогики Академии ФСИН России, доктор педагогических наук, профессор

Москва

\section{TATIANA V. KIRILLOVA}

Chief Researcher of the Department for Psychological Support of the Professional Activities of the Penitentiary System Officers of the Research Center-2 of the Federal Governmental Institution «Research Institute of the Federal Penitentiary Service of Russia», Professor of the Department of Legal Psychology and Pedagogy of the Academy of the FPS of Russia, Doctor of Pedagogy, Professor

Moscow

\section{Исправление осужденных путем переориентации их эмоционально-волевых качеств}

\section{Correction of convicts by reorientation of their emotional-volitional qualities}

Аннотация. В статье рассматриваются научные подходы к изучению эмоциональной и волевой сфер личности осужденных, их значение для организации исправительного воздействия, коррекционной и профилактической работы с различными категориями осужденных. Предметом статьи выступили официальные статистические данные, научная литература по рассматриваемой проблеме. Целью стало исследование эмоционально-волевых качеств осужденных. Методологическую основу исследования составили системно-структурный, формально-логический методы, общенаучные методы анализа и синтеза. В результате проведенной работы изучены понятия «эмоциональная сфера личности» и «волевая сфера личности» применительно к реалиям пенитенциарного социума. Приведены результаты исследования эмоционально-волевых качеств осужденных, обоснована классификация осужденных по их эмоционально-воле-
Abstract. The article examines scientific approaches to the study of the emotional and volitional spheres of convicts' personality, their importance for the organization of corrective impact, corrective and preventive work with various categories of convicts. The subject of the article is the official statistics, scientific literature on the problem considered. The aim was to study the emotional and volitional qualities of convicts. The methodological basis of the research was formed by the system-structural, formal-logical methods, general scientific methods of analysis and synthesis. As a result of the work carried out, the concepts of «emotional sphere of personality» and «volitional sphere of personality» were studied in relation to the realities of the penitentiary society. The results of a study of the emotional-volitional qualities of convicts are presented, the classification of convicts according to their emotional-volitional qualities is substantiated. Conclusions are made about increasing the effectiveness of corrective im- 
вым качествам. Сделаны выводы о повышении эффективности исправительного воздействия на осужденных с учетом полученных результатов пилотного исследования.

Ключевые слова: осужденные, эмоционально-волевые качества личности, диагностика, коррекция, исправительное воздействие. pact on convicts, taking into account the results of the pilot study.

Key words: convicts, emotional and volitional personality traits, diagnostics, correction, corrective impact.

13.00.01 Общая педагогика, история педагогики и образования (педагогические науки) General pedagogy, history of pedagogy and education (pedagogical sciences)

$\Pi$ енитенциарная наука и практика нуждаются в исследованиях, результаты которых смогут стать обоснованием действенных методов исправления осужденных. Для повышения эффективности исправительного воздействия на осужденных, отбывающих наказание в местах лишения свободы, для социальной и психологической работы с осужденными, организации процесса их воспитания и образования необходим «поиск и внедрение новых индивидуальных форм работы, обеспечивающих оказание адресной социальной, психологической и педагогической помощи каждому осужденному с учетом его социально-демографической, уголовно-правовой и индивидуально-психологической характеристики» [1].

Успешность организации исправительного воздействия, коррекционной и профилактической работы с различными категориями осужденных в значительной степени зависит от выявления их психологических и педагогических характеристик, в том числе изучения эмоциональной и волевой сфер личности. Теоретическое изучение этого вопроса, проведение научных исследований, анализ полученной статистической информации и практических ситуаций, несомненно, обогатит пенитенциарных психологов и педагогов новыми данными, направленными на поиск и апробацию действенных методов исправительного воздействия на осужденных.
Проведем краткий анализ понятий «эмоциональная сфера личности» и «волевая сфера личности» применительно к реалиям пенитенциарного социума.

Эмоциональные проявления, значение эмоций для самосознания, саморегуляции, поведения и мотивации поступков человека издревле являлись объектом, вызывающим интерес ученых. В психологическом словаре эмоции трактуются как «самостоятельный разряд психических состояний и процессов, которые связаны с потребностями, мотивами и инстинктами, и которые проявляются в виде переживания (удовлетворенности, неудовлетворенности, радости, печали, страха, спокойствия и т. д.) значимости воздействующих ситуаций и явлений на индивида, которые осуществляют его жизнедеятельность Эмоции сопровождают любую активность субъекта, они выполняют функцию основного и главного механизма, осуществляющего регуляцию поведения и психической активности, направленных на удовлетворение наиболее значимых для человека, потребностей» [2].

Мы разделяем точку зрения М. И. Гурьева [3], Л. В. Скрипки [4], которые считают, что мотивационная система человека неразрывно связана с его эмоциональной сферой. Эмоции могут оказывать как разрушающее, дезорганизующее воздействие на поступки человека, так и мотивирующее, способствующее организации 
процессов ресоциализации. В контексте противоправного и преступного поведения особенно важно изучение связи эмоциональных состояний с состоянием аффекта.

По мнению М. Е. Гурьева, «...изучение эмоциональных состояний имеет большое прикладное значение. Практически вся система психологической коррекции основана на работе с ситуативными особенностями индивида. Коррекция черт личности происходит на основе выработки и закрепления положительных состояний. Кроме того, в исключительных случаях, диагностика эмоциональных состояний является единственным показателем эффективности деятельности субъекта» [3].

Очевидно, что коррекция эмоциональной сферы осужденных в свете вышесказанного имеет важное значение во всем процессе исправления, а изучение эмоциональной сферы осужденных во всех ее проявлениях - важная задача пенитенциарных психологов.

Обратимся к волевой сфере личности осужденного. Диагностика и анализ волевых качеств личности весьма существенно влияют на организацию исправительного воздействия на осужденных. Волевые качества личности необходимо учитывать как системообразующие компоненты ее социальной направленности. Волевые качества могут иметь различную полярность. Так, сильная воля может быть направлена как во имя интересов общества, так и на достижение преступной цели [5].

Одними из исследователей волевой сферы личности осужденных в пенитенциарной психологии являются В. Г. Деев и М. В. Тимашев, которые предлагают в своих работах следующее определение: «Воля определяется как целенаправленное саморегулирование человеком своего поведения, выраженное в способности сознательно преодолевать препятствия и трудности при совершении действий и поступков» [6]. В структуру воли входят волевые процессы, действия, состояния и качества личности. Мы полагаем, что основное внимание пенитенциарных психологов должно быть обращено на волевые процессы и действия, так как именно с их помощью личность регулирует свою активность, свое поведение в целом. Первичная диагностика волевой сферы осужденных часто выявляет деформацию волевых действий, требующую коррекционной работы, выработку опыта проявления волевых усилий, препятствующих совершению противоправных действий, достижению асоциальных целей.

Деформация проявляется в том, что процесс преодоления трудностей и достижения цели у осужденных проходит зачастую импульсивно. А. И. Ушатиков, Б. Б. Казак подчеркивают, что «...в волевом действии у осужденных часто выпадает этап планирования, а для завершения действия им не хватает выдержки и настойчивости. В итоге трудности не преодолеваются, а положительные цели либо не достигаются, либо достигаются частично, либо замещаются легкодоступными, в том числе отрицательными» [7].

В контексте организации исправительного воздействия на осужденных мы выделяем коррекционную работу по формированию способности произвольного управления своим поведением с ресурсным использованием волевого компонента личности, целеполагания, планирования своих действий. Данная работа особенно важна на этапе постпенитенциарной адаптации к социальному окружению, так как способствует снижению рисков совершения повторных преступлений и, собственно, рецидивной преступности. Однако и на этапе отбытия наказания этот 
аспект играет значительную роль в нормализации, стабилизации оперативной обстановки в учреждениях, исполняющих наказания в виде лишения свободы, исключении или минимизации воздействия криминальной субкультуры на личность и поведение отдельных осужденных, поддающихся психологической манипуляции, давлению, влиянию, и вследствие этого совершающих преступления в местах лишения свободы.

Вопросы эмоциональной и волевой сфер личности осужденных чрезвычайно интересны для изучения, но перспективное направление развития пенитенциарной науки предлагает М. В. Чумаков, который считает, что эти сферы должны рассматриваться в своем единстве и использует термин «эмоционально-волевая сфера личности». Он указывает, что «данный термин применяется в основном в прикладных и экспериментальных исследованиях при описании регуляции конкретных видов деятельности в конкретных условиях. Вполне понятно, что регуляция действует как целостный механизм, что различные сферы личности связаны между собой. В связи с этим сохраняет актуальность вопрос о рассмотрении взаимодействия, взаимообусловленности эмоциональной и волевой регуляции, единства эмоциональной и волевой сфер личности. К рассмотрению этого вопроса можно подойти с различных сторон: со стороны участия эмоций в волевых процессах и участия волевых процессов в эмоциональной регуляции. Можно попытаться обнаружить более глубокие взаимосвязи, рассмотреть эти виды регуляции в неразрывном единстве» [8]. Такой подход позволяет значительно расширить поле научных исследований и повысить прогностичность полученных результатов.

Мы, в свою очередь, предприняли попытку систематизации осужденных с уче- том исследования их эмоционально-волевой сферы с целью выработки некоторых рекомендаций по организации исправительного воздействия в условиях пенитенциарных учреждений.

Исследование эмоциональных и волевых качеств осужденных проводилось в исправительных колониях общего и строгого режима в территориальных органах ФСИН России. Изучались эмоциональные и волевые качества до осуждения и в условиях отбывания наказания. В ходе проведенного пилотного исследования нами выявлены следующие группы осужденных мужчин с позиции проявления эмоциональных и волевых качеств:

1) осужденные, проявляющие в целом устойчивые положительные эмоциональные и волевые качества;

2) осужденные, характеризующиеся неустойчивым проявлением эмоциональных и волевых качеств;

3) осужденные, устойчиво проявляющие отрицательные эмоциональные и волевые качества. Эта группа осужденных наиболее трудно поддается исправительному воздействию.

Каждая из выделенных нами групп осужденных имеет свои особенности, которые необходимо учитывать при организации и проведении мероприятий воспитательного характера в исправительных учреждениях. В наших предыдущих публикациях на эту тему мы подробно рассматривали каждую группу осужденных и давали конкретные практические рекомендации сотрудникам по организации исправительного воздействия. В данной статье мы приведем обобщенную таблицу, в которой представлена характеристика групп осужденных в зависимости от проявления эмоционально-волевых качеств, влияющих на эффективность исправления. 


\section{Характеристика групп осужденных в зависимости от проявления их эмоционально-волевых качеств}

\begin{tabular}{|c|c|c|}
\hline $\begin{array}{c}\text { № } \\
\Pi / \boldsymbol{\Pi} \\
\end{array}$ & Группа & Эмоциональные и волевые качества \\
\hline 1 & $\begin{array}{l}\text { Осужденные, } \\
\text { проявляющие в } \\
\text { целом устойчи- } \\
\text { вые положитель- } \\
\text { ные эмоциональ- } \\
\text { ные и волевые } \\
\text { качества }\end{array}$ & $\begin{array}{l}\text { 1. Демонстрируют уравновешенное поведение, критически относятся } \\
\text { К окружающим, регулируют свою психическую деятельность } \\
\text { 2. Не отказываются в условиях отбывания наказания от работы и } \\
\text { учебы, проявляют дисциплинированность, целеустремленность, } \\
\text { оптимизм, внимательность; адекватно реагируют на меры воспита- } \\
\text { тельного воздействия } \\
\text { 3. Проявляют боязнь по отношению к лидерам групп отрицательной } \\
\text { направленности, что может способствовать нарушению режима, } \\
\text { проявлению поведения, несоответствующего нравственным и пра- } \\
\text { вовым нормам } \\
\text { 4. Осознают отрицательные качества, охотно принимают участие в } \\
\text { психокоррекционных мероприятиях }\end{array}$ \\
\hline 2 & $\begin{array}{l}\text { Осужденные, ха- } \\
\text { рактеризующие- } \\
\text { ся неустойчивым } \\
\text { проявлением } \\
\text { эмоциональных и } \\
\text { волевых качеств }\end{array}$ & $\begin{array}{l}\text { 1. Демонстрируют неустойчивое проявление таких волевых качеств, } \\
\text { как самостоятельность, принципиальность, целеустремленность. } \\
\text { Осужденные этой группы менее активны, нерешительны при выпол- } \\
\text { нении поручений, не обладают настойчивостью } \\
\text { 2. Свойственна эмоциональная несдержанность, слабая сила воли, } \\
\text { резкость, грубость в межличностном общении } \\
\text { 3. Самоутверждаются через отрицательно настроенную частью } \\
\text { осужденных, которые используют их в своих целях, демонстрируют } \\
\text { поведение, граничащее с нарушением режима } \\
\text { 4. Характеризуются повышенной эмоциональной возбудимостью, лож- } \\
\text { ным представлением о действительности } \\
\text { 5. Отрицательно реагируют на воспитательные мероприятия, у них } \\
\text { происходит искаженное восприятие получаемой от сотрудников } \\
\text { исправительного учреждения информации. Поставленных целей } \\
\text { добиваются любыми средствами } \\
\text { 6. Слабость волевых усилий проявляется в невозможности продолжи- } \\
\text { тельное время заниматься работой или учебой } \\
\text { 7. Быстро утомляются, свойственно конфликтное поведение, грубы, } \\
\text { доводят себя до аффективных состояний. Стараются выйти из-под } \\
\text { контроля сотрудников, поддерживают при возможности связи с } \\
\text { отрицательно направленными осужденными }\end{array}$ \\
\hline 3 & $\begin{array}{l}\text { Осужденные, } \\
\text { устойчиво } \\
\text { проявляющие } \\
\text { отрицательные } \\
\text { эмоциональные } \\
\text { и волевые каче- } \\
\text { ства }\end{array}$ & $\begin{array}{l}\text { 1. Характеризуются сильной волей, отсутствием чувства сострадания и } \\
\text { осознания вины, грубостью, жестокостью, принятием и реализацией } \\
\text { асоциальных решений } \\
\text { 2. Пренебрежительно относятся к труду и учебе, взаимоотношения с } \\
\text { окружающими строят с позиции физической силы } \\
\text { 3. Чаще это глубоко социально-педагогически запущенные люди, } \\
\text { имеющие устойчивую отрицательную направленность, привержен- } \\
\text { цы криминальной субкультуры } \\
\text { 4. Демонстрируют по отношению к сотрудникам показное неуважение } \\
\text { и противодействие. Могут выражать положительные эмоциональ- } \\
\text { ные и волевые качества, но эти качества носят стойкий антиобще- } \\
\text { ственный характер, деятельность направлена на удовлетворение } \\
\text { сугубо личных интересов и низменных потребностей } \\
\text { 5. Агрессивны, проявляют эмоциональную неустойчивость }\end{array}$ \\
\hline
\end{tabular}


Комплексный, объективный учет всех названных выше личностных особенностей осужденных, их диагностика и компетентный анализ позитивной динамики позволят выявить совокупность действенных методов исправительного воздействия на осужденных, организовать воспитатель- ный процесс, направленный на коррекцию эмоциональной сферы осужденных, на выработку самоконтроля поведения и деятельности личности осужденного, навыка волевых действий, способствующих правопослушному поведению и предотвращению рецидивной преступности. $\diamond$

1. Кириллова Т. В., Кузнец,ов М. И. Об организации адресной социальной помощи в учреждениях исполнения наказаний // Глобальный научный потенциал. 2019. № 4 (97). С. 22-24.

2. Психологический словарь / под ред. В. П. Зинченко, Б. Г. Мещерякова. М. : Педагогика-Пресс, 2001. С. 612.

3. Гурьев М. Е. Сущность и структура эмоциональной сферы личности // Личность, семья и общество: вопросы педагогики и психологии. 2014. № 41. С. 125-139.

4. Скрипка Л. В. Особенности изучения воли впервые осужденных к лишению свободы // Уголовно-исполнительное право. 2014. № 2 (18). С. 159-162.

5. Купцов И. И., Пивоварова Т. В. Рациональные пути исправления несовершеннолетних осужденных // Прикладная юридическая психология. 2013. № 3. С. 26-34.

6. Деев В. Г., Тимашев М. В. Методика изучения и характеристика волевых проявлений осужденных в условиях ИТУ : учебно-практическое пособие / под ред. В. И. Селиванова. Рязань, 1975. $56 \mathrm{c}$.

7. Ущатиков А. И., Казак Б. Б. Основы пенитенциарной психологии. Рязань, 2001. 536 с.

8. Чумаков М. В. Эмоционально-волевая сфера личности субъекта // Проблемы социальной психологии личности : сборник тезисов по проблемам психологии личности. Саратов : Саратовский гос. ун-т им. Н. Г. Чернышевского, 2008. 106 с.

1. Kirillova, T. V., Kuznetsov, M. I. (2019) On the organization of targeted social support in penitentiary institutions // Global Scientific Potential. 4 (97), 22-24.

2. Ed. by Zinchenko, V. P., Meshcheryakov, B. G. (2001) Psychological dictionary. Moscow : Pedagogy-Press, p. 612.

3. Guriev, M. E. (2014) Subject matter and structure of personality affection // Personality, family and society: issues of pedagogy and psychology. 41, 125-139.

4. Skripka, L. V. (2014) Peculiarities of volition study of individuals sentenced to imprisonment for the first time // Penal law. 2 (18), 159-162.

5. Kuptsov, I. I., Pivovarova, T. V. (2013) Rational ways of correcting juvenile convicts // Applied Legal Psychology. 3, 26-34.

6. Deev, V. G., Timashev, M. V., ed. by Selivanova, V. I. (1975) Methods of studying and characteristics of volitional manifestations of convicts in the conditions of correctional labor institutions: a training manual. Ryazan, $56 \mathrm{p}$.

7. Ushatikov, A. I., Kazak, B. B. (2001) Fundamentals of Penitentiary Psychology. Ryazan, 536 p.

8. Chumakov, M. V. (2008) Emotional-volitional sphere of the subject's personality // Problems of social psychology of personality : collection of theses on the problems of personality psychology. Saratov: Saratov State University, 106 p. 
DOI 10.51522/2307-0382-2021-229-6-62-71

УДК 37.013 .42

В. И. СИЛЕНКОВ

доцент кафедры гуманитарных и естественнонаучных дисциплин Университета ФСИН России, кандидат педагогических наук, доцент, полковник внутренней службы

Санкт-Петербург

VICTOR I. SILENKOV

Assistant Professor of the Department of Humanities and Natural Sciences of the University of the Federal Penitentiary Service of Russia, Candidate of Pedagogy, Associate Professor, Colonel of the Internal Service

St. Petersburg

\section{В. Б. ПЕРВОЗВАНСКИЙ}

ведущий научный сотрудник отдела по совершенствованию нормативно-правового регулирования деятельности уголовно-исполнительной системы НИЦ-1 ФКУ НИИ ФСИН России, кандидат юридических наук, доцент должность указана на момент поступления статьи в редакиию

Москва

\section{VALERY B. PERVOZVANSKY}

Leading Researcher of the Department for the Improvement of Legal Regulation of the Penal System of the Research Center-1 of the Federal Governmental Institution «Research Institute of the Federal Penitentiary Service of Russia», Candidate of Law, Major of Internal Service, Associate Professor The position is indicated as at the time the article has been received by the editor Moscow

\section{Социально-психологические факторы детерминации наркозависимого поведения несовершеннолетних осужденных и их учет в деятельности сотрудников воспитательной колонии}

Socio-psychological factors of determination of juvenile convicts' drug-addicted behavior and their consideration in the activities of the educational colony personnel

Аннотация. Статья посвящена изучению современной ситуации употребления наркоти-
Abstract. The article is devoted to the study of the current situation in the drug use by juvenile 
ческих веществ несовершеннолетними осужденными, отбывающими наказание в воспитательных колониях. Приводятся данные официальной статистики, иллюстрирующие нарастающую динамику численности лиц, осужденных за преступления, связанные с незаконным оборотом наркотиков. Отмечается ведущая роль социально-психологических факторов в становлении наркозависимого поведения несовершеннолетних преступников. Цель исследования - выявить наиболее значимые социально-психологические факторы, способствующие детерминации наркозависимого поведения, определить возможные направления работы сотрудников воспитательных колоний по предупреждению наркозависимого поведения. Методологическую основу исследования составили анкетный, статистический метод, анализ, синтез, индукция, системно-структурный, формально-логический методы. В результате проведенной работы установлено, что уровень употребления наркотических веществ среди несовершеннолетних осужденных существенно выше как официально признаваемого, так и декларируемого самими подростками. Наиболее значимым социально-психологическим фактором, приводящим к такому поведению, являются семья, ошибки в семейном воспитании, семейное неблагополучие или отсутствие воспитания. Обращается внимание, что одним из направлений работы воспитательных колоний по предупреждению наркозависимого поведения может и должна стать работа не только с воспитанниками, но и с их родителями. Предлагается усилить ответственность родителей за наркозависимое поведение детей. Реализация сделанных выводов и предложений будет способствовать стабилизации ситуации, сокращению преступности несовершеннолетних, связанной с оборотом наркотиков.

Ключевые слова: воспитательная колония, детерминанты, наркозависимое поведение, несовершеннолетние осужденные, употребление наркотических средств, ответственность, семья. convicts serving sentences in educational colonies. The data of official statistics illustrating the growing dynamics of the number of persons convicted of crimes related to drug trafficking are presented. The leading role of socio-psychological factors in the development of drug-addicted behavior of juvenile criminals is noted. The aim of the study is to identify the most significant socio-psychological factors contributing to the determination of drugaddicted behavior, to determine possible areas of work for personnel of educational colonies to prevent the drug-addicted behavior. The methodological basis of the research was formed by the questionnaire, statistical method, analysis, synthesis, induction, system-structural and formallogical methods. As a result of the work carried out, it was established that the level of drug use among convicted juveniles is significantly higher than both officially recognized and declared by the adolescents themselves. The most significant sociopsychological factor leading to such behavior is the family, mistakes in family upbringing, family problems or lack of education. Attention is drawn to the fact that one of the areas of educational colonies work in the prevention of drug addicted behavior can and should be the work not only with the inmates, but also with their parents. It is proposed to strengthen the responsibility of parents for drug addicted behavior of children. Implementation of the conclusions and proposals made will help stabilize the situation and reduce juvenile delinquency related to drug trafficking.

Key words: educational colony, determinants, drug addicted behavior, juvenile convicts, drug use, responsibility, family.
19.00.06 Юридическая психология (психологические науки) Legal psychology (psychological sciences)

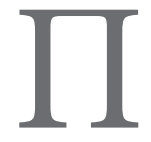

роблема предупреждения немедицинского употребления наркотических средств или психотропных веществ, несмотря на предпринима- емые государством усилия по борьбе с распространением этого явления, не теряет своей актуальности, остается важной как для общества в целом, так и для мест 
лишения свободы, в том числе применительно к лицам, отбывающим наказание в воспитательных колониях. В Стратегии национальной безопасности Российской Федерации одним из источников угроз национальной безопасности названа наркомания, которая представляет серьезную опасность для государства, экономики страны, здоровья населения [1].

Последствия употребления наркотических средств или психотропных веществ распространяются на различные сферы человеческого бытия: от нарушения физиологических функций организма, ведущих к причинению вреда здоровью, возникновению личностных и межличностных психологических проблем, до социальных явлений - деградации личности, ее отчуждения от важнейших институтов общества и последующей криминализации. Без предупреждения этого явления невозможно нормальное функционирование общества, в том числе решение таких стратегических задач развития государства, как обеспечение устойчивого естественного прироста населения, повышение продолжительности жизни, увеличение доли граждан, ведущих здоровый образ жизни, и других задач, определенных Указом Президента Российской Федерации от 07.05.2018 № 204 «О национальных целях и стратегических задачах развития Российской Федерации на период до 2024 года» [2]. Если при этом учитывать такие факторы, как не вполне устойчивое состояние здоровья нации, отрицательный естественный прирост населения страны, то становится очевидным, каково значение отмеченных составляющих ее благополучия и роли в нем подрастающего поколения.

В настоящее время одной из тенденций, наблюдаемых в исправительных колониях уголовно-исполнительной системы Российской Федерации (далее также - уго- ловно-исполнительная система), является рост количества лиц, осужденных за преступления, связанные с незаконным оборотом наркотических средств или психотропных веществ. Этот вид преступлений в количественном отношении обогнал даже традиционно высокий уровень имущественных преступлений, занимающий лидирующие позиции в общей структуре преступности. Так, по данным ФСИН России, доля лиц, отбывающих наказания за преступления имущественной направленности (кражи, грабежи, разбои) в 2020 году, составила 18,9 \% (89 882 человека), в то время как доля лиц, отбывающих наказания за преступления, связанные с наркотиками, - 22,9 \% (108943 человека) [3].

Характерно, что значительная часть осужденных, привлекаемых к ответственности по статьям 228, 229, 230, 234 Уголовного кодекса Российской Федерации, - это люди молодежного возраста. Нередко они не только склонны к употреблению наркотических средств или психотропных веществ, но и отличаются устойчивым наркозависимым поведением, сформировавшимся еще в подростковом и юношеском возрасте.

Статистическая информация на официальном сайте ФСИН России не содержит данных о несовершеннолетних, осужденных по этим статьям, ввиду их небольшого удельного веса. Хотя это вовсе не означает, что несовершеннолетние не совершают подобных деяний и не вовлечены в немедицинское употребление наркотических средств или психотропных веществ или не отличаются наркозависимым поведением.

В целях изучения распространения наркозависимого поведения в среде несовершеннолетних осужденных, социально-психологических факторов его детерминации и разработки предложений по их учету в воспитательной работе для преду- 
преждения такого поведения в 2020 году нами было проведено изучение несовершеннолетних осужденных, содержащихся в одной из воспитательных колоний. Заметим, что в последние годы количество воспитательных колоний, как и среднесписочная численность содержащихся в них, неуклонно снижается. Поэтому в анкетном опросе приняли участие 45 респондентов, обучающихся в общеобразовательной школе и профессиональном училище колонии, что составило более 80 \% списочного состава.

Как показало пилотажное исследование, употребление наркотических средств или психотропных веществ достаточно широко распространено в молодежной среде. Около трети респондентов в той или иной степени знакомы с наркотиками. На регулярное или частое их употребление до попадания в места лишения свободы указали 8 \% опрошенных, почти каждый четвертый воспитанник (24 \%) из числа принявших участие в анкетировании указал, что хотя бы один раз или более пробовал различные наркотические средства или психотропные вещества, тогда как более двух третей респондентов (68 \%) заявили, что никогда не пробовали наркотики. В данном случае важно учитывать, на какой из трех стадий приобщения к наркотикам находится несовершеннолетний осужденный:

- случайное эпизодическое употребление;

- злоупотребление различными веществами, изменяющими психическое состояние;

- наркомания с явлениями психофизической зависимости.

В складывающейся ситуации последняя из приведенных, кажущаяся весьма значительной цифра представляется весьма сомнительной ввиду стремления респондентов избежать ответственности и боязни быть поставленными на профилактический учет. Защитная реакция явно ослабевает, когда речь заходит о других несовершеннолетних. На этот раз более чем две трети (69 \%) представителей данной группы в ответах на контрольные вопросы анкеты отмечают, что в их ближайшем окружении есть лица, употребляющие наркотические средства или психотропные вещества, либо им приходилось видеть, как их употребляли другие (46 \%), либо при желании они могли бы их достать (27 \%). Исходя из этого, с большой долей вероятности можно предположить, что многим несовершеннолетним осужденным, оказавшимся в референтной для них группе, служащей неким стандартом, будет сложно отказаться от сложившихся норм и правил поведения в их ближайшем окружении. Поэтому количество случаев употребления несовершеннолетними осужденными наркотических средств или психотропных веществ реально будет намного больше заявленного ими в ходе анкетирования.

Заметим, что незначительный объем выборки опрошенных несовершеннолетних осужденных вовсе не означает, что полученные результаты не отражают реальной ситуации изучаемого явления. Наличие большего количества участников выборки будет гарантией репрезентативности в том случае, когда есть вероятность того, что в генеральную совокупность могут не войти типичные представители исследуемого явления и будут опрошены не те участники (в нашем случае учащиеся гимназии или лицея). В проведенном исследовании репрезентативность выборки обеспечивается способом отбора и качественными характеристиками участников опроса, которые представляют собой уменьшенный срез генеральной совокуп- 
ности несовершеннолетних осужденных. Bсе это позволяет с большой долей вероятности экстраполировать выявленную тенденцию на криминогенную среду несовершеннолетних в целом, поскольку они отражают типичную ситуацию в соответствующей группе несовершеннолетних, иными словами - гипотетически предположить, что реальная ситуация с распространенностью употребления наркотических средств и психотропных веществ среди несовершеннолетних осужденных намного тревожнее декларируемой самими подростками.

Очевидно, что реализация государственной антинаркотической политики и основных задач Стратегии государственной антинаркотической политики Российской Федерации на период до 2030 года [4] не может быть достигнута только констатацией существующей проблемы или ее мониторингом. Любая деятельность по предупреждению употребления наркотических средств или психотропных веществ, определяющая направления, формы и методы эффективной профилактической деятельности, должна базироваться на поиске механизмов причинно-следственного комплекса, детерминирующего наркозависимое поведение. Знание таких механизмов позволяет сформулировать направления внутреннего и внешнего воздействия на личность, соответствующие генезису ее наркотической вовлеченности, разработать организационные, воспитательные и иные решения, реализация которых позволит предотвратить или хотя бы ограничить распространение этого явления, что, разумеется, может быть подтверждено более масштабным исследованием.

При рассмотрении истоков возникновения наркозависимого поведения многие авторы, обращаясь к категории «причина», пытаются установить причин- но-следственные связи его обусловленности. С нашей точки зрения, использование приема установления причинно-следственных связей при рассмотрении данного явления необходимо, но недостаточно, и более того - небезупречно, поскольку не отражает всего комплекса факторов и обстоятельств, раскрывающих его происхождение. Поэтому для всестороннего и системного раскрытия генезиса наркотизации личности, особенно несовершеннолетних, вскрытия всего комплекса возможных факторов, обстоятельств, процессов, раскрывающих и объясняющих его возникновение, правильнее, логичнее и целесообразнее использовать подход, в основе которого лежит более широкое понятие - «детерминация».

В переводе с латинского determination означает «определять, обусловливать». Детерминация - это процесс обусловливания, определения некоего явления на основе объективных закономерных взаимосвязей, взаимообусловленности специфических элементов, вещей, процессов окружающего мира. При этом детерминация наркозависимого поведения предполагает взаимодействие всех видов связей и функциональной, и статистической, и временной, и всякой другой, и, разумеется, причинно-следственной.

Говоря о наркозависимом поведении несовершеннолетних осужденных и его детерминации, важно иметь в виду, что такого поведения в его привычном понимании в условиях воспитательной колонии быть не должно в принципе. С одной стороны, в настоящее время уголовно-правовая политика применительно к несовершеннолетним приобрела четко выраженный гуманистический характер, получивший отражение в расширении применения наказаний и иных мер, не связанных с изоляцией осужденного от общества, де- 
криминализации некоторых составов преступлений. Все это привело к резкому снижению численности несовершеннолетних осужденных в воспитательных колониях и, как следствие, к увеличению плотности режима и усилению, повышению уровня контроля за поведением осужденных. С другой стороны, с момента задержания, ареста и суда до поступления несовершеннолетних в воспитательную колонию нередко проходит достаточно много времени и зависимое поведение, связанное с употреблением наркотических веществ, если оно и имело место, с большей вероятностью может быть нивелировано для определенной части зависимых путем применения в комплексе лечебно-медикаментозных, психотерапевтических, психокоррекционных и иных мер воздействия.

Все это говорит о том, что воспитательная колония потенциально обладает возможностями по предупреждению наркозависимого поведения, под которыми следует понимать широкий спектр воспитательных, социально-педагогических, психолого-коррекционных мероприятий, способствующих формированию у несовершеннолетних осужденных устойчивых взглядов, установок, тормозящих влечение к наркотическим средствам или психотропным веществам и препятствующих их употреблению после освобождения из воспитательной колонии. Эти возможности могут быть реализованы при глубоком знании и понимании персоналом учреждения социально-психологических детерминант, формирующих такое поведение, их учете в своей деятельности.

Комплекс факторов и обстоятельств, детерминирующих наркозависимое поведение несовершеннолетних, достаточно широк. В их числе А. Н. Куфтерин, С. В. Булатецкий и А. А. Рудавин [5] называют правовые, экономические, организа- ционно-управленческие, биологические, медицинские, физиологические факторы. В исследованиях М. П. Рябова [6] и А. А. Ярышевой [7] указываются социальные, педагогические, психологические и другие факторы, которые не только тесно связаны друг с другом, но в комплексе могут провоцировать и усиливать такое поведение. В последнее время стали появляться работы, в которых обосновывается генетическая детерминированность развития зависимости от любых видов психоактивных веществ [8]. Предпринимаются даже попытки выделить специальные гены, выступающие маркером наследственной предрасположенности к зависимости от опиатов как разновидностей наркотических средств [9].

Надо признать, что практические работники исправительных учреждений не обладают специальным инструментарием и соответствующими познаниями, позволяющими выделять генетические факторы. Впрочем, как представляется, в этом и нет особой необходимости. Возможно, это вопрос будущего. Сегодня же, прилагая усилия к исправлению личности, воспитательный состав колоний исходит из имеющегося уровня социальной организации воспитанников, использует средства, формы, методы и приемы воспитательной работы, соответствующие сложившемуся уровню социального развития исправительной системы, прежде всего психолого-педагогические, которых вполне хватает для выявления детерминантов такого поведения.

Следует учитывать, что детерминация наркозависимого поведения несовершеннолетних определяется совокупностью различных факторов, которые действуют на разных уровнях, в разных средах и разных условиях. В свою очередь, с точки зрения формирования стратегии предупреж- 
дения наркотизма и понимания его сущности особое место принадлежит группе социально-психологических предпосылок формирования такого поведения, в числе которых следует особо выделить семейный фактор детерминации и предпосылки, имеющие психологическую природу.

Представляется, что истоки наркотизма находятся прежде всего в семье, а также в психологических и социально-психологических особенностях личности, которые в большей мере формируются и контролируются именно семьей. Личность, имеющая антинаркотические установки, сформированные в семье, ощущающая себя ее частью, разделяющая ответственность за себя и своих близких, находящаяся под ее контролем, в меньшей мере подвержена влиянию среды, нежели та, которая не имеет такой опоры.

Опыт изучения лиц, склонных к употреблению наркотических средств или психотропных веществ, отбывающих наказания в воспитательных колониях, показывает, что истоки аддиктивного (деструктивного) поведения связаны с ошибками или отсутствием семейного воспитания. В их числе особое место занимает материнская депривация (лишение любви, заботы, внимания), которая ведет к формированию различных нарушений в соматической сфере, интеллекте и поведении. Нежеланный ребенок, загруженность родителей работой, ориентация на решение личных проблем, неспособность или нежелание матери удовлетворить базовые потребности ребенка приводят к возникновению психологического дефицита, который становится причиной определенной модели поведения, в том числе наркозависимого. Предупреждение этого явления - сложная многоаспектная проблема государственного, межведомственного уровня, как и проблема предупреждения наркотизма в целом. Она охватывает различные направления деятельности, предусматривающие защиту материнства, детства, семьи. На это направлен целый пакет документов стратегического значения, среди которых Стратегия государственной национальной политики Российской Федерации на период до 2025 года, Концепция государственной семейной политики в Российской федерации на период до 2025 года, Основы государственной культурной политики, Стратегия развития воспитания в Российской Федерации на период до 2025 года, Стратегия национальной безопасности Российской Федерации и другие. Непосредственно в рамках уголовно-исполнительной системы важное значение имеют задачи, поставленные Концепцией развития уголовно-исполнительной системы Российской Федерации на период до 2030 года [10].

Решающий «вклад» в наркотизацию личности подростка вносит семейное неблагополучие. Семья является микромоделью общества, она вырабатывает систему социальных установок в формировании жизненных целей, в реализации потребностей, определяет модель будущего поведения. В семье происходит приобретение социального опыта, которое может осуществляться как непосредственно путем прямых целенаправленных воспитательных воздействий по внедрению в сознание определенных норм и правил, так и опосредствовано - благодаря действию осознанного и неосознанного подражания родителям. Специфика семейного неблагополучия может иметь различные основания. В их числе неадекватные стили и тактики воспитания (как правило, по типу неприятия детей, жестко-авторитарного или увещевательного стиля воспитания), жестокое обращение с детьми, особенности личности родителей (в том числе с 
патологическими чертами личности). Все это ведет к дисгармоническим взаимоотношениям в семье, которые выступают источником нарушения поведения детей. В таких семьях создается неблагоприятный фон для их эмоционального развития. Ребенок постоянно ощущает беспокойство, неуверенность, тревожность, что может стать причиной психосоматического заболевания невротического или патохарактерологического порядка, обращения к наркотикам как к средству компенсации.

Подростки, отторгнутые семьей, не находящие в ней своего места, реализуют себя в общении с себе подобными. Ориентация на общение с равными несет в себе доступную форму социализации, самоутверждения, эмоционального удовлетворения, психофизической защищенности. Боязнь быть отвергнутым группой заставляет пересматривать взгляды и ценности, порождает различные формы конформизма, формирует готовность слепо следовать за лидером даже на преступление. При этом подросток психологически зависит и подражает группе, стремится показать себя сторонником общих наркотических норм, оправдывает свое отклоняющееся поведение. Ради того, чтобы быть принятым в группу, он готов пожертвовать многими интересами, ценностями, здоровьем, своей личной идентичностью. Бесконтрольное, безнадзорное общение в молодежных и подростковых группах асоциальной направленности может рассматриваться в качестве одного из ведущих социально-психологических факторов в формировании аддиктивного поведения.

Именно поэтому в воспитательных колониях наряду с педагогической работой по формированию антинаркотических установок непосредственно с личностью несовершеннолетнего осужденного необходимо пристальное внимание уделять и работе с его семьей, формированию ее ответственности за воспитание детей, необходимости постоянного контроля за времяпрепровождением и кругом общения ребенка.

Прилагая усилия к исправлению личности, важно помнить, что по отбытии установленного приговором суда срока наказания несовершеннолетний вновь вернется в семейную среду, то есть к тем истокам, которые нередко, по сути, и являлись фактором его противоправного, в том числе и наркозависимого поведения.

В части 2 статьи 38 Конституции Российской Федерации установлено, что забота о детях, их воспитание - равное право и обязанность родителей. В соответствии со статьей 63 Семейного кодекса Российской Федерации родители несут ответственность за воспитание и развитие своих детей, обязаны заботиться об их здоровье, физическом, психическом, духовном и нравственном развитии. Очевидно, если несовершеннолетний употребляет наркотики, это значит, что родительские обязанности либо не выполнены вовсе, либо выполнены далеко не в полном объеме. В этой связи можно предложить наряду с известными видами ответственности вменить родителям, несовершеннолетние дети которых отбывают наказание в воспитательных колониях, обязанность посещения воспитательных мероприятий, организованных специально для такой категории граждан.

В числе возможных предложений по работе с семьей воспитанника может быть проведение воспитательной работы с родителями как по месту жительства силами органов системы профилактики правонарушений и преступлений, так и во время посещений ими своих детей в воспитательной колонии. Наряду с традиционным информированием родителей 
об ответственности за выполнение своих обязанностей, о формах, методах, приемах воспитания детей в семье это может быть организация совместной деятельности в рамках воспитательных мероприятий, проводимых в колонии, участие в тренингах по формированию навыков коммуникации семейно-родительских отношений, устойчивости к неблагоприятному влиянию окружающих, активизации личностных ресурсов родителей и других мер, требующих последующей проработки, изучения и обоснования.
Здесь весьма важна роль воспитательского корпуса колонии, институтов гражданского общества в проведении серьезной целенаправленной работы по созданию условий для осуществления общественного контроля за деятельностью исправительных учреждений, включающего проверку исполнения методических и иных рекомендаций, соблюдения прав осужденных и их законных интересов, оказанию адресной помощи родителям несовершеннолетних осужденных на пути возвращения детей в общество, семью. $\diamond$

1. О Стратегии национальной безопасности Российской Федерации : Указ Президента Рос. Федерации от 31.12.2015 № 683 // СЗ РФ. 04.01.2016. № 1 (часть II), ст. 212.

2. О национальных целях и стратегических задачах развития Российской Федерации на период до 2024 года : Указ Президента Рос. Федерации от 07.05.2018 № 204 (ред. от 19.07.2018) // СЗ РФ. 14.05.2018. № 20, ст. 2817.

3. Характеристика лиц, содержащихся в исправительных колониях для взрослых // ФСИН России : [сайт]. URL: https://fsin.gov.ru/structure/inspector/iao/statistika/Xar-ka\%20lic\%20sodergahixsya\%20v\%20IK/ (дата обращения: 12.03.2021).

4. Об утверждении Стратегии государственной антинаркотической политики Российской Федерации на период до 2030 года : Указ Президента Рос. Федерации от 23.11.2020 № 733 // С3 РФ. 30.11.2020. № 48, ст. 7710.

5. Куфтерин А. Н., Булатеикий С. В., Рудавин А. А. Детерминанты наркомании несовершеннолетних // Совершенствование организации противодействия незаконному обороту наркотических средств и психотропных веществ в современных условиях : материалы круглого стола. Рязань: Рязанский филиал Московского университета МВД России имени В. Я. Кикотя, 2017. С. $77-88$.

6. Рябов М. П. Теоретический анализ детерминации наркотизации подростков // Вестник Ярославского государственного университета им. П. Г. Демидова. Серия «Гуманитарные науки». 2012. № 3. С. 155-157.

7. Ярышева А. А. Межличностные отношения как социально-психологическая детерминанта наркозависимого поведения у подростков // Мир науки, культуры, образования. 2010. № 4-2. C. 221-223.

8. Цыганков Б. Д., Шамов С. А., Земсков М. Н. Подходы к лечению абстинентного, постабстинентного состояния наркотических больных // Российский медицинский журнал. 2013. № 4. C. 33-35.

9. Кибитов А. О., Воскобоева Е. Ю., Чупрова Н. А. Сравнительный молекулярно-генетический анализ наследственной отягощенности по алкоголизму у больных героиновой наркоманией и алкоголизмом: полиморфизм HUMTH01-VNTR гена тирозингидроксилазы (TH) // Наркология. 2006. Т. 8, № 12. С. 81-91.

10. Концепция развития уголовно-исполнительной системы Российской Федерации на период до 2030 года : утв. распор. Правительства Рос. Федерации от 29.04.2021 № 1138-р. Доступ из СПС «КонсультантПлюс». 
1. On the National Security Strategy of the Russian Federation : Decree of the President of the Russian Federation of 31.12.2015 No. 683 // Collection of Laws of the RF. 04.01.2016. No. 1 (part II), Art. 212.

2. On national goals and strategic objectives of the development of the Russian Federation for the period until 2024 : Decree of the President of the Russian Federation of 07.05.2018 No. 204 (as amended on 19.07.2018) // Collection of Laws of the RF. 14.05.2018. No. 20, Art. 2817.

3. Characteristics of persons held in educational colonies for adults // FPS of Russia : [site]. URL: https://fsin.gov.ru/structure/inspector/iao/statistika/Xar-ka\%20lic\%20sodergahixsya\%20v\%20IK/ [Accessed 12th March 2021].

4. On the Strategy of the State Anti-Drug Policy of the Russian Federation for the period until 2030 : Decree of the President of the Russian Federation of 23.11.2020 No. 733 // Collection of Laws of the RF. 30.11.2020. No. 48, Art. 7710.

5. Kufterin, A. N., Bulatetskiy, S. V., Rudavin, A. A. (2017) Determinants of drug addiction of juveniles // Improving the organization of counteraction to illegal circulation of narcotic drugs and psychotropic substances in modern conditions : materials of the round table. Ryazan : Ryazan branch of the V. Ya. Kikot Moscow University of the Ministry of Internal Affairs of Russia, pp. 77-88.

6. Ryabov, M. P. (2012) The theoretical analysis of the determination of the teenage narcotization factors // Bulletin of the P. G. Demidov Yaroslavl State University. Series «Humanities». 3, 155-157.

7. Yarysheva, A. A. (2010) Interpersonal relations as socially psychological determinant of addiction behaviour at teenagers // The world of science, culture and education. 4-2, 221-223.

8. Tsygankov, B. D., Shamov, S. A., Zemskov, M. N. (2013) The approaches to treatment of withdrawal and post-withdrawal condition in narcologic patients // Russian medical journal. 4, 33-35.

9. Kibitov, A. O., Voskoboeva, E. Yu., Chuprova, N. A. (2006) Comparative molecular genetics analysis of a family history of alcoholism in alcohol and heroin dependent patients: humth01-vntr polymorphism in tyrosine hydroxylase gene // Narcology. Vol. 8, 12, 81-91.

10. The concept of development of the penal system of the Russian Federation until 2030 : approved by Ordinance of the Government of the Russian Federation of 29.04.2021 No. 1138-r. Access from Legal Reference System «Consultant Plus». 
DOI 10.51522/2307-0382-2021-229-6-72-78

УДК 658.72

\section{А. М. ЧЕРНЯЕВ}

старший преподаватель кафедры гуманитарных и социально-экономических дисциплин ВЮИ ФСИН России, майор внутренней службы

Владимир

\section{ALEXEY M. CHERNYAEV}

Senior Lecturer of the Department of Humanitarian and Socio-Economic Disciplines, VLI of the FPS of Russia, Major of the Internal Service

Vladimir

\section{Участие исправительных учреждений в закупках, проводимых конкурентными способами, как инструмент поиска заказов для привлечения осужденных к труду}

\section{Participation of correctional institutions in competitive procurement as a tool for finding orders for attracting convicts to work}

Аннотация. В статье рассмотрены вопросы применения норм действующего законодательства Российской Федерации о закупках в сфере участия исправительных учреждений в конкурентных способах определения поставщика. Предметом статьи выступили положения отечественного законодательства, научная литература, касающаяся вопросов исследования, а также данные статистики. Цель настоящего исследования - обозначить проблемные аспекты деятельности пенитенциарных учреждений, обусловливающие степень возможности и эффективности участия в закупках, а также обосновать неоднозначный характер предоставляемых преимуществ. Методологическую основу исследования составили анализ, индукция, системно-структурный, формально-логический и статистический методы. В результате проведенной работы изучен порядок участия исправи-
Abstract. The article analyzes the application of the current norms of the Russian Federation's legislation on procurement in the sphere of participation of correctional institutions in competitive methods of determining the supplier. The article focuses on the provisions of domestic legislation, scientific literature related to research issues, as well as statistical data. The purpose of this study is to identify the problematic aspects of the penitentiary institutions' activities that determine the level of possibility and effectiveness of participation in procurement, as well as to justify the ambiguous nature of the benefits provided. The methodological basis of the research was formed by the analysis, induction, system-structural, formal-logical and statistical methods. As a result of the work carried out, the procedure for the participation of correctional institutions in competitive methods of determining suppliers was studied, the effectiveness 
тельных учреждений в конкурентных способах определения поставщиков, проанализирована эффективность данного вида деятельности. Установлено, что потенциал механизма поиска заказов путем участия в конкурентных процедурах на практике реализуется не в полной мере. Сделанные выводы и предложенные решения могут стать основой для внесения изменений и дополнений в нормы действующего законодательства с целью более широкого участия исправительных учреждений как поставщиков продукции в закупках, проводимых конкурентными способами.

Ключевые слова: уголовно-исполнительная система, труд осужденных, заказ, закупки, конкурентные способы определения поставщика. of this type of activity was analyzed. It has been established that the potential of the mechanism of searching for orders through participation in competitive procedures is not fully implemented in practice. The conclusions drawn and the proposed solutions can become the basis for making changes and additions to the norms of the current legislation with the aim of broader participation of correctional institutions as suppliers of products in procurement conducted by competitive methods.

Key words: penitentiary system, labor of convicts, ordering, procurement, competitive methods of determining a supplier.

08.00.05 Экономика и управление народным хозяйством (экономические науки) Economics and management of the national economy (economic sciences)

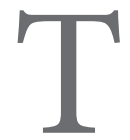

руд является важнейшим средством ресоциализации граждан, совершивших преступления. «Каждый осужденный к лишению свободы обязан трудиться в местах и на работах, определяемых администрацией исправительных учреждений. Администрация исправительных учреждений обязана привлекать осужденных к труду с учетом их пола, возраста, трудоспособности, состояния здоровья и, по возможности, специальности, а также исходя из наличия рабочих мест» [1].

Труд граждан, отбывающих наказание в виде лишения свободы, организован в центрах трудовой адаптации осужденных и производственных (трудовых) мастерских исправительных учреждений, на федеральных государственных унитарных предприятиях уголовно-исполнительной системы (далее - ФГУП УИС), а также на работах по хозяйственному обслуживанию учреждений, исполняющих наказания, и следственных изоляторов. Действующим законодательством установлена возможность осуществления тру- довой деятельности осужденных во взаимодействии подразделений ФСИН России с коммерческими организациями любых организационно-правовых форм в производственных цехах и на участках, находящихся непосредственно на территориях учреждений уголовно-исполнительной системы Российской Федерации (далее также - уголовно-исполнительная система, УИС) или за их пределами [2].

При этом если организация труда осужденных на объектах ФГУП УИС и сторонних организаций - это предоставление рабочей силы как на территориях исправительного учреждения, так и вне их, то труд в центрах трудовой адаптации осужденных связан с постоянной работой сотрудников производственных служб исправительных учреждений по поиску заказов для загрузки собственных производственных мощностей.

В статье 18 Закона Российской Федерации от 21.07.1993 № 5473-I «Об учреждениях и органах, исполняющих уголовные наказания в виде лишения свободы» содержится следующая характеристика про- 
изводственной функции УИС: «Деятельность центров трудовой адаптации осужденных и производственных (трудовых) мастерских представляет собой инициативную самостоятельную производственную деятельность (собственную производственную деятельность) учреждений, исполняющих наказания, осуществляемую на свой риск и под установленную настоящим Законом ответственность в целях исполнения требований уголовно-исполнительного законодательства Российской Федерации об обязательном привлечении осужденных к труду» [2].

Положения данной нормы закона подчеркивают самостоятельность исправительных учреждений в выборе средств и методов ведения производственной деятельности при условии строгого соответствия требованиям действующего законодательства.

В настоящее время немногим более половины осужденных, подлежащих обязательному привлечению к труду, имеют возможность трудиться и погашать из полученной заработной платы вред, причиненный потерпевшим в результате совершения преступлений. Невозможно игнорировать требования законодательства об оплате труда, в связи с чем увеличение количества работающих осужденных неизбежно повлечет рост фонда оплаты труда, формирующегося за счет средств, полученных от реализации произведенной продукции. Таким образом, постоянное повышение объема продаж выпущенных товаров позволит привлечь к труду большее количество осужденных, обеспечив при этом как минимум сохранение уровня получаемой ими заработной платы.

В этих условиях вопрос поиска заказов для загрузки имеющихся свободных производственных мощностей и дополнитель- ного обеспечения осужденных работой приобретает особую актуальность.

Возлагая на исправительные учреждения полную ответственность за эффективность работы по привлечению осужденных к труду, законодательство Российской Федерации с учетом социальной и экономической значимости данного вида деятельности предоставляет уголовно-исполнительной системе ряд преимуществ в конкурентной борьбе за заказчика. Вопросы их практической реализации, а также возникающие при этом трудности будут рассмотрены ниже.

Законодатель в положениях Федерального закона от 05.04.2013 № 44-Ф3 «О контрактной системе в сфере закупок товаров, работ, услуг для обеспечения государственных и муниципальных нужд» (далее - Федеральный закон № 44-Ф3) обозначил необходимость стимулирования государственных и муниципальных заказчиков к приобретению товаров, изготовленных в исправительных учреждениях с использованием труда осужденных [3]. Во-первых, в соответствии с пунктом 11 части 1 статьи 93 Федерального закона № 44-Ф3 учреждениям и (или) предприятиям уголовно-исполнительной системы предоставлено уникальное право закупки таких товаров, если они включены в перечень товаров (работ, услуг), утвержденный постановлением Правительства Российской Федерации от 26.12.2013 № 1292 «Об утверждении перечня товаров (работ, услуг), производимых (выполняемых, оказываемых) учреждениями и предприятиями уголовно-исполнительной системы, закупка которых может осуществляться заказчиком у единственного поставщика (подрядчика, исполнителя)» (далее - постановление № 1292) [4]. Во-вторых, положениями части 2 статьи 28 Федерального закона № 44-Ф3 установлена обязанность 
заказчика при определении поставщиков конкурентными способами предоставлять учреждениям уголовно-исполнительной системы преференции в части предлагаемой ими цены контракта в объеме до $15 \%$ в соответствии с постановлением Правительства Российской Федерации от 14.07.2014 № 649 «О порядке предоставления учреждениям и предприятиям уголовно-исполнительной системы преимуществ в отношении предлагаемых ими цены контракта, суммы цен единиц товара, работы, услуги» (далее - постановление № 649) [5].

Нормы Федерального закона № 44-Ф3, предусматривающие ряд преимуществ, предоставляемых учреждениям уголовно-исполнительной системы при участии в закупках, имеют как однозначно положительный, так и спорный эффект.

К числу первых норм можно отнести освобождение от уплаты обеспечения заявки на участие, исполнения контракта и гарантийных обязательств в соответствии с частью 6 статьи 44 и пунктом 1 части 8 статьи 96 Федерального закона № 44-Ф3.

К числу вторых относится предоставление преимуществ учреждениям уголовно-исполнительной системы в отношении предложенной ими цены контракта. Несмотря на юридическое закрепление такого механизма, практическое его применение вызывает критику исследователей.

В частности, В. И. Антонов указывает, что норма о предоставлении преимуществ учреждениям УИС не применяется в случаях, когда заказчик в составе одного лота объединяет товары как входящие в перечень товаров, утвержденный постановлением № 649, так и не включенные в данный перечень [6].

А. Н. Иванова и К. В. Шевченко отмечают, что заказчики не устанавливают в документации об осуществлении закупки преимущества учреждениям и предприя- тиям УИС в отношении предлагаемой ими цены контракта, если в спецификацию к проекту контракта входят одновременно и товары, в отношении которых постановлением № 649 предусмотрено предоставление преференций, и товары, находящиеся за рамками указанного перечня [7].

Отдельное внимание в исследовании В. И. Антонова уделяется непосредственно содержательному наполнению перечня, утвержденного постановлением № 649 . В частности, указывается, что перечень товаров, при закупке которых заказчики обязаны предоставлять преимущества учреждениям УИС, содержит незначительное количество позиций. В качестве решения данного вопроса предлагается расширение перечня либо замена его позиций на те, деятельность по которым в настоящее время действительно ведется учреждениями УИС [8].

Отметим, что сравнительный анализ перечней товаров, работ и услуг, утвержденных постановлением № 649 и постановлением № 1292, показывает отсутствие позиций, повторяющихся в обоих документах. Таким образом, законодатель отделил категории товаров, которые могут быть закуплены у учреждений УИС как у единственного поставщика, от товаров, закупка которых проводится конкурентным способом с обязательным предоставлением преимуществ в отношении цены контракта, предложенной исправительным учреждением. При этом в перечень, утвержденный постановлением № 1292, входит значительная часть номенклатуры товаров, производимых учреждениями и предприятиями УИС. В этих условиях расширение перечня, утвержденного постановлением № 649, представляется эффективным, только если будет осуществляться не за счет позиций, включенных в перечень, утвержденный постановлением 1292 , 
и, таким образом, не повлечет сужения права заказчика на заключение контракта с учреждением УИС как с единственным поставщиком.

Отдельной проблемой в теме участия исправительных учреждений с целью поиска заказов в закупках, проводимых конкурентными способами, является обязанность заказчика в отдельных случаях ограничивать круг участников закупки. В соответствии с положениями статьи 30 Федерального закона № 44-Ф3 государственные и муниципальные заказчики обязаны проводить не мене 15 \% от совокупного годового объема закупок у субъектов малого предпринимательства и социально ориентированных некоммерческих организаций (СМПиСОНО). С целью реализации данной обязанности заказчики устанавливают соответствующие ограничения на допуск к участию в закупках. Учреждения уголовно-исполнительной системы, не имеющие статуса СМПиСОНО, не обладают возможностью принять участие в такой закупке.

При этом законодатель устанавливает только минимальный объем закупок у СМПиСОНО, что дает государственным муниципальным заказчикам возможность фактически закупать у данной категории организаций значительно больший объем товаров, работ и услуг, вплоть до $100 \%$ от совокупного годового объема закупок.

Таким образом, рассматриваемая норма закона создает предпосылки для необоснованного ограничения объема закупок, в которых исправительные учреждения могут принять участие.

Необходимо рассмотреть несколько вариантов возможных решений данного вопроса. Во-первых, с учетом выполнения важнейшей социальной миссии по перевоспитанию и исправлению лиц, допустивших противоправное поведение, и, таким образом, по предотвращению совершения ими новых преступлений представляется справедливым включение исправительных учреждений в перечень категорий организаций, у которых государственные и муниципальные заказчики обязаны закупать продукцию в пределах установленного законом объема. Это позволит учреждениям пенитенциарной системы принимать участие в закупках, проводимых конкурентными способами, вне зависимости от решения заказчиков об установлении ограничений на допуск к участию. Исследователями предлагается также отдельно определить минимальный объем закупок, осуществляемых у учреждений уголовно-исполнительной системы, в виде доли от совокупного годового объема закупок заказчика. По мнению автора, соответствующая норма закона, с одной стороны, сохранила бы действующие меры поддержки субъектов малого предпринимательства и социально ориентированных некоммерческих организаций, а с другой обеспечила бы дополнительное стимулирование государственных и муниципальных заказчиков на размещение заказов в исправительных учреждениях.

Наконец, очевидно, что при проведении закупки заказчик будет преследовать интерес скорейшего получения требуемого товара. Анализ информации о государственных и муниципальных закупках, размещенной в Единой информационной системе в сфере закупок за период с 01.01.2020 по 01.10.2020, показал, что срок поставки товаров, производство которых наиболее широко осуществляется пенитенциарными учреждениями (это несложные изделия и конструкции из металла, корпусная мебель, постельное белье и принадлежности и так далее), редко превышает 20 дней с момента заключения контракта, часто составляет от пяти до 20 дней, 
в отдельных случаях заказчики устанавливают требование о поставке товара в течение двух - пяти дней.

Исправительные учреждения имеют статус казенных и, соответственно, обязаны в закупочной деятельности руководствоваться требованиями Федерального закона № 44-Ф3. Необходимость проводить процедуру закупки в полном соответствии с нормами Федерального закона № 44-Ф3 лишает учреждения пенитенциарной системы мобильности и гибкости при выборе поставщиков сырья и материалов для выполнения заказов, что имеет решающее значение в условиях устанавливаемых заказчиками требований о сроках поставки готовой продукции.

Производство продукции в исправительных учреждениях обладает своей спецификой. В частности, выпуск готовой продукции осуществляется уже в рамках заключенного контракта или договора. Риск заморозки бюджетных средств, связанный с изготовлением продукции без документально подтвержденной перспективы ее реализации, исключает формат производства «на склад».

В связи с этим в срок поставки готовой продукции входит как время на поиск, закупку и отгрузку сырья и материалов, так и затраты времени на осуществление технологических операций по непосредственному изготовлению и доставке готовой продукции до заказчика.

Равенство возможностей с негосударственными производителями в поле конкуренции за получение заказа может быть обеспечено за счет введения преимуще- ства, аналогичного действующему в отношении предложенной исправительными учреждениями цены контракта, но уже связанного со сроком поставки. Законодательное закрепление обязанности заказчика установить для победившего в закупке исправительного учреждения срок поставки продукции, превышающий, к примеру, на 10 дней срок поставки, указанный в извещении о закупке, позволит компенсировать наложенные законодательством ограничения на проведение пенитенциарными учреждениями закупок.

Итак, в настоящее время участие исправительных учреждений в закупках, проводимых конкурентными способами, как инструмент поиска заказов для привлечения осужденных к труду, несмотря на установленные законодателем преимущества, может использоваться лишь ограниченно в связи с рассмотренными выше проблемами. Решение каждой из них в отдельности или выработка комплексного решения позволит сбалансировать конкурентные возможности производственного сектора пенитенциарной системы, обеспечить равенство возможностей с негосударственными производителями и поставщиками. В конечном итоге обеспечение успешного использования исправительными учреждениями механизма участия в закупках, проводимых конкурентными способами, позволит привлечь дополнительные заказы, вовлечь в трудовую деятельность большее число лиц, осужденных к лишению свободы, и повысить эффективность работы по погашению вреда, причиненного преступлениями. $\diamond$

1. Уголовно-исполнительный кодекс Российской Федерации от 08.01.1997 № 1-Ф3 (ред. от 23.11.2020, с изм. от 28.12.2020). Доступ из СПС «КонсультантПлюс».

2. Об учреждениях и органах, исполняющих уголовные наказания в виде лишения свободы : закон Рос. Федерации от 21.07.1993 № 5473-I (ред. от 27.12.2019). Доступ из СПС «КонсультантПлюс». 
3. О контрактной системе в сфере закупок товаров, работ, услуг для обеспечения государственных и муниципальных нужд : федер. закон Рос. Федерации от 05.04.2013 № 44-Ф3 (ред. от 30.12.2020). Доступ из СПС «КонсультантПлюс».

4. Об утверждении перечня товаров (работ, услуг), производимых (выполняемых, оказываемых) учреждениями и предприятиями уголовно-исполнительной системы, закупка которых может осуществляться заказчиком у единственного поставщика (подрядчика, исполнителя) : пост. Правительства Рос. Федерации от 26.12.2013 № 1292 (ред. от 27.06.2016). Доступ из СПС «КонсультантПлюс».

5. О порядке предоставления учреждениям и предприятиям уголовно-исполнительной системы преимуществ в отношении предлагаемых ими цены контракта, суммы цен единиц товара, работы, услуги : пост. Правительства Российской Федерации от 14.07.2014 № 649 (ред. от 27.07.2019). Доступ из СПС «КонсультантПлюс».

6. Антонов В. И. Особенности участия учреждений уголовно-исполнительной системы Российской Федерации в государственных и муниципальных закупках // Ведомости уголовно-исполнительной системы. 2020. № 8 С. 6.

7. Иванова А. Н., Шевченко К. В. Преимущества учреждениям и предприятиям уголовно-исполнительной системы в закупках // Вестник Томского института повышения квалификации работников ФСИН России. 2019. № 1. С. 39.

8. Антонов В. И. Особенности участия учреждений уголовно-исполнительной системы … C. 7.

1. The Criminal and Executive Code of the Russian Federation of 08.01.1997 No. 1-FZ (version of 23.11.2020, as amended on 28.12.2020). Access from Legal Reference System «Consultant Plus».

2. On Institutions and Bodies Executing Criminal Sentences of Imprisonment : Law of the Russian Federation of 21.07.1993 No. 5473-I (as amended on 27.12.2019). Access from Legal Reference System «Consultant Plus».

3. On the contractual system in the sphere of procurement of goods, work and services to meet state and municipal needs : Federal Law of the Russian Federation of 05.04.2013 No. 44-FZ (as amended on 30.12.2020). Access from Legal Reference System «Consultant Plus».

4. On the approval of the list of goods (works, services) produced (performed, provided) by institutions and enterprises of the penal system, the procurement of which can be carried out by the customer from a single supplier (contractor, performer) : Ordinance of the Government of the Russian Federation of 26.12.2013 No. 1292 (as amended on 27.06.2016). Access from Legal Reference System «Consultant Plus».

5. On the procedure for granting advantages to institutions and enterprises of the penal system in relation to the contract price they offer, the total of prices for units of goods, work, services : Ordinance of the Government of the Russian Federation of 14.07.2014 No. 649 (as amended on 27.07.2019). Access from Legal Reference System «Consultant Plus».

6. Antonov, V. I. (2020) Specific features of participation of the Russian Federation penal system institutions in state and municipal procurement // Bulletin of the penal system. 8, 6.

7. Ivanova, A. N., Shevchenko, K. V. (2019) The advantages of institutions and enterprises of the penal system in the procurement // Bulletin the Tomsk institute of advanced training of employees the Federal Penal Service of Russia. 1, 39.

8. Antonov, V. I. Features of participation of institutions of the penal system ... p. 7. 
АВТОМОБИЛЬ, МОТОЦИКЛ

ИЛИ ДАЖЕ КАТЕР - ВОЗМОЖНО

ВСЁ С АВТОКРЕДИТОМ

ВТБ СО СТАВКОЙ ОТ 0,1\%

\section{$\equiv_{\text {ВТБ }}$}

\section{ОСОБЫЕ УСЛОВИЯ КРЕДИТОВАНИЯ}

\section{на покупку автомобилей и недвижимости для сотрудников ФСИН России от Банка ВТБ}

Для сотрудников ФСИН России предлагаются особые возможности по приобретению авто и мототехники или жилья в рамках совместной программы ФСИН России и Банка ВТБ - «Корпоративный клиент ВТБ. Ипотечное и автокредитование» (далее - Программа).

Сотрудник ФСИН России, вне зависимости от того, получает он заработную плату на карту Банка ВТБ или нет, может подать заявку на получение автокредита на особых условиях для корпоративных клиентов. Помимо специальной программы на приобретение нового автомобиля для крупных корпоративных клиентов «Автогигант» по ставке 0,1\% (при условии оформления страхования транспортного средства на срок кредита), сотрудники ФСИН, имеющие зарплатную карту ВТБ, получат дополнительные скидки и по другим программам, например, по программе «Беззалогового автокредитования». Такой автокредит - это просто деньги, на покупку совершенно любой техники, даже без колёс. По данной программе можно купить не только автомобиль с пробегом у частника, но и мототехнику, лодку, трактор или заказать автомобиль на иностранном аукционе.

Напомним, что ставка на покупку новостройки по госпрограмме 2020 в Банке ВТБ снижена, льготные условия действуют до 1 июля 2021². Дополнительно для сотрудников ФСИН действуют специальные условия ипотечного кредитования как на покупку нового жилья, так и для рефинансирования ранее полученного кредита. Подробнее узнать об условиях ипотечного кредитования и предложениях, предоставляемых в рамках Программы (от застройщиков, агентств недвижимости, автопроизводителей и других партнёров Банка ВТБ) можно в электронном каталоге. Для удобства сотрудников ФСИН в каталоге указаны контакты персональных менеджеров Банка, обращайтесь к ним для получения консультации, в случае если вы уже определились с программой - подать заявку можно в электронном виде на сайте Банка.

«Банк ВТБ на протяжении многих лет сотрудничает с ФСИН России, и мы рады предложить работникам организации комплекс специальных услуг и сервисов в рамках программы «Корпоративный клиент ВТБ. Ипотечное и авто-кредитование», - подчеркнул заместитель руководителя Департамента розничного бизнеса - вице-президент Банка ВТБ Евгений Дячкин. - Участие в Программе позволит существенно сэкономить время и средства сотрудников ФСИН России на всех этапах приобретения жилья или автомобиля, мы планируем и дальше расширять список предложений и преференций, предлагаемых в рамках Программы. Мы хотим, чтобы сотрудники ФСИН России знали, что с Банком ВТБ - удобно, быстро и выгодно!».

1000 БВонок По России

88001002424 / VTB.RU
Для просмотра электронного каталога в рамках Программы сотруднику ФСИн России необходимо отсканировать нижеприведенный QR-код с помощью своего мобильного устройства

${ }^{1}$ Базовая процентная ставка 9,4\%. Ставка снижается при оформлении заёмщиком личного страхования, страхования транспортного средства на срок кредита или карты «Автолюбитель» на 3,5\%, 3,9\% и 1,9\% соответственно (ставка в предложении с учётом оформления всех указанных услуг). Все дисконты суммируются, при наличии. Требования к страховым компаниям на vtb.ru. Сумма кредита до 7 млн руб., срок 12-84 мес., первый взнос от $20 \%$, валюта - рубли РФ. Условия действительны на 17.05.2021.

2 Ипотека по сниженной ставке в рамках программы «Ипотека с господдержкой 2020» (при условии комплексного страхования). Срок заключения кредитного договора до 01.07.2021 (включительно). Необходимо соответствовать требованиям госпрограммы и банка, включая требования к приобретаемой недвижимости. Условия действительны на 17.05.2021г.

Банк ВТБ (ПАО) оказывает исключительно банковские услуги. Банк вправе отказать в предоставлении кредита без объяснения причин. Банк предоставляет кредит в случае, если заёмщик (созаёмщик/поручитель, при наличии) соответствует требованиям госпрограммы и Банка и предоставил полный пакет необходимых документов. Банк ВТБ (ПАО). Генеральная лицензия Банка России №1000 


\section{ПОДПИСКА- 2021}

\section{Только у нас - все важнейшие пенитенциарные новости из первых уст!}

Если вы хотите быть в курсе событий, происходящих в уголовно-исполнительной системе страны, желаете знать мнение видных государственных и общественных деятелей, интересуетесь,

что собой представляет УИС сейчас и какой она будет в ближайшем будущем, выписывайте и читайте пенитенциарные издания: журналы «Преступление и наказание», «Ведомости уголовно-исполнительной системы» и газету «Казённый дом»!

\section{Стоимость внутриведомственной подписки на второе полугодие 2021 года:}

шесть номеров журнала «Преступление и наказание» - 420 руб.; шесть номеров журнала «Ведомости уголовно-исполнительной системы» - 408 руб.; двенадцать номеров газеты «Казённый дом» - 312 руб.

Никаких дополнительных расходов, в том числе на оплату услуг почты, подписчики не несут. Выписанные на служебный адрес издания будут поступать в узлы связи, обслуживающие учреждения УИС.

В соответствии с условиями внутриведомственной служебной подписки средства на названные издания учреждения и органы УИС направляют на расчетный счет Объединенной редакции ФСИН России. В платежных поручениях следует указывать наименование и адрес отправителя, количество оплаченных экземпляров изданий
и почтовый адрес того учреждения УИС, в которое они должны поступить.

РЕКВИЗИТЫ ФКУ Объединенная редакция ФСИН России для оформления внутриведомственной подписки:

УФК по г. Москве (федеральное казенное учреждение «Объединенная редакция» Федеральной службы исполнения наказаний, л/с 04731398800), ИНН 7712106779, КПП 774301001, ОКТМО 45336000,

Банк получателя: $\$$

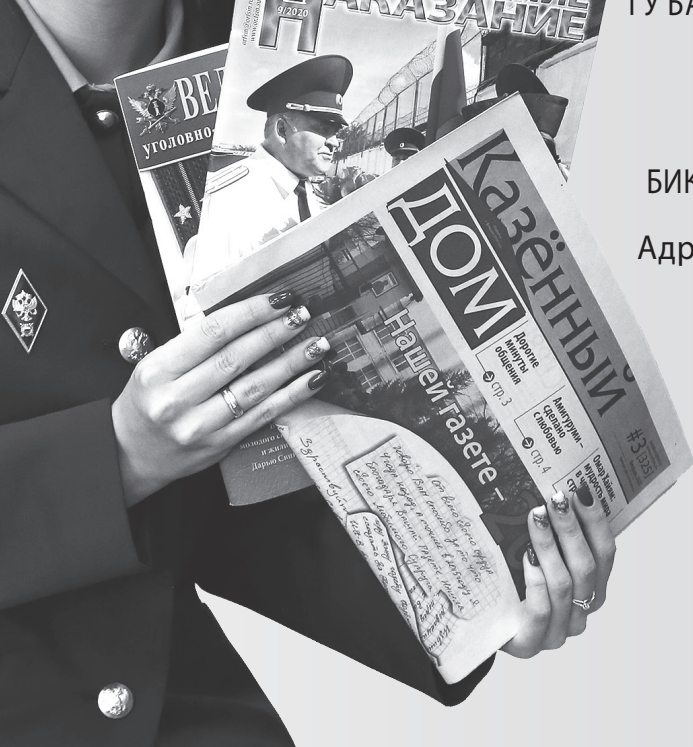

ГУ БАНКА РОССИИ ПО ЦФО//УФК ПО Г. МОСКВЕ г. Москва

Номер счета: 03100643000000017300 Корр. счет: 40102810545370000003 БИК 004525988, КБК 32011301991010200130 Адрес: 125130, Москва, ул. Нарвская, д. 15а.

Оформить подписку на наши издания можно также в отделениях и узлах связи по объединенному каталогу «Пресса России», каталогу агентства «Урал-Пресс».

ОБРАЩАЕМ ВНИМАНИЕ учреждений и органов уголовно-исполнительной системы:

денежные средства за выписанные экземпляры изданий должны поступить

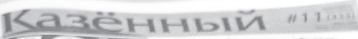
на расчетный счет 는 트난 Объединенной редакции ФСИН России 8) НЕ ПОЗДНЕЕ 15 июня 2021 года! 